\title{
In foro solitudo \\ Roman Elections and the Time of Cinna
}

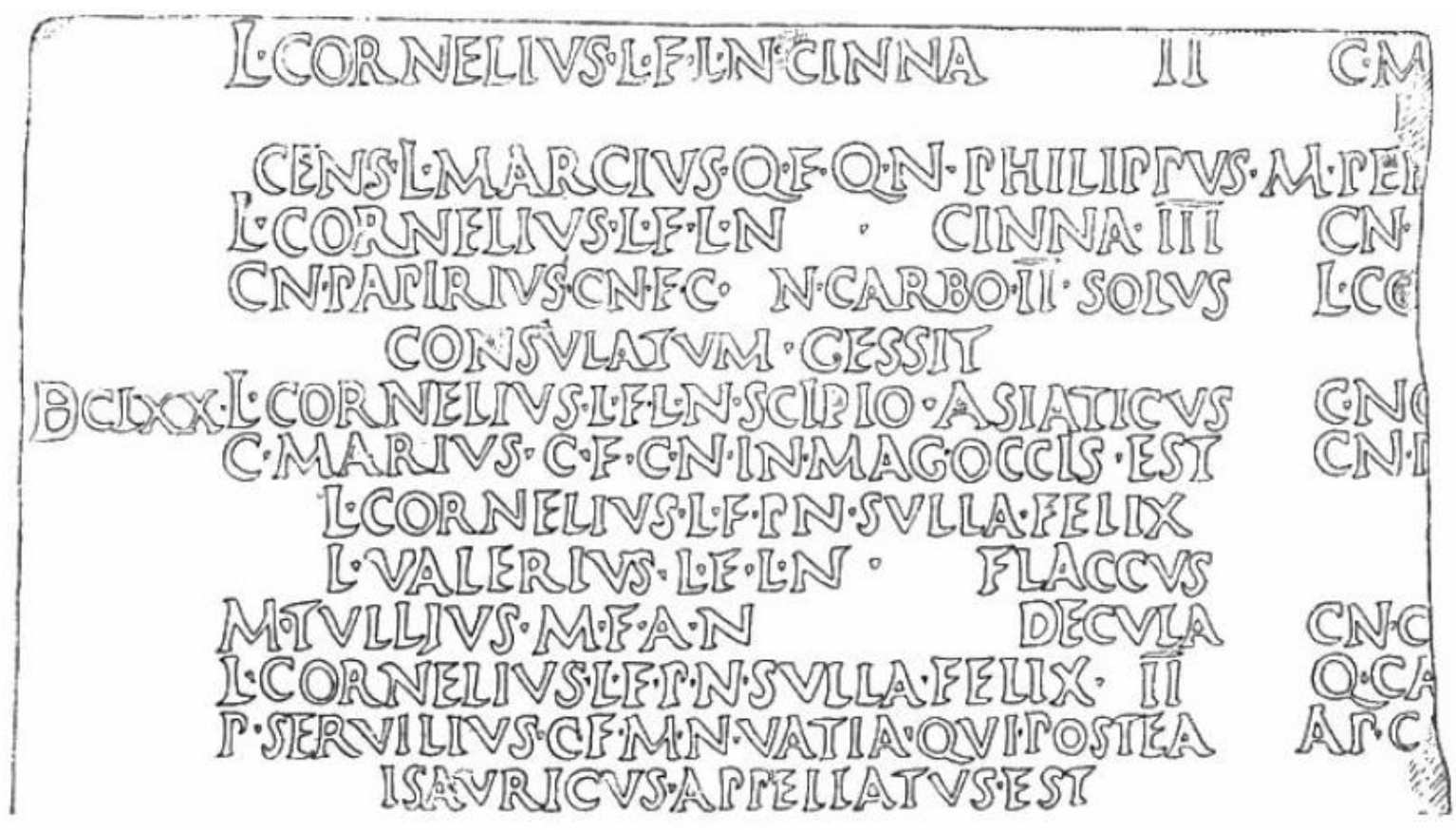

\section{Tim Smith}

Thesis submitted to Victoria University of Wellington in fulfilment of the requirement for the degree of Master of Arts in Classics 
Cover illustration from Degrassi's illustration of the Fasti Consulares Capitolini $(1947,54)$. 


\section{CONTENTS}

$\begin{array}{ll}\text { Abstract } & 2\end{array}$

$\begin{array}{ll}\text { Acknowledgements } & 3\end{array}$

Introduction: Irregular Elections in the Roman Republic 5

Chapter One: The Rise of Cinna $\quad 13$

Chapter Two: Terror and the Questionable Comitia for 86

Chapter Three: The Roman Constitution, 86-82 50

Conclusion: Enforced Tranquillity $\quad 74$

$\begin{array}{ll}\text { Bibliography } & 76\end{array}$ 


\begin{abstract}
The aim of this thesis is to provide a constitutional history of the mysterious years in the $80 \mathrm{~s}$ B.C. when L. Cornelius Cinna was re-elected to the consulship on four consecutive occasions. Further irregularities abounded in this period, raising the question of how Rome's annual elections were conducted in this period. A large amount of the surviving literature is either biased or uninformed on such matters. As a direct result, few have attempted to interpret the role of Rome's comitia, its voting assemblies, in this period in any sufficient detail. This survey aims to fill this lacuna.

From close inspection of the scattered evidence, it may be argued that Rome's comitia did indeed play a role in the so-called Cinnae dominatio, despite the hoarding of high magistracy by just a handful of individuals. There were laws designed to prevent this domination: men were theoretically allowed to hold the consulship once (at least within a tenyear period); continuatio was forbidden. This study sets out to investigate how Cinna's continuatio came to be tolerated. Some scholars have attempted to explain away this irregularity as a simple product of the turbulent times. After all, electoral irregularities did indeed increase in frequency during times of existential crisis. But Cinna's elections do not adequately harmonize with any precedent in Rome's history.

This study begins with a survey of the Roman constitution in the years leading up to the Cinnae dominatio. The years 91 to 87 were marred by almost continuous warfare in Italy and abroad. However, despite attempts at attaining the consulship by a couple of theoretically ineligible candidates, Rome's electoral restrictions remained robustly in place. All of this changed in late 87 when Cinna marched on Rome with a large army: many political opponents were murdered or exiled; Cinna assumed the consulship soon after. The process by which he became consul has been the subject of great controversy. Although it would seem that comitia were called, the process was irregular. These irregularities would continue even after Cinna died in 84 , coming to an end in the years following Sulla's restoration of the traditional republic after 81 .
\end{abstract}




\section{ACKNOWLEDGEMENTS}

There are several people without whose support and encouragement I would not have been able to embark on this project. First, I ought to thank my supervisor Prof. Jeff Tatum. His advice was unceasingly incisive and provoked numerous additional questions which I researched with enormous pleasure. Looking back on the last twelve months, I am astonished by how much I have learned, thanks to no small measure to Prof. Tatum's guidance. Relatedly, I am immensely grateful to the Marsden Fund and the Victoria Scholarships Office for funding this project as part of Prof. Tatum's funded research on the Roman People. I am honoured to have been chosen to play a small part of this research. Thank you, Jeff.

There are many people to whom I am greatly indebted. My supervisor from an earlier project, Dr Marco Sonzogni, was always supportive of my change in direction, and his distractions with other exciting research projects were always welcome. I must also thank several members of the Classics programme at Victoria University, chiefly Prof. Arthur Pomeroy and Dr Simon Perris, for their incisive and challenging comments. I am also grateful to Dr Perris for his continued faith in me as a tutor and (sort-of) editor. I have thoroughly enjoyed working for him over the last two years. I must also thank Dr Diana Burton for providing me with an excellent foundation in the Greek language. I still have much work to do, but her teaching was of inestimable value for this thesis.

Special thanks go to Dr David Rafferty for his advice per litteras and viva voce during the ASCS conference. It is always exciting to meet someone even more passionate about the subject than I. My office colleagues James Hugman, Stacey Wellington, Liam Grandy, Alice Fairley, and Melanie Teahan deserve credit for helping me to keep a degree of sanity during the research and writing process.

I am obliged to the team at Student Learning, not least Marie Paterson, Ann Pocock, and Jan Stewart, for their flexibility and emotional support throughout the process. I very much look forward to working with them more in the future.

Above all else, I must thank those closest to me for their unerring love and support. This thesis, as with my first, is dedicated to those whom I love most in the world: Mum, Dad, Anna, Kele, and Nikki.

Quel sorriso m'ha salvato da pianti e da dolori 


\title{
INTRODUCTION
}

\section{IRREGULAR ELECTIONS IN THE ROMAN REPUBLIC}

\author{
Audieram ex sapientissimo homine atque optimo civi et viro, $Q$. Catulo, non \\ saepe unum consulem improbum, duo vero numquam excepto illo Cinnano \\ tempore fuisse.
}

('I had heard it from the wisest and foremost of citizens and men, Q. Catulus, that it was seldom that there would be one wicked consul in office, and never two - except during the time of Cinna, of course!') ${ }^{1}$

The Cinnanum tempus, the years in the 80s B.C. during which L. Cornelius Cinna and his close associates monopolized Rome's higher magistracies, remains a highly controversial period. ${ }^{2}$ Between 87 and 82, the Roman consulship was held by just a small handful of men while their political enemy, L. Cornelius Sulla, was absent fighting the Mithridatic War in Greece and Asia. There is no scholarly consensus on how elections were conducted at Rome in this period: the evidence supplied by our sources is frequently contradictory and frustratingly lacking in detail.

The basic facts are clear: Cinna was elected to the consulship on four consecutive occasions from 87 to 84 . His colleague Cn. Papirius Carbo gained three consulships in four years. This exceptional continuation of office followed a series of catastrophic wars in Italy, during which Rome's Italian allies had rebelled; shortly after, Rome was gripped by civil war. Cinna, together with Rome's pater patriae C. Marius, the hero of the Cimbric Wars of the 100s, marched on Rome and killed Cinna's colleague in the consulship for 87, Cn. Octavius. ${ }^{3}$ Many distinguished Romans were killed, exiled, or forced to flee. This act ushered in a peculiar period in Rome's history during which a small coalition of men held enormous power over the organs of government, an eventuality which Rome's political system was designed to prevent. Although this period would be later recognized as triennium sine armis, there were gross contraventions of electoral rules. ${ }^{4}$ One of the critical questions that this essay raises, then, is how certain individuals were able to attain such unprecedented power in a system constructed to place limits on individual influence.

\footnotetext{
${ }^{1}$ Cic. Red. sen. 9. All translations in this work are the author's.

${ }^{2}$ All dates from antiquity are henceforth B.C. unless otherwise stated.

${ }^{3}$ See Cic. Rab. 27 for Cicero's flattering sobriquet for Marius.

${ }^{4}$ Cic. Brut. 308.
} 
A few studies have been carried out in the last century chiefly concerning the mysterious career of Cinna. ${ }^{5}$ Some attempts, too, have been made to rescue his reputation from its almost universal blackening in antiquity. This hostile tradition stems from the self-evident fact that Sulla ultimately won, his propaganda present in almost every historical account of the period preserved to us. ${ }^{6}$ Cinna was condemned as cruel and tyrannical, his multiple consulships dismissed as a dominatio. Such bias naturally makes any historical reconstruction problematic. Not that all of our sources are in Sulla's thrall: Sulla, too, was reviled for his actions upon his return to Rome in $82 .^{7}$ It may therefore be somewhat extreme to argue that 'Cinna has effectively been erased from history by Sulla' and defeatist to conclude that 'it is now impossible to write a history of Cinna in any detail'. ${ }^{8}$ As this study will show, much can be squeezed out of the scattered evidence to reconstruct a coherent picture of the political situation in Rome during Sulla's absence.

In light of our heavily anti-Cinnan evidence, some modern scholars have been unable to resist the temptation of moralizing in favour of the defeated party. As Erich Gruen puts it, 'the reaction to orthodoxy can be over-enthusiastic'. ${ }^{9}$ Thomas Mitchell frames the debate aptly:

The Cinnae dominatio ... [is] a controversial era vilified by a hostile ancient tradition heavily influenced by Sulla's memoirs, a tradition sometimes uncritically accepted by modern scholarship, sometimes scornfully rejected in impatient overreaction against flagrant bias. ... [But] the goals and actions of Cinna's government cannot be reduced to simple judgments of praise or blame. $^{10}$

This study will endeavour to avoid this dialectic. Ernst Badian's 1962 essay 'Waiting for Sulla' is the classic work in this tradition of historical character rehabilitation, though many others have proceeded in the same direction of exonerating Cinna from blame for the perturbations of the mid-80s. ${ }^{11}$

\footnotetext{
${ }^{5}$ See, e.g., Bennett 1923; Badian 1962b; Bulst 1964; Katz 1976b; Lovano 2002.

${ }^{6}$ See, e.g., Tatum 2011, 163-74.

${ }^{7}$ See, e.g., Cic. Cat. 3.24; Val. Max. 9.2.1; App. B Civ. 1.95-6.

${ }^{8}$ Flower 2006, 97; 2010, 93. Cf. Cic. Quinct. 70, though Cicero here inveighs against the violence of the historical period, not, as Flower (1996, 307 n. 29), claims, 'The time of Cinna' specifically. See, e.g., Rolin 1979, 578; Kinsey 1967, 64.

${ }^{9}$ Gruen 1968, 239. Cf. Katz 1976b, 547 n. 190, on the "“seesaw" effect' of modern moralizing accounts, wherein there is a 'tendency for Cinna's 'grades' to rise in proportion to the decline in Sulla's reputation'.

${ }^{10}$ Mitchell 1979, 78.

${ }^{11}$ Positive value judgements: Bennett 1923, 67; Badian 1962b, 55; Lovano 2002, 77; Mackay 2004, 127; 2009, 143. Flower 2010b, 79, contra.
} 
This study will raise quite different questions beyond simple rehabilitation and censure. Little work has been conducted directly on the role of comitia and the Roman People during the time of Cinna. ${ }^{12}$ All of our sources give the impression that there were irregularities at the ballot box during these years. One man should not be allowed to hold consulships repeatedly. The procedure by which Cinna and his colleagues ascended to the consulship is not immediately clear. Livy's Periochae at one point claims that elections were cancelled outright, ${ }^{13}$ while other sources seem to indicate that traditional procedures were by and large followed. This discrepancy has, understandably, been the source of much confusion.

Let us begin with a brief discussion of how the Roman elections were supposed to work. There were clear restrictions on the holding of magistracies in the Roman republic. The consulship in Rome was awarded to two men per year. Election to the consulship was the height of political achievement, and such a glory would ennoble one's family forever. Just one consulship would be sufficient for this. Under regular circumstances, comitia, Rome's public assemblies, were called annually to elect the city's officials. Though the system was generally weighted in favour of the votes of Rome's upper classes, all male Roman citizens theoretically had the capacity to vote for their preferred candidates in these assemblies. As a direct consequence, elections were frequently highly competitive, with more eligible and willing candidates than positions available. An unsuccessful campaign would be the subject of great embarrassment, connoted explicitly by the Roman term for defeat at the ballot box: repulsa.

Certain electoral rules, however, narrowed the number of eligible candidates, and generally restricted high office to men of noble birth and from great aristocratic families. ${ }^{14}$ It was theoretically illegal, at least for a time, to hold the consulship more than once, lest an individual gain too much power. At the very least, ten years theoretically had to pass between consulships. There were further rules: one had to be advanced in years to be eligible for the consulship; there had to be a two-year gap between magistracies; and one had to hold the praetorship before being eligible for the consulship. ${ }^{15}$ And yet, iterations and continuations of the consulship, as well as other irregularities, did occur from time to time. The infrequency,

\footnotetext{
${ }^{12}$ Lovano 2002, the most recent prosopographical study of Cinna, devotes just two pages (68-9) on the functioning of comitia from 87 to 82, concluding, with little conviction and minimal evidence, that 'there are indications that the Popular Assemblies continued to operate rather normally under the Cinnans.' Cf. Badian 1962b, 58 n. 12.

${ }^{13}$ Liv. Per. 80.

${ }^{14}$ See, e.g., Giovannini 2015, 24-7, 181-5, for a broad overview.

${ }^{15}$ Age restrictions were laid down in the lex Villia Annalis of 180: Liv. 40.44.1. Theoretically, one had to be fortytwo for the consulship (Cic. Phil. 5.48), or forty for patricians if we believe Badian 1959, 88. Cf. Astin 1958, 1819.
} 
unconventionality, and apparent illegality of such repetitions render these exceptions to the rule all the more remarkable.

When were these restrictions put in place? There is no precise evidence stipulating the existence of a strictly regimented cursus honorum before Sulla's reforms of $81 .{ }^{16}$ But one glance at the fasti is enough to indicate that this was by no means a Sullan innovation. ${ }^{17}$ Attaining multiple consulships before the passing of ten years was contra exempla atque instituta maiorum before Sulla's reforms. Any hint of regnum was at odds with the Roman notion of res publica. Continuatio (consecutive re-election to the same magistracy), then, was particularly unnerving. ${ }^{18}$ If an individual hoarded a higher magistracy, it limited political opportunity for rival aristocrats; competition among the aristocracy was an important component of electoral contests. ${ }^{19}$

There were circumstances under which these rules could be bent: electoral custom was subject to 'flexible implementation'. ${ }^{20}$ This was especially the case during wartime: the Hannibalic War witnessed frequent iterations and continuations in the consulship. ${ }^{21}$ But this was an exceptional time. A.E. Astin has observed that 'the series of contradictory cases comes to an abrupt stop in 208'; iterations dry up. ${ }^{22}$ Indeed, there was only one full iterated consulship within the decennium between the end of the Second Punic War (201) and the second consulship of Marius (104). Following the Hannibalic War, then, electoral rules were tightened. ${ }^{23}$ By the $150 \mathrm{~s}$, there was a ban on iteratio altogether. ${ }^{24}$ There can be little doubt, then, that the repeated consulships of Cinna in the 80s were exceptional and, at first blush anyway, illegal.

\footnotetext{
${ }^{16}$ Detailed in App. B Civ. 1.100 .

${ }^{17}$ The ultimate origin of Roman electoral rules has been the subject of fierce debate. The debate centres on the veracity of the lex Genucia of 342 reported in Liv. 7.42.2. See, e.g., Billows 1989; Brennan 2000, 67 and 273 n. 49; Hölkeskamp 1987, 126-9; Beck 2005, 96-105. Despite Appian's statement that Sulla vó

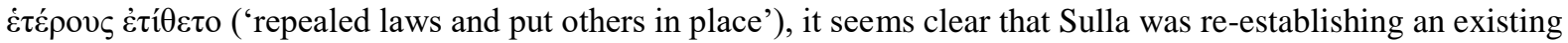
law, as was familiar practice in Roman law-making; the inclusion of the quaestorship in the cursus honorum, however, may have been innovative. Cf. Sumner 1973, 7-10; contra Develin 1979, 85.

${ }^{18}$ In general, see Oakley 1998, 229; Greenidge 1901, 185-9.

${ }^{19}$ See, e.g., Rosenstein 1993, 313 et passim.

${ }^{20}$ Hölkeskamp 1993, 23.

${ }^{21}$ Liv. 27.6.7.

${ }^{22}$ Astin 1958, 20 n. 6. Jehne 2011, 227, suggests that the dramatic rise in iterations during the Hannibalic War precipitated the desire to restrict them immediately afterwards.

${ }^{23}$ Astin 1958, 27: the opening two decades of the second century represent a veritable 'age of reform of the magistracies'. No ban on continuatio or iteratio is explicitly attested, making firm conclusions about the passing of legislation hazardous.

${ }^{24}$ Liv. Per. 56, traditionally dated to 151 (Rotondi 1922, 290-1; Malcovati 1955, 75). Plut. Mar. 12.1 appears to be unaware of this law, mentioning only the necessary ten-year gap between magistracies. Cf. Astin 1958, $20 \mathrm{n}$. 6; Valgiglio 1956b, 65-6.
} 
A handful of theoretically ineligible men stood for and were elected to the consulship in the second century. T. Quinctius Flamininus attained the consulship for 198 despite being just 31 years old. ${ }^{25}$ Q. Fulvius Flaccus attempted (unsuccessfully, owing to the resistance of the Senate) to stand for the suffect praetorship of 184, despite already being curule aedile for the year. ${ }^{26}$ C. Marcius Figulus and P. Cornelius Scipio Nasica, briefly colleagues in the consulship for 162 , were elected to the consulships of 156 and 155 respectively. ${ }^{27} \mathrm{M}$. Claudius Marcellus was elected to a third consulship for 152 , three years after his second. ${ }^{28}$ This seemingly led to the complete ban of iteratio a year later. ${ }^{29}$ And Scipio Aemilianus was elected to two unconventional consulships: for the first in 147 he was theoretically too young and had never been praetor, ${ }^{30}$ the second for 134 contravened the recent law against iteratio. ${ }^{31}$ There is not the room here to discuss the circumstances of these elections in full. Suffice it to say, all of these elections were controversial, and were the cause of much envy and chagrin across the aristocracy. But the People's will was (almost) inviolable.

The most obvious precedent for Cinna's continuatio, however, was that of $\mathrm{C}$. Marius, Cinna's future colleague, twenty years earlier. Marius' continuatio from 104 to 100 is a vivid example of the People expressing their voluntas through the ballot box to choose a theoretically ineligible candidate. The Cimbri and Teutones presented an existential threat to Roman Italy. ${ }^{32}$ The immensely popular Marius, Rome's war hero, was elected repeatedly by the people to address this threat. Although his violation was theoretically $\pi \alpha \rho \alpha \grave{~ v o ́ \mu o v \varsigma, ~ h i s ~ e l e c t i o n ~ c o u l d ~}$ not be denied owing to the inviolable will of the people. As Plutarch tells us: $\tau$ ò $\delta \varepsilon v i \tau \varepsilon \rho o v$

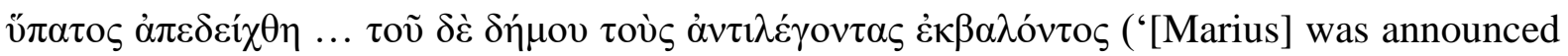
consul for a second time ... with the People rejecting any opposition'). ${ }^{33}$ And there was indeed

\footnotetext{
${ }^{25}$ Liv. 32.7.11; Plut. Flam. 2.1. Cf. Billows 1989, 122; Astin 1958, 26-8.

${ }^{26}$ Liv. 39.39.1-13; cf. Earl 1965, 330-1; Hall 1972, 35; Rampazzo 2005, 109-15.

${ }^{27}$ Val. Max. 9.3.2; Cic. Brut. 79. Cf. Astin 1967, 40: although they were removed from office owing to bad augurs, they still subsequently held consular status.

${ }^{28}$ See, esp., Astin 1967, 38-40. Cf. Develin 1979, 94 with n. 75, contra Calvert 1961, 22-3, who unpersuasively argues that the law against iteration applied only to one's second consulship.

${ }^{29}$ Liv. Per. 56; Rotondi 1922, 290-1; Astin 1958, 20 n. 6; De Martino 1960, 369 n. 29; Scullard 1973, 234.

${ }^{30}$ App. Pun. 112, Liv. Per. 50, Cic. Phil. 11.17, Vell. Pat. 1.11.2-3. Develin 1978a, 484-8, and Rampazzo 2005, 107-9, persuasively argue that Scipio was never a candidate for this election, contra Staveley 1972, 146, 249-50 nn. 260-2; Astin 1967, 66. Nevertheless, the confidence of the former scholars that the People's will was spontaneous and that Scipio never canvassed for the consulship seems unjustified. See Astin 1967, 64, and Tatum 2013 , 138, for a cogent critique of this view. Grieve 1985, 283-6, provides an original albeit highly controversial viewpoint on this election which has found little favour.

${ }^{31}$ App. Ib. 84; Liv. Per. 56; Val. Max. 2.7.1, 8.15.4; Cic. Amic. 11; 'Plut.' Apophth. Scip. Min. 15.

${ }^{32}$ Liv. Per. 65, 67. Cf. Plut. Mar 11.1 with Valgiglio 1956b, 56-8, on the direct link between Marius’ second election and the foreign threat.

${ }^{33}$ Plut. Mar. 12.1.
} 
some opposition. ${ }^{34}$ Marius' elections for 102 and 100 were highly competitive, with the consul resorting to underhand tactics to secure his re-election. ${ }^{35}$ Many members of the upper classes would have likely been tacitly hostile towards Marius' consulships; but there was little they could do without appearing to place their own personal interests ahead of those of the republic. ${ }^{36}$

In addition, Marius himself was the presiding magistrate. The purpose of the presiding magistrate, filled by one of the consuls for the previous year, was to announce the winners of the election and accept candidates' formal announcement of candidature, their professio. Theoretically, the presiding magistrate could deny ineligible candidates the right to run for office. ${ }^{37}$ Professio was, at the very least, customary at this time in the republic; in any case, it was a very public procedure and a critical part of one's canvassing. ${ }^{38}$ Denial was uncommon, but not unheard of. In this instance, however, despite the stigma against presiding over one's own re-election (a natural product of Rome's aversion to any hint of regnum), no one was equipped to prevent his continuatio. Given Marius' popularity, and the apparent urgency of the military situation, the Roman Senate could do little more than sit on the sidelines.

The only way he could be thwarted was at the ballot box. ${ }^{39}$ Thus the paradox inherent in Roman law is revealed. It was theoretically illegal for a man to break these electoral rules, but if the electorate chose an ineligible candidate there were few options to prevent his ascension to office. The People's decision in the comitia was law. ${ }^{40}$ In theory, in addition to refusing to accept an illegal candidature, the presiding magistrate could step in to refuse to consider votes cast for the candidate. ${ }^{41}$ But Marius successfully navigated his way around these restrictions by taking advantage of the contradictions in Roman electoral law.

\footnotetext{
${ }^{34}$ Despite Cic. Prov. cons. 19 and Sall. Iug. 114.4. The former attempts to make a rhetorical point with Marius' exemplum; the latter is tinged with irony and foreboding (cf. Paul 1984, 258-9; Kraus \& Woodman 1997, 26-7; Scanlon 1987, 61). Neither account can be taken as proof of universal approval from 104 to 100.

${ }^{35}$ On 102: Plut. Mar. 14.1; 14.7; Yakobson 1999, 159; Passerini 1971, 48-50. On 100: Plut. Mar. 28.5, Liv. Per. 69. The Senate's offer of a premature triumph to Marius (Plut. Mar. 24.1) may be proof of the Senate's attempts to unseat Marius from the command (cf. Drogula 2007, 444).

${ }^{36}$ Rosenstein 1993, 318.

${ }^{37}$ On the power of the presiding magistrate and professio in general, see Staveley 1972, 146-7; Pina Polo 2011, 205 with n. 70; Linderski 1966, 523-6.

${ }^{38}$ For debate over when (or whether) professio became obligatory, see Earl 1965, 331; Develin 1978a, 484-8; Astin 1962, 252-5; Levick 1981, 378-88.

${ }^{39}$ Clear attempts were made in the elections for 100, when Q. Caecilius Metellus, the Senate's preferred candidate, ran against Marius. Plut. Mar. 28.5. Cf. Badian 1984, 121-2; Broughton 1991, 9; Evans 1987, 67-8.

${ }^{40}$ Liv. 7.17.12.

${ }^{41}$ The candidacy of C. Servilius Glaucia ( $p r .100$ ) for the consulship of 99, for instance, was refused (Cic. Brut. 224). The operative vocabulary for the presiding magistrate's acceptance of one's candidacy consists of the phrases rationem habere and accipere nomen, though there is debate as to whether these terms refer to the counting of votes alone (Earl 1965, 330-1; Hall 1972, 35; Rampazzo 2005, 109-15) or to acceptance of candidature as well (Staveley 1972, 210, 250-1 n. 266).
} 
With the end of Marius' continuatio, irregularities stop. No one (that we know of) would attempt to gain an irregular magistracy until the early $80 \mathrm{~s}$, and no one would be successful until Cinna was elected to his second consulship for 86. In sum, irregular candidacies could be tolerated under certain circumstances, generally during an existential crisis. $^{42}$

Cinna's continuatio must be understood in completely different terms from these earlier irregular elections. ${ }^{43}$ The circumstances in the $80 \mathrm{~s}$ were quite different. There were no barbarians at the gate and a good number of Rome's best men had died in the conflagration of 87 or fled the city. It has justly become unfashionable to discuss Roman politics in terms of factionalism and party politics: political alliances were ephemeral and seldom based on much more than mutual benefit and gratia. ${ }^{44}$ But the Cinnanum tempus was a unique period in which a small clique of individuals dominated domestic politics and political opponents were silenced or removed. Competition, one of the mainstays of the Roman republic, was curtailed in a way never previously seen. At the height of the Cimbric and Hannibalic Wars, men jostled for the summa laus. ${ }^{45}$ This study therefore seeks to trace the means by which Cinna cultivated support (or, at least, toleration) to be able to sustain his unique and unconstitutional continuatio, which Catherine Steel has not unfairly dubbed one of a handful of 'experiments in autocracy' ${ }^{46}$

The first chapter of this thesis will trace the political rise of Cinna, examining the comitia before his extraordinary second consulship. There were a couple of attempts at gaining irregular magistracies in the early 80s, but neither was successful. Roman constitutional norms remained largely intact until 87 . The civil war of 87 , however, represents a violent jolt that disturbed these norms. This chapter, then, traces the origins of this conflict, and examines the unique circumstances that effected the abandonment of basic republican principles. Chapter Two focuses expressly on Cinna's second election for 86 , one of the most controversial elections of the late republic. Livy's Periochae informs us that no comitia were called at all, and Cinna and Marius simply made themselves consuls. This section evaluates the likelihood of this claim, and attempts to recreate the procedure by which these men received the consulship. Chapter Three provides a constitutional history of the years 86 to 82 , during which

\footnotetext{
${ }^{42}$ Cf. Cic. Man. 60.

${ }^{43}$ Contra Badian 1962b, 57. Cf. Lovano 2002, 68.

${ }^{44}$ Cf. Brunt 1988, 449, 463. Likewise, it is important to resist the temptation of explaining the period in terms of class conflict. Cinna, for instance, is never referred to as popularis: see Katz 1976b, 535 n. 148; Duplá 2011, 286; Mouritsen 2017, 130.

${ }^{45}$ Rosenstein 1993, passim. Although Marius' continuatio certainly reduced opportunity (see Cic. Brut. 176 on the petitionis angustiae), the other consulship was highly sought after, and Marius was by no means at the head of a lasting or domineering faction (Badian 1958a, 203).

${ }^{46}$ Steel 2013, 124.
} 
Cinna, his friends, and his successors would dominate high magistracy until Sulla's ultimate victory in late 82. Comitia, I contend, were held during this period, but there were striking irregularities that set the Cinnae dominatio apart from any previous period of Roman history.

Elections during the Cinnae dominatio have been the source of much uncertainty. In his recent monograph on Cinna, Michael Lovano conceded that 'Cinna and Carbo stifled any potential rival candidates', which was doubtless true; he goes on to claim, however, that this 'would not have been an innovation in the politics of the Republic.' ${ }^{47}$ The latter claim needs revision. The Cinnae dominatio was an extraordinary period in the Roman republic during which competitive elections were done away with and high magistracy was dominated by a small clique of individuals. The republic was sine iure, sine dignitate. ${ }^{48}$ Even if the elections broadly followed the letter of the law, they were entirely removed from the spirit of the res publica.

${ }^{47}$ Lovano 2002, 68.

${ }^{48}$ Cic. Brut. 227. 


\section{CHAPTER ONE}

\section{THE RISE OF CINNA}

Little is known about Cinna's personal background. He was a patrician, and it is likely that he was the son of the consul of 127 of the same name, given the rarity of his cognomen. ${ }^{1}$ A passing mention by Cicero would suggest that he was praetor in 90 during the Social War. ${ }^{2}$ Beyond such fragments, we learn nothing about Cinna until his election to the consulship of 87 . In order to understand the political climate during the time of Cinna, however, we must first evaluate the conditions that foregrounded his repeated elections. The perturbations of the years 91 to 87 naturally must condition our interpretation of the Roman constitution during the Cinnanum tempus. Crucially, Rome's electoral rules were observed even in this highly perturbing period: despite a couple of attempts, no ineligible candidates were elected to the consulship until after the civil war of 87.

The 90s, a by and large peaceful decade, finished with a bang. In 91, Rome's Italian allies rose up in open revolt, seemingly as a result of the mysterious murder of the tribune who had sought to extend voting rights to the socii. ${ }^{3}$ The motives of the deceased tribune, M. Livius Drusus, are obscure. He promulgated an array of policies which avowedly seemed to benefit the Senate, the equites, the urban plebs, and the socii alike in different ways: to the Senate, he promised control of the courts; to the equites, he offered places in the Senate; and, to the urban plebs, he offered rural land and grain subsidies. ${ }^{4}$ And, of course, he took on the cause of the Italians who had no vote and no citizen rights. ${ }^{5}$ Rome had not seen such a bold social programme since the time of C. Sempronius Gracchus. But, with the exception of the plebs, he managed to attract the chagrin of all of the interested parties. ${ }^{6}$ As Arthur Keaveney puts it, 'in trying to please everybody he had pleased nobody or almost nobody. ${ }^{7} \mathrm{He}$ was murdered by

\footnotetext{
${ }^{1}$ On Cinna's patrician status, see MRR 1.507; Katz 1976b, 534 n. 147; Lovano 2002, 25; Linderski 2005, 228; contra Mommsen RF 1.114; Taglialatela Scafati 1995, 71-83; and the doubts of Rawson 1979, 336 n. 62.

${ }^{2}$ At the very least, he had been elected to the praetorship by 89: Cic. Font. 43; Liv. Per. 76. Cf. MRR 2.30.

${ }^{3}$ Vell. Pat. 2.15.1 makes this causative link. Despite Appian's assertion that the war started $\pi \alpha \rho \alpha \operatorname{\delta o} \xi o \varsigma$ (B Civ 1.34), it seems clear that 'growing allied restiveness' had developed over many decades, and it is possible that rebellion was being considered as early as 95 (see Keaveney 1987, 76-98 esp. 83 with n. 34; quoted at p. 87).

${ }^{4}$ Appian's account (B Civ 1.35-6) is concise but covers the broad details. See MRR 2.21-2 for further sources on Drusus' legislation, and Gabba 1994, 111-14, for general discussion.

${ }^{5}$ See Salmon 1967, 346, on the many grievances of the socii.

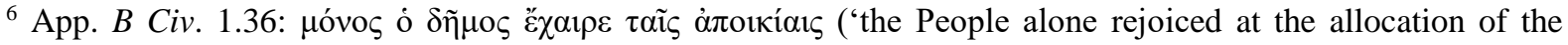
colonies').

${ }^{7}$ Keaveney 1987, 90.
} 
one of the disgruntled parties and, almost immediately, open warfare that had been brewing for some time broke out.

The allied rebellion, and the bloody Social War that stemmed from it, represented an existential crisis on a scale not seen for generations. Even during the Cimbric Wars of the 100s there had not been mobilized enemy armies in central Italy. It was a war of exceeding brutality. ${ }^{8}$ The Romans, having endured several ignominious defeats and witnessed the deaths of several senior figures, including the consul of 90 P. Rutilius Lupus, did not - perhaps could not achieve outright victory. ${ }^{9}$ The lex Iulia of 90 , promulgated by the surviving consul L. Iulius Caesar, offered citizenship to those who had not fought against Rome, or who stopped fighting immediately (thus granting some of the allies exactly what they had been struggling towards in the first place). ${ }^{10}$ Many Italians immediately stopped fighting, depleting the forces of the resisting Italians, who seemingly had much higher ambitions. After the deeply troubling campaigning season of 90 , the Romans took the initiative in 89 , with great success gained by the consul Cn. Pompeius Strabo and L. Cornelius Sulla; the former would celebrate a triumph for his successes in his consular year; the latter would be elected to the consulship of 88 on the back of his successes. ${ }^{11}$ Though the Social War continued the following year, the rebel forces had been much reduced in size and power. ${ }^{12}$ Many of the Italians had been granted citizenship, and were divided into an uncertain, but certainly minimal, number of new tribes. ${ }^{13}$

But Rome was quickly confronted with brand new problems, both at home and abroad. Mithridates of Pontus, capitalizing on the instability in Italy and the palpable unrest and dissatisfaction with Roman rule in the Greek East, declared war on Rome in late $89 .{ }^{14}$ Sulla, the newly elected consul for 88 , was assigned the command, by lot our sources tell us. ${ }^{15} \mathrm{We}$

\footnotetext{
${ }^{8}$ Flor. 2.6.11: nec Annibalis nec Pyrrhi fuit tanta vastatio ('there was no such devastation from either Hannibal or Pyrrhus'). Cf. Diod. Sic. 37.2.15. Salmon 1967, 345-6, however, judges that victory for the socii was always highly unlikely. Still, Keaveney 1987, 144, notes that 'the fear of annihilation hung over [the Romans] and they were obliged to fight for their very existence.'

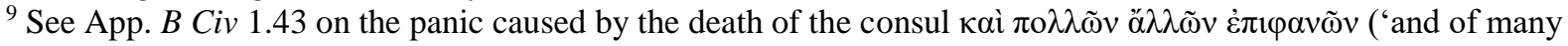
other aristocrats'). Cf. Salmon 1967, 354, and Keaveney 1987, 135-6, 142, on the troubling deaths of many aristocrats during this period.

${ }^{10}$ Or, as Salmon 1967, 360, terms it: 'concession of the original point at issue'. Cf. Cic. Balb. 21; Bispham 2007, 162-72; Rotondi 1922, 338-9; and Salmon 1967, 360-1, on the terms of the law.

${ }^{11}$ Cf. Flor. 2.6.14 on Strabo's triumph.

${ }^{12}$ Salmon 1967, 369-70.

${ }^{13}$ See Keaveney 1987, 178 n. 28, and Salmon 1967, 361-2 n. 4, and sources listed therein, for the disagreement on the number of tribes created. Our sources are App. B Civ. 1.49 (ten?) and Vell. Pat. 2.20 .2 (eight).

${ }^{14}$ App. Mith. 10-21 details the background and early engagements of the war. Cf. Vell. Pat. 2.18; Liv. Per. $77-$ 8. See Luce 1970, 190, and Badian 1958a, 231-2 n. 5 for the dating of the comitia and the assignation of the provincial command.

${ }^{15}$ Modern scholarship is deeply divided on the assignation of the provincial command. Keaveney 1979, 460, is a particularly clear indication of the heatedness of the debate. Cf. Luce 1970, passim; Katz 1977, 47-63, contra Mitchell 1975, 198. App. Mith. 22, B Civ. 55, and Vell. Pat. 2.18.3 all state that the command was assigned by
} 
know that the command was highly sought after, and we can assume that the elections for 88 were thus extremely competitive, since the Senate was to award the command to one of the

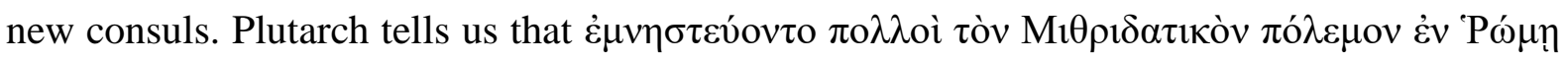
$\delta i \alpha ̀$ $\tau \tilde{\omega} \nu \delta \eta \mu \alpha \gamma \omega \gamma \tilde{\omega} \nu$ ('many were competing for the Mithridatic command in Rome with the help of demagogues'). ${ }^{16}$ Though it seems unlikely that Marius was one of the candidates, it is almost certain that he was desirous of the command (we shall return to this shortly).

C. Iulius Caesar Strabo sought the consulship of $88 .{ }^{17}$ By this token, he presumably had designs on the Mithridatic command. ${ }^{18}$ This was irregular: he had just held the curule aedileship in 90 and had never held the praetorship. ${ }^{19} \mathrm{He}$ was repulsed, possibly owing to the robust resistance of the tribunes P. Sulpicius and P. Antistius, whose activities suffice to demonstrate how objectionable Caesar's exception was felt to be by some. ${ }^{20}$ Both Marius and Sulla too, for whatever reason, detested Caesar. ${ }^{21}$ Cicero certainly implies that he sought a dispensation from the Senate, though it is unclear whether he was granted it; we do not know what became of his bid for the consulship save that it precipitated a violent struggle and that he was not elected. ${ }^{22}$

lot, meaning that the command was given at random to one of the two new consuls: Q. Pompeius Rufus had a fifty per cent chance of receiving it. Katz 1977, 47 n. 13, and Badian 1970, 31 n. 18, are sceptical about the randomness of the command. There is, however, no decisive evidence to say that Sulla rigged the votes. Cf. Taylor 1966, 73-4, for general observations on the Roman lot.

16 Plut. Mar. 34.1.

17 Caesar's attempt may be confidently dated in late 89: Badian 1969, 482; Keaveney 1979, 451 n. 1; Broughton 1991, 26-7; Seager 1994, 166; contra Lintott 1971, 446-8; Mitchell 1975, 198-201. Cic. Brut. 226 states that Sulpicius and Antistius, the tribunes for 88, raised their objection to Caesar's candidature while they were in office. But the tribunes for 88 assumed office in late 89 while the consuls were still canvassing for the consulship. It seems likely that they raised objections to Caesar's candidature as soon as they assumed office in December. Cf. Diod. Sic. 37.2.12.

${ }^{18}$ Keaveney's statement that 'our good sources have much to say about [Caesar's] consular hopes but nothing about a Mithridatic command' $(1979,453)$ is perplexing. Since the command was awarded to one of the consuls by lot, one would expect that an attempt at the consulship would presuppose the candidate's awareness of the possibility of attaining the command. It is worth noting that, if Caesar had been allowed to stand, which is debatable, he would have run against Sulla, as both were patricians. Keaveney 2005, 47, appears to overlook this latter point.

${ }^{19}$ Asc. 25C: omissa praetura.

${ }^{20}$ Cicero clearly disapproved of Caesar's attempt, describing the rival causa as optima and vera (Har. 43; Brut. 226).

${ }^{21}$ Plut. Sull. 5.5; Diod. Sic. 37.2.12. I am grateful to Prof. W. Jeffrey Tatum for allowing me to read a draft of his forthcoming chapter on the year 88 (cited as Tatum, forthcoming), which has been of immense help in unpacking this controversial year.

${ }^{22}$ Cic. Phil. 11.11 mentions the dispensation (solvatur legibus), though this subjunctive clause forms part of an ironic metaphor directed against L. Calpurnius Bestia. Cf. Katz 1977, 61-2, with some cautionary notes. There are several possible readings of Cic. Brut. 226: (i) the dispensation was never granted, having been opposed by the tribunes (Keaveney 2005, 46-7); (ii) it was granted by the Senate then overturned by the tribunes' interference; (iii) the dispensation was granted, the tribunes tried and failed to have it overturned, and Caesar lost the election as a legitimate candidate (Mitchell 1975, 199-201; Broughton 1991, 25-6; Keaveney 1979, 459-60, who later appears to change his mind). On the whole, it does seem unlikely that the Senate would have had the consensus to grant Caesar an exemption, given that he seems to have been 'at odds with the senatorial establishment' in 89 (Luce 1970, 191 n. 129; cf. Katz 1977, 58-9). Mitchell 1975, 201, too, has to cede this point, and so (unconvincingly) tries to move Caesar's bid for the consulship to the following year. 
It is possible that Pompeius Strabo, the standing consul, also coveted the command. Strabo was a dangerous unknown quantity, and had the unquestioning loyalty of the largest standing army in Italy. ${ }^{23}$ We can only speculate about what would have happened had Strabo not met a premature end before the conclusion of the Civil War. ${ }^{24}$ Velleius' wording is ambiguous, writing simply that Strabo was frustratus spe continuandi consulatus ('disappointed in his hope of prolonging his consulship'). ${ }^{25}$ The verb continuare would logically denote Strabo's desire for the consulship of the following year. Still, doubts have been raised over this reading of Velleius, with some suggesting that the passage refers to his designs on the consulship for $86 .{ }^{26}$ Granius, after all, suggests that Strabo wished to prolong the civil war of 87 so that he might take advantage of the uncertainty and win the consulship for himself. ${ }^{27}$ It is not entirely beyond the realms of possibility that both stories are true: Strabo wanted the Mithridatic command, and, having been rebuffed in 89 , made a further attempt for a second consulship in $87 .{ }^{28}$ Strabo celebrated a triumph on 25 December 89, presided over elections around this time, and retreated to his province, despite theoretically losing his imperium after his triumph. ${ }^{29}$ With his army in Picenum, Strabo would remain a headache for Rome's Senate and consuls until 87.

Nevertheless, Sulla and Q. Pompeius Rufus were elected to the consulship of 88. It was only after the command of the war was given to Sulla that the magnitude and gravity of the

\footnotetext{
${ }^{23} \mathrm{Cf}$. Asc. 79C: he was homo dis ac nobilitati perinvisus ('a man detested by gods and nobiles alike').

${ }^{24}$ Had Strabo lived, a period dominated by him, not Cinna, is considered a real possibility by several modern scholars: see Bulst 1964, 312 (on the likely dominatio Strabonis); Gruen 1968, 242 (Pompeii dominatio); and Katz 1976b, 333.

${ }^{25}$ Vell. Pat. 2.21.2.

${ }^{26}$ Keaveney 1978, 240-1, argues for Strabo's petition in 87 for the consulship of 86, reading Velleius' account chronologically (since his ensuing discussion concerns the events of 87) and the verb continuare as an (attempted) extension of his imperium from proconsular imperium in 87 to consular imperium in 86. Although Velleius does not always use the verb to denote continuatio of the same office (see, e.g., 2.91.3), he is never elsewhere so careless as to use consulatus to denote the proconsulship. Cf. Badian 1969, 470-1, and Steel 2013, 89 n. 37 for further discussion.

${ }^{27}$ Gran. Lic. 19C: Pompeius ultra Octavium progredi passus non fui $\langle t\rangle$, set ut Crassum revocaret impulit, ne ante debellaretur, quam comitia conficerentur, ut eum magistratum ipse invaderet, qui timebatur ('Strabo did not allow Octavius to progress any further, but insisted that he should recall Crassus, lest the war be finished before the elections were carried out, so that he [Strabo] himself may take hold of this magistracy [presumably the consulship], which was feared.') Cf. Hillman 1996, 88 n. 30, for a brief gloss of this passage.

${ }^{28}$ So Katz 1979, 329 with n. 6. For the orthodox view, see Brennan 2000, 782 n. 240; Seager 2002, 195 n. 22.

${ }^{29}$ See Badian 1958a, 228, and Luce 1970, 190, on the sequence of events. Badian 1969, 482 n. 104, tentatively suggests an unattested interregnum. Imperium militiae was renounced immediately after the conclusion of a triumph for both magistrates and promagistrates (Drogula 2007, 442-5). Tatum, forthcoming, suggests that his triumph and subsequent reactivation of imperium may have been a kind of consolation prize for the great man, having been denied the opportunity to run for the consulship. However, I am inclined to agree with Steel's hypothesis (2013, 94 n. 57; contra Badian 1969, 470-1) that his position in Picenum was considered illegal, given that the Senate almost immediately took action against him: they promptly attempted to put him on trial (Asc. 79C) and, later, to unseat him with Pompeius Rufus. Cf. Val. Max. 9.7 mil. 2: Strabo held the command invita civitate ('against the will of the citizenry').
} 
conflict became clear. While the Social War simmered away within Italy, Mithridates took advantage of Sulla's delays in reaching the east in truly brutal fashion. At his orders, many city-states in the east under Roman rule slew the resident Italian populations regardless of age or sex. Tens of thousands of Roman citizens and native Italians were butchered on a single day in early- to mid- $88 .^{30}$ It is a curiosity that, for all the horror expressed by our sources, there is minimal detail on the effect that such a massacre - which by weight of numbers surpassed Cannae in severity - had on the Roman People. ${ }^{31}$ The political classes seem too busy squabbling over the Italian question and the command of the war. However, the effect of the massacre on the Roman psyche is made abundantly clear by Cicero, speaking just a generation later: the massacre of Roman citizens left a macula ... penitus iam insedit ac nimis inveteravit in populi Romani nomine ('blemish that, to this very day, is utterly fixed and rooted beyond measure in the reputation of the Roman People'). ${ }^{32}$ We need not doubt that this act of extraordinary violence greatly distressed a Roman public still reeling from the effects of the Social War. What is more, Mithridates had now successfully seized vast swathes of the wealthy Greek East, with most city-states voluntarily joining his side. The Mithridatic War would not be the straightforward guarantor of gloria that it had initially seemed..$^{33}$

Meanwhile, on the home front, the enfranchisement of the Italians remained a hot topic. The subversive but brilliant tribune of 88 , P. Sulpicius, initially a stalwart of the senatorial élite, promoted a raft of popular legislation. The motivations behind Sulpicius' apparent change of political direction have been debated at great length. ${ }^{34}$ He gained traction by his opposition to Caesar Strabo's premature bid for the consulship for 88 . He was, Cicero says, representing the vera causa at this stage in his career. ${ }^{35}$ But one of his subsequent acts as tribune exacerbated the violence in Rome that marred the year of Sulla's first consulship. Among other bills introduced as tribune, Sulpicius attempted to enrol the Italians, who were still politically

\footnotetext{
${ }^{30}$ App. Mith. $22-3$ provides the narrative with gruesome details. Plut. Sull. 24.4 supplies the figure of 150,000, though Memnon's figure of 80,000 is generally considered closer to the truth (22.9). Cf. Liv. Per. 78, Vell. Pat. 2.17.1-3. For discussion on the death toll, see Mayor 2010, 383 n. 2. Appian provides the best guide to the chronology of the time, but the divergence in focus between $B \mathrm{Civ}$. and Mith. makes it difficult to cross-reference the dates. We know that Rome declared war on Mithridates in late 89 before the consular elections at Rome, and, at some point early in Sulla's consulship, Mithridates raised a large army. Thirty days thereafter, the massacre took place (Mith. 22). Cf. McGing 1986, 113 n. 118.

${ }^{31}$ Liv. Per. 78 mentions only the trepidatio in the eastern city-states as they were forced to pick sides, caught between two major powers.

${ }^{32}$ Cic. Man. 7.

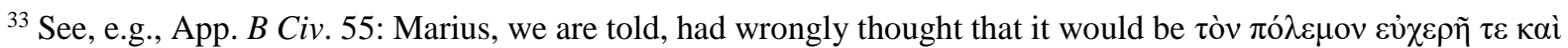
$\pi \circ \lambda u ́ \chi \rho v \sigma o v$ ('a both straightforward and lucrative war').

${ }^{34}$ Gruen 1965, 72; Badian 1969, 481-90; Mitchell 1975. However, Powell 1990, 449-50, holds that Sulpicius never underwent the volte-face that these scholars suggest.

${ }^{35}$ Cic. Brut. 226. Cf. Har. 43 (optima causa).
} 
marginalized following the Social War, into the existing thirty-five voting tribes. ${ }^{36}$ Sulpicius sought the support of the consular Marius, who had not played a prominent role in the Social War, to give his proposal some heft. Notwithstanding his lack of involvement in domestic affairs over the previous decade, Marius still held a great deal of clout. ${ }^{37}$ The two men needed each other.

Sulpicius gained his support by including in his programme a proposal to divest Sulla of the Asian command in order to give it to Marius as a proconsul. ${ }^{38}$ Marius had coveted the command before its allocation - and still desired it. He put on a bizarre public display of physical prowess in the Campus Martius, though many of those watching saw the spectacle as pitiable and ridiculous. ${ }^{39}$ Sulpicius' attempts to enfranchise the Italians precipitated renewed violence. ${ }^{40}$ The chaos continued throughout the days leading up to the vote on Sulpicius' proposals. Asconius exaggerates when he asserts that this initium bellorum civilium fuit ('was the beginning of the Civil War'). ${ }^{41}$ But significant violence did erupt within Rome as a result, much of it encouraged by Sulpicius and Marius. ${ }^{42}$

Sulla, who was absent from the city at the time finishing off affairs in the Social War, returned in order to restore order, suspending public business. If Sulpicius had been on good terms with Sulla previously, relations had certainly deteriorated by now. But Sulpicius responded with escalated violence; Sulla, perhaps unaware of the plan to divest him of his Asian command, fled the city. ${ }^{43}$ With the moratorium lifted after Sulla's flight, Sulpicius, in addition to his radical legislation, at the behest of Marius, publicly proposed the law to strip the Mithridatic command from Sulla and award it to Marius. These measures were almost certainly carried by way of violence and intimidation. ${ }^{44}$ The ensuing course of events is well

\footnotetext{
${ }^{36}$ App. B Civ 1.55; Liv. Per. 77.

${ }^{37}$ See Keaveney 1983b, 54, on Marius' continued influence. Cf. Badian 1958a, 208-15, on Marius' activities during the 90 s.

${ }^{38}$ Plut. Mar. 34.1; Sull. 7.1.

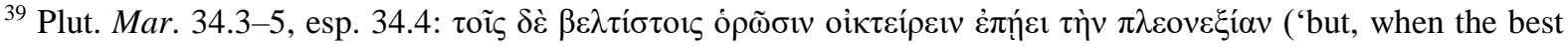
men witnessed the spectacle, they began to pity his arrogance and vanity'). Such attitudes are likely the reason why he never stood for the consulship. Tatum, forthcoming, suggests that these theatrics may have been displaced in Plutarch's narrative, and thus occurred before the elections for 88. Still, it remains clear that he was never a candidate, and he continued to covet the command after it was assigned to Sulla.

${ }^{40}$ Appian's explanation (B Civ. 1.55), that the enfranchisement of the allies was the primary reason, should be believed over Plutarch's (Mar. 35, Sull. 8), who posits the abrogation of Sulla's Mithridatic command. Cf. Powell 1990, 450-2.

${ }^{41}$ Asc. $64 \mathrm{C}$

${ }^{42}$ Keaveney 1983b, 57, suggests that Sulpicius and Marius had a private army at their employ (cf. Plut. Mar. 35.2). Mitchell 1975, 203-4, too, places the blame for the disturbance on Sulpicius.

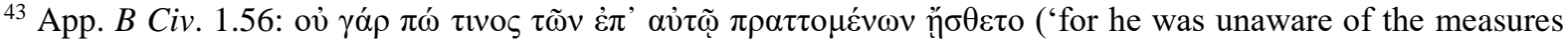
carried out against him'). Luce 1970, 192-3 n. 132, however, reasons that 'Sulla must have had some suspicions about Sulpicius' intentions with reference to the command'.

${ }^{44}$ Keaveney 2005, 50.
} 
documented: Marius sent his legate to Sulla ordering him to give up his command; Sulla's troops murdered him. ${ }^{45}$ Sulla, dismayed by this unacceptable slight to his dignitas, returned to Rome with his battle-hardened army, fresh from victories in the Social War and ready for further exploits in the east. ${ }^{46}$ This act of civil aggression was unprecedented; with the dubious exception of Coriolanus, never before had a Roman marched on the city. Naturally, Sulla, with his massed ranks, seized the city, although almost no one of note from the aristocracy joined his forces. ${ }^{47}$

Though the march on Rome naturally presupposed violence, our sources do not paint a picture of mass bloodshed. Nevertheless, so abhorrent it was that the urban plebs forcefully resisted the fully armed legionaries. Appian makes it clear that the city was stoutly defended not just by the partisans of Sulpicius and Marius, but by the inhabitants of the houses near the

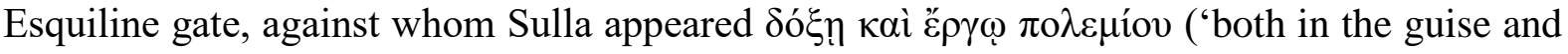
action of an enemy'). ${ }^{48}$ Sulla retaliated with threats to set fire to their houses. ${ }^{49}$ Many innocent people were killed. ${ }^{50}$ Sulla's march set a disturbing precedent. In a grisly presage to the forthcoming massacres by Marius and Cinna, and the later Sullan proscriptions, Sulpicius' head may have been placed on the rostra for all to see. ${ }^{51}$ Eleven others were declared public enemies, though their eventual fate, with the exception of Marius and his son, is unknown.

At last, we come to Cinna. It is impossible to tell for certain whether Cinna had any lasting political relationship with Marius and Sulpicius prior to his election to the consulship of 87 .

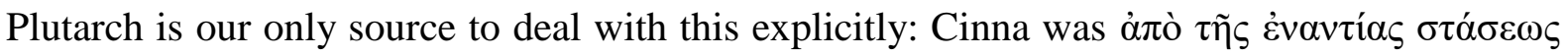
('from the opposing faction'). ${ }^{52}$ Most modern scholars have doubted this version of events: he developed his pro-Italian scheme after his election and had no lasting political bond with

\footnotetext{
${ }^{45}$ Val. Max. 9.7 mil. Rom. 1.

46 App. B Civ. 1.57-8. Much ink has been spilled on this episode. See, among others, Levick 1982, 503-8; Keaveney 2005, 50-6; Salmon 1967, 371-2; Steel 2013, 93-4; Tatum, forthcoming.

${ }^{47}$ App. B Civ. 1.57.

${ }^{48}$ App. B Civ. 1.58 .

${ }^{49}$ App. B Civ. 1.58.

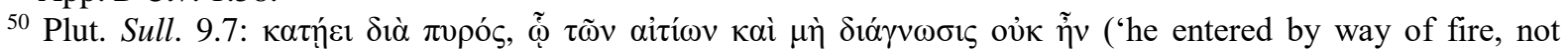
distinguishing between those responsible or not').

${ }^{51}$ Vell. Pat. 2.19.1. Neither Liv. Per. 77, Plut. Sull. 10.1, nor App. B Civ. 1.60 mention this; it is possible that Velleius' addition of this aspect to the narrative may have been an invention to provide narrative concordance with the later events.

52 Plut. Sull. 10.3.
} 
Marius or Sulpicius prior to his expulsion from the city. ${ }^{53}$ Their scepticism appears to be valid. It strikes me as very unlikely that Cinna could have got himself elected as a prominent supporter of the Sulpician scheme. After all, Cinna would have needed significant élite support among the old citizens to get elected in the first place. ${ }^{54}$ Although Sulla had been reprehensible in his actions, he still stood for traditional Roman upper-class values; a rejection of the man did not mean a rejection of his principles. Any prominent advocate of Sulpicius' ideas was, at the very least, unlikely to reach the consulship.

Out of necessity, Cinna's position was ambiguous. Besides, consular candidates seldom campaigned on political issues. ${ }^{55}$ As Q. Cicero advises: nec tamen in petendo res publica capessenda est neque in senatu neque in contione ('when canvassing, political affairs are not to be resorted to either within the Senate or in a contio'). ${ }^{56}$ His encounter with Marius is later represented by all of our sources as a spontaneous and mutually beneficial relationship: just as two previously unrelated politicians (Marius and Sulpicius) had briefly found mutual support in 88, so too would Cinna and Marius. This is not to say that Cinna demonstrated a complete volte-face. It is scarcely likely that he suddenly decided to support the Italians in late 88 or early $87 .{ }^{57}$ But a sympathy for the Italian cause does not necessarily equate to a political relationship with Marius and Sulpicius. ${ }^{58}$ At the very least, it seems that Cinna was no prominent advocate of the Italian cause before his election to the consulship.

Much of this, naturally, must have a bearing on our interpretation of the political ascendance of Cinna. There had been calamitous civil violence within the city as Sulpicius attempted to force his bills through; the allies, temporarily appeased, were still largely disenfranchised; thousands upon thousands of Romans had been butchered in the east, and Mithridates, though not an existential threat to the city of Rome, had swiftly taken control of some of Rome's most profitable territories; and, most pressingly, a standing consul had just

\footnotetext{
${ }^{53}$ See, e.g., Mommsen 1901, 315; Bennett 1923, 6-7; Gruen 1968, 229; Katz 1976b, 535.

${ }^{54}$ Cf. Lovano 2002, 28; Keaveney 1987, 175.

55 Yakobson 1999, 149-83, attempts to revise this notion, claiming that electoral canvassing was more overtly political than usually held. It is of interest that Yakobson states only that the elections for 87 were 'heavily influenced by politics' (p. 161), which is doubtless true. But, he (I think rightly) never suggests that Cinna campaigned on such political issues, save that he was not a supporter of (nor supported by) Sulla. Cf. Tatum 2003/04, 206, for a cogent critique of some of Yakobson's handling of evidence.

${ }^{56}$ Q. Cic. Comm. Pet. 53. Yakobson 1999, 152-5, alleges that the importance of this passage has been exaggerated, though the traditional view remains defensible. Morstein-Marx's gloss of this passage $(1998,264)$ is characteristic of this perspective: '[the candidate] must avoid political speechmaking during canvassing to avoid the risk of upsetting the delicate balance of support among senators, equites and multitudo that was advisable, and in most cases surely demanded, for electoral success.'

${ }^{57}$ Lovano 2002, 28-9, provides some good evidence to this effect.

${ }^{58}$ Katz 1979, 162 n. 2, provides insight into the factionalism of the time 'many, if not most senators were neither Sullani (or Octaviani) nor Mariani (or Cinnani), but simply concerned to protect their own interests'. Cf. Katz 1976b, 521-3.
} 
crossed the pomerium with his army, killed a standing tribune, and declared a consular and several other nobles public enemies. By the end of 88, Rome was in crisis. And yet, extraordinarily, constitutional procedure continued to be diligently followed. The consular elections for 87 were demonstrably highly competitive. Despite Asconius' bleak assessment, the Civil War had not yet broken out to devastating effect.

Sulla made clear attempts to provide a legal basis for his actions. Declaring his personal enemies hostes gave Sulla a means to justify his actions without recourse to senatorial approval (which he would never get). ${ }^{59}$ Before departing for the east, Sulla, still the legitimate consul for the last few months of 88 , passed a raft of legislation to repeal the bills put forward by Sulpicius. ${ }^{60}$ The enfranchisement of the Italians was halted. Sulla's laws were favourable to the Senate: he nullified the power of the tribunes, stipulating that all laws should pass through the Senate before being put to the People. These laws could (possibly) now only be passed by the timocratic comitia centuriata, essentially resulting in the drastic curtailment of power in the two popular assemblies. ${ }^{61}$ Furthermore, the practical capacities of the tribunate were curtailed, presumably to the same extent as his piece of legislation of 81 in which the tribunes had their right of veto limited, were prevented from initiating legislation, and forbidden from holding magistracies subsequently. ${ }^{62}$

Although Sulla set a disturbing precedent by marching on Rome, his actions did not immediately precipitate a breakdown in republican politics. ${ }^{63}$ As Plutarch tells us, both the Senate and the People were appalled by Sulla's actions, ${ }^{64}$ to the extent that they refused to elect those candidates whom the presiding magistrate had endorsed:

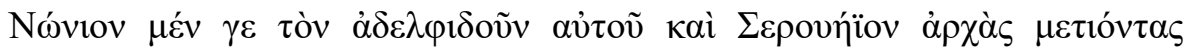

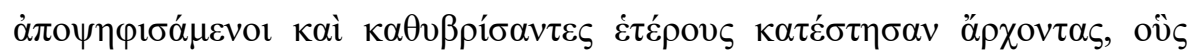

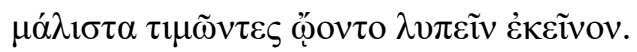

\footnotetext{
${ }^{59}$ So Bauman 1973, 282-3. Cf. Val. Max. 3.8.5, where Sulla is said to have intimidated the Senate into declaring Marius hostis.

${ }^{60}$ App. B Civ. 1.59 is our only detailed source for these laws. Cf. Cic. Phil. 8.7.

${ }^{61}$ Seager 1994, 172, conversely, has suggested that the comitia tributa was unaffected by Sulla's reforms, while the other details preserved by Appian are accurate.

${ }^{62}$ All App. B Civ. 1.59 tells us is that the tribunes' power was removed ( $\pi \varepsilon \rho \varepsilon \lambda \lambda^{\circ} v \tau \varepsilon \varsigma$ ), though the actions of the tribunes in the following year exhibits that they still held the right of veto in some contexts (1.64). The similarities between his legislative agendas of 88 and 81 are striking, and should make us cautious about the particulars of Sulla's reforms of 88 (see list of laws of 81 in MRR 2.74-6). Cf. Keaveney 2005, 56-7.

${ }^{63}$ Indeed, Sulla's army had left the city by the time of the consular elections. They did not intimidate the Roman populace into voting for a pro-Sullan candidate. On the withdrawal of Sulla's troops, see App. B Civ. 1.64; Badian 1958a, 235 n. 4; Katz 1976b, 499; Keaveney 2005, 57-8.

${ }^{64}$ Plut. Sull. 10.2. Cf. Gruen 1968, 229: '[the hostility of the senate] is conjecture, but reasonable conjecture.'
} 
('They refused to vote for Nonius, his nephew, and Servius, who were the candidates for offices, treating them with great disrespect, appointing other candidates instead; they believed that preferring them would vex Sulla greatly.' $)^{65}$

This Servius has been identified as P. Servilius Vatia (cos. 79), a patrician candidate of some prestige who had celebrated a triumph that very year, probably thanks to his friend Sulla. ${ }^{66}$ That a man who had recently paraded through the streets of Rome with the spoils of war to the clamour of hundreds had somehow failed to get elected to the summa laus is indicative of Sulla's unpopularity. ${ }^{67}$ Plutarch links his repulsa directly to his endorsement by the detested Sulla. And, crucially, it was upper-class disapproval that lost him the election. ${ }^{68}$ The consular elections of 88 represented something of a rejection of Sulla and many of his preferred candidates. Cn. Octavius, Cinna's consular colleague of the year, was seemingly not a preferred candidate of Sulla. ${ }^{69}$ That Sulla met with both popular and senatorial disapproval and rejection after his march on Rome is beyond dispute. ${ }^{70}$ The elections of Cinna and Octavius to the consulship of 87 need not be seen as a surprise, even though Octavius seems to have been unheralded and, worst of all, unintelligent. ${ }^{71}$ Cinna had served with some success in the Social War, and was both a noble and a patrician.

Plutarch and Dio now inform us that Sulla, feigning to be pleased with the appointment (what else could he do under the circumstances?), made Cinna swear an oath to preserve Sulla's legislation. ${ }^{72}$ The legitimacy of this story has been called into question, not least because Appian does not mention such a pact between Sulla and Cinna, and Octavius was never reported to have taken the oath. ${ }^{73}$ Its historicity need not concern us. Two things are clear: the oath had no binding effect on Cinna, who soon proceeded with contrary laws; and the story of

\footnotetext{
65 Plut. Sull. 10.3.

${ }^{66}$ Broughton 1991, 17 (but see Farney 2004, 248-9, for an alternative reading). The identification of the other candidate to have been repulsed, Nonius, is unclear, as is the magistracy for which he was running. He does not, at least, seem to have been a candidate for the consulship; see Katz 1976b, 540-1.

${ }^{67}$ Katz 1976b, 522.

${ }^{68}$ So Badian 1976, 69 n. 44: 'what is shown by the centuriate assembly is the hostility of the propertied classes.' Cf. Katz 1976b, 538 with n. 158.

${ }^{69}$ Katz 1976b, 532-3, is surely correct that Octavius was not 'a partisan of Sulla'. Plutarch's narrative (Sull. 10.3), like many later writers (see, e.g., App. B Civ. 1.1), projects a simplistic binary model onto the conflicts of the time. But see the critical positions of Pelling 2002, 212-17; Katz 1976b, 535 with n. 149, and Shatzman 1975, 204-5.

${ }^{70}$ Contra Bennett 1923, 5-6, who believed that Cinna was a handpicked candidate of Sulla who subsequently betrayed him. Katz 1976b, 536-8, provides a cogent alternative.

${ }^{71}$ Cic. Brut. 176; Katz 1976b, 530-1.

${ }^{72}$ Plut. Sull. 10.3-4, Cass. Dio fr. 102.3-4.

${ }^{73}$ Lanzani 1907, 3; Gruen 1968, 229 n. 69. Cf. other sources listed in Katz 1976b, 545 n. 182, though Keaveney 2005, 61, sees no reason to doubt the story. On Octavius, see Steel 2013, 95 n. 59.
} 
the oath played usefully into Sulla's later propaganda, painting Cinna as ingratus of Sulla's beneficium - a traitor and oath-breaker. ${ }^{74}$

Strabo remained a problem late in 88 , for Sulla personally, for the Roman aristocracy, and for the republic as a whole. With the final events of the Social War still playing out, Strabo still held proconsular imperium and had his army encamped near Rome. The command of this army was transferred to the other outgoing consul, Q. Pompeius Rufus. Sulla saw an ally in Rufus, and it would have been expedient to leave him in a position of power while campaigning in the east. ${ }^{75}$ In theory, this procedure was not out of the ordinary: proconsular commands were conferred ex senatus consulto; but removing proconsular command thus was unusual, and surely stemmed from the animosity between Strabo and the Senate, and perhaps the illegality of Strabo's position. ${ }^{76}$ The outcome is well documented: Pompeius Rufus met a violent end at the hands of Strabo's troops. ${ }^{77}$ While republican electoral norms remained intact in the concluding months of 88 , the threat of standing armies and future conflict within the city of Rome was very real indeed. The consuls had clout within Rome, but they seemingly could command less influence than normal in Italy owing to the sworn oaths to active generals. These personal 'client armies' would remain a problem for decades. ${ }^{78}$ Strabo was not a candidate for the consulship of 87 along with Cinna and Octavius; it would therefore appear that Strabo spent the end of 88 and the start of 87 , while events within Rome once again regressed into violence, loitering in Picenum with his substantial army. His (and its) potency and menace had been made abundantly clear by the death of Sulla's colleague.

But what did Cinna really do during his first consulship? The basic events of early 87 are clear to us. Despite the alleged oath, Cinna proceeded against Sulla forthwith, perhaps before the now proconsul had departed for the east. ${ }^{79} \mathrm{We}$ can only speculate as to the content of these accusations, though there were demonstrably 'a number of points on which Sulla was

\footnotetext{
${ }^{74}$ The accounts heavily tainted by Sullan propaganda (Plutarch and Dio) assert that Sulla granted Cinna the right to be consul (as if he could refuse under these circumstances without seeming tyrannical; see Staveley 1972, 20911; cf. Lovano 2002, 31), and thus Cinna owed Sulla a debt of gratia. Betrayal of this personal quid pro quo agreement was particularly reprehensible, as Cicero repeatedly shows (see, e.g., Att. 9.2a.2; Phil. 2.6).

${ }^{75}$ Keaveney 2005, 61-2.

${ }^{76}$ Badian 1958a, 235. Furthermore, App. B Civ. 1.63 tells us that it was the Roman People that gave Pompeius Rufus command of Italy. The doubtful mechanics of this transferral of power need not concern us here, though the actions of Sulla and the Senate are suggestive of the illegality of Strabo's actions (see p. 16 n. 29 above). Badian 1955, 111-12, tentatively argues that Sulla also attempted to pass a lex divesting Strabo of power.

${ }^{77}$ App. B Civ. 1.63; Liv. Per. 77; Val. Max. 9.7 mil. Rom. 2.

${ }^{78}$ See, e.g., Badian 1958a, 236 et passim.

${ }^{79}$ Plut. Sull. 10.4 is explicit that the tribune Verginius (read M. Vergilius; MRR 2.47) attempted to prosecute Sulla before his departure; Cic. Brut. 179, however, seems to indicate that such proceedings occurred after Sulla's departure (L. Sullae imperatori diem). Cf. Cic. Dom. 83.
} 
open to attack.' 80 This accusation seems neither to have been designed to force Sulla to return nor to make him flee Italy. ${ }^{81}$ It was a propaganda ploy, intended to cast Sulla as a flouter of Roman law. Sulla left with his army and a ruined reputation to boot, and the accusation would exacerbate this. More importantly, however, Cinna instigated a raft of legislation strongly reminiscent of the recently repealed Sulpician proposals. ${ }^{82}$ Once again, the enfranchisement of the Italians was central to the legislative programme: the allies were to be distributed among the existing thirty-five tribes and thus be given equal voting rights. It is said that some among the allies bribed Cinna to promote this bill. ${ }^{83}$ Although Cinna's proposals to recall the exiles of Sulla's hostis declarations would follow soon after, Cicero makes it clear that the novorum civium suffragium was the central issue in these proposals. ${ }^{84}$

One would assume that such a proposal would - as it had done for Gracchus, Drusus, and Sulpicius before him - prove deeply unpopular across all classes. The Roman public had made its views on Italian enfranchisement abundantly clear, and the perturbing events of the Social War would not have done anything to curb this resentment towards the allies. It is difficult to understand just how Cinna could have thought that these proposals would pass through peaceably. As can be expected, violence once again erupted in the streets of Rome. As in the stories of Sulpicius' attempts at enfranchisement, many of our sources place the blame for the violence on the instigator of the reforms, though advocates of both sides carried concealed daggers. ${ }^{85}$ Some of the tribunes favourable to Octavius vetoed Cinna's proposal; but

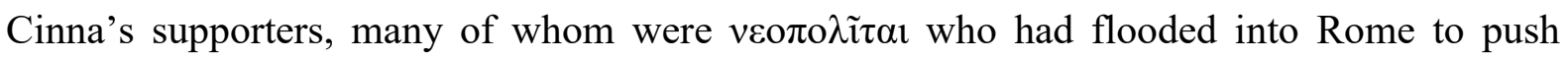
through the bill, started a riot. ${ }^{86}$ This riot become a battle, resulting in a vast number of deaths. Cicero vividly describes a bloodbath in which omnis hic locus acervis corporum et civium

\footnotetext{
${ }^{80}$ Bulst 1964, 307. It was quite possibly for the murder of Sulpicius; see Bennett 1923, 7.

${ }^{81}$ Keaveney's argument that Cinna considered depriving Sulla of his command, just as Sulpicius had done, is intriguing (1983b, 85-6; 2005, 62-3; contra Bulst 1964, 307), though there is no persuasive evidence to this effect. Besides, such an attempt would have been risky and pointless. Cass. Dio fr. 102.1 suggests that the court proceedings were constructed to force Sulla out of Italy, but, as Gruen 1968, 230, observes, 'Sulla was going anyway'.

${ }^{82}$ See multitudinous sources in MRR 2.46.

${ }^{83}$ App. B Civ. 1.64. This story has been doubted. See, e.g., Katz 1976b, 535 n. 149; Lovano 2002, 37. Nevertheless, it would explain why the previously unaligned Cinna suddenly decided to take up the Italian cause, having fought against them just two years earlier.

${ }^{84}$ Cic. Phil. 8.7. Contra Flor. 2.9.9 who mentions only the hostes. Lanzani 1907, 18-20, expresses doubt that Cinna would have attempted to recall the exiles at this early stage; though the argument of Bulst 1964, 308-9, that both items were on Cinna's agenda at some point, even though the more important was the allocation of the socii, deserves consideration. After all, App. B Civ. 1.64 lists both issues. Cf. Lovano 2002, 32-3 with n. 25.

85 App. B Civ. 1.64. Appian's sympathies are clear, describing Octavius' supporters as $\kappa \alpha \theta \alpha \rho \omega ́ \tau \varepsilon \rho o v$ ('more innocent'). Cicero places the blame on Octavius (Cat. 3.24). Bulst 1964, 311, may well be right that the scale of violence from Octavius took Cinna by surprise, but this does not necessarily absolve Cinna of responsibility.

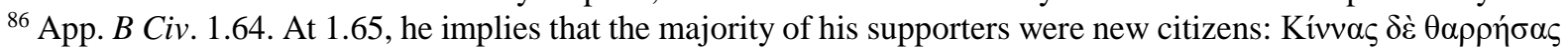

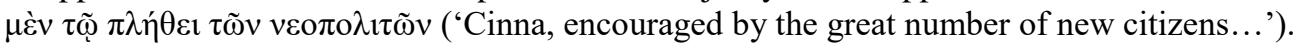


sanguine redundavit ('this whole place overflowed with heaps of bodies and the blood of our citizens'). ${ }^{87}$ Plutarch, surely with exaggeration, says that 10,000 from Cinna's side alone were killed. ${ }^{88}$ Regardless of the precise figures, this was a tribulation that left a profound impact on the Roman psyche. This was a day on which the two consuls had gone to war within Rome. Cinna was forced to leave the city. ${ }^{89}$

At first blush, Cinna's actions early in his consulship of 87 appear to betray a great deal of naïveté: it was surely depressingly predictable that a reviving of the Italian question would result in civil unrest. Our later sources are hostile to his legislative programme (Livy's epitomator calls them perniciosae leges), but it is entirely plausible that the Roman People too would have been largely unfavourable. ${ }^{90}$ Perhaps Appian is right that he was bought by the Italians (a trope to be treated with caution). Perhaps Cinna genuinely sympathized with the Italian plight. Perhaps he saw a chance to capitalize politically on the divisive issue. ${ }^{91}$ Or perhaps he perceived the real and imminent need for the restive Italians to be granted their deserts, lest another Social War break out. ${ }^{92}$

These personal and political explanations are not mutually exclusive. It bears remembering that, by now, (most of) the Italians were Roman citizens, albeit unenrolled; and, as Appian makes clear, they well outnumbered the old citizens, hence the reluctance to give them equal voting rights. ${ }^{93}$ It is entirely possible that Cinna gambled in favour of the Italian cause, judging that their sheer weight of numbers could tip the balance in his favour, securing immense gratia (if not immediate support at the ballot box, which he would be of lesser value since he had already been elected to the consulship) from a massive group of new citizens. After all, Sulpicius had only been scuppered by Sulla's invading army; both movements had to have generated a good degree of support to be able to gain traction in the first place. ${ }^{94}$ Sulpicius'

\footnotetext{
${ }^{87}$ Cic. Cat. 3.24. Though Cicero presents this episode as part of the cycle of violence in the 80s, his image of the Bellum Octavianum is the most striking. Cf. Morstein-Marx 2004, 112 n. 199, on the structure of this passage. Cic. Sest. 77 provides further lurid details of the bloodshed.

${ }^{88}$ Plut. Sert. 4.5 .

${ }^{89}$ Lovano 2002, 34, is sceptical about Appian's story (B Civ. 1.65) that Cinna tried (and failed) to enlist slaves. This is a common enough slight against the causes of Marius and Cinna (cf. Plut. Mar. 35.5; Sull. 9.7), and it is difficult to separate fact from fiction in these instances. Sartori 1973, 151-64, however, suggests that this tactic was a sign of the instability of the time, and many of these stories have basis in fact.

${ }^{90}$ Liv. Per. 77.

${ }^{91}$ So Katz 1976a, 328.

92 Tatum (forthcoming) presents some of these possibilities with regard to Sulpicius' reforms. They adequately translate to the situation in early 87.

${ }^{93}$ App. B Civ. 1.49. Sulpicius and Marius had, too, perceived the political expediency in enrolling the allies a year earlier (App. B Civ. 1.55). Brunt 1971a, 89, has expressed doubts about whether the Romans were actually outnumbered by new citizens. Cf. Powell 1990, 451, for doubts over the practical effectiveness of such an enrolment, at least in terms of voting numbers.

${ }^{94}$ See Tatum (forthcoming) on Sulpicius' numbers. If Plutarch's death figures (Sert. 4.5) are even remotely correct, then Cinna must have had some supporters among the urban plebs. Cf. Brunt 1971a, 89-90. Perhaps
} 
final defeat may be more directly related to his attempts to give Sulla's eastern command to Marius; although his attempts to enfranchise the Italians had resulted in violence and anger, this was not the cause of his failure. It is inconceivable that Cinna would have acted as he did had he not believed he could get even a small amount of support from the urban plebs and Roman aristocracy. In the end, it would seem that he was outmanoeuvred by Octavius, his bold attempts rebuffed by organized and violent resistance. ${ }^{95}$ Cinna's endeavours could have worked.

But they did not. Cinna was removed from the consulship and exiled. Octavius' motives are reasonably obvious. Cicero intimates that Octavius desired supreme power, but this is hyperbolic. ${ }^{96}$ Octavius was seen to be protecting the oligarchic status quo, a noble tradition in aristocratic circles. ${ }^{97} \mathrm{He}$ had resorted to extreme violence to achieve this end. Religious reasons were contrived to justify the flagrantly illegal expulsion of a consul: the Sibylline Books, conveniently enough, indicated that there would be tranquillum otium et securitatem futuram ('tranquil peace and future security') if Cinna and the six tribunes who assisted him were expelled. ${ }^{98}$ Senatorial compliance with Octavius' actions is transparent. Following Cinna's expulsion, a suffect consul was chosen in his place: L. Cornelius Merula, the flamen Dialis. ${ }^{99}$

Now we encounter the first instance of a questionable election, a few months before the socalled domination of Cinna. The election of a consul suffectus should theoretically follow the same procedure as that for a consul ordinarius. ${ }^{100}$ But very few suffect consuls had been chosen in recent times; even during the perturbation of the Cimbric and Social Wars in which

crucially, Cinna did not presently enjoy the vocal support of a figure like Marius who held such sway with the equestrian order (cf. Vell. Pat. 2.20.5).

${ }^{95}$ Bulst 1964, 311.

${ }^{96}$ Cic. Har. 54: utrique horum [i.e. Cinnae Octaviique] fortuna regnum est largita ('fortune furnished each of them with regal power'). Bulst 1964, 312, is too confident in his assertion that 'Octavius certainly wanted unchallenged supreme command for himself’ based on this one Ciceronian passage. On this, see Katz 1979, 164. ${ }^{97}$ Katz 1976a, 328.

98 Gran. Lic. 15C. One suspects that having so many of the people's representatives on side would have represented something of a propaganda coup for Cinna, as for Caesar a generation later (see, e.g., Caes. B Civ. $1.5)$.

${ }^{99}$ Contrary to common practice, Merula seems to have held the consulship and the priesthood simultaneously. However, the restrictions mentioned by Gellius (NA 10.15) seem to have fallen out of practice by the late republic (OCD 580), or at the very least could be circumvented by a special exemption or religious loophole (Liv. 30.50.79). Cf. Lintott 1999, 183; Beard 1990, 24-5; Gabba 1967, 184.

100 Phillips 1997, 104-5, provides a useful outline of the procedure of electing suffect consuls. Note that, unlike regular elections, the suffect consul assumed office immediately following the renuntiatio (cf. Linderski 1986, 2169). Other cases, individual irregularities notwithstanding, serve to illustrate the importance of full comitial elections for the choice of suffect consuls (Liv. 23.31.13-14; 41.16.5-16; Cic. Fam. 7.30.1). Cf. Golden $2013,69$. 
numerous consuls had died in office, no suffect had been elected. ${ }^{101}$ The reasons for this may, of course, be purely practical: elections were an expensive and time-consuming endeavour, and if the consul perished late in the year, it was likely judged to be appropriate for a sole consul to see out the rest of the year. Additionally, the crisis might be so severe that the presiding magistrate may not have the time to return to the city to conduct elections. ${ }^{102}$ While uncommon, the institution of suffect consul remained conventional throughout the late republic. And yet, it had demonstrably fallen out of favour. The appointment of Merula to the consulship was thus a symbolic as well as a practical gesture. The message was obvious: Cinna had been justly removed; there was no position for him to fill. It was as if Cinna were already dead.

Some have recently expressed their suspicion regarding the mechanics of the election of Merula. ${ }^{103}$ Our only sources of information state that it was the Senate that had the initiative.

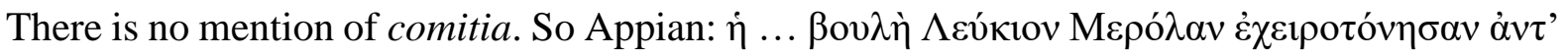

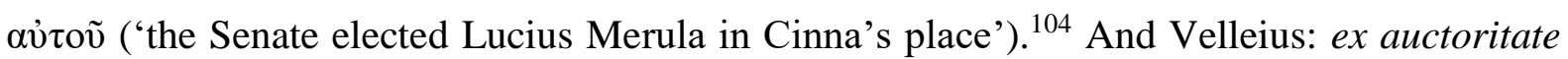
senatus consulatus ei abrogatus est suffectusque in eius locum L. Cornelius Merula flamen dialis ('by authority of the Senate, [Cinna's] consulship was abrogated and in his place Cornelius Merula, the flamen dialis [became] the suffect'). ${ }^{105}$ Plutarch, meanwhile, identifies

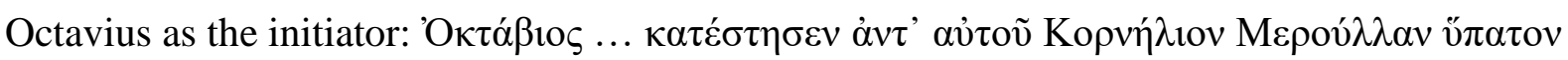
('Octavius made Cornelius Merula consul in [Cinna's] place'). ${ }^{106}$ Merula was apparently reluctant to hold the position, which might suggest the forceful initiative of Octavius and the Senate. ${ }^{107}$ If we take these accounts literally, Merula became consul through an unconventional procedure, perhaps behind closed doors without confirmation from the People.

But the lexical decisions of our sources often prove little about the running of comitia. Appian uses an identical construction in his Civil War to refer to the election of M. Calpurnius

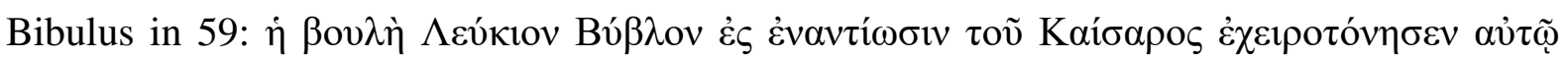

\footnotetext{
${ }^{101}$ No suffect consul had been elected since 130 (MRR 1.501-2). Since then, the deaths of consuls had not triggered an election for a suffect: M. Porcius Cato (cos. $118 \dagger)$; P. Cornelius Scipio Nasica Serapio (cos. $111 \dagger)$; L. Cassius Longinus (cos. $107 \dagger)$; L. Aurelius Orestes (cos. $103 \dagger)$; consuls had died in office for three consecutive years before 87 without recourse to elections for suffect consuls: P. Rutilius Lupus (cos. $90 \dagger)$; L. Porcius Cato (cos. $89 \dagger)$; Q. Pompeius Rufus (cos. $88 \dagger)$. Promagistrates could be nominated instead to fulfil the martial exigencies of the consul, thus circumventing the need for an election (e.g. C. Marius in 90), though there would remain a sole consul for the remainder of the year.

102 App. B Civ. 1.44 states that suffect elections would have been held in 90 after the death of Rutilius had his consular colleague been able to return to the city to preside over them.

${ }^{103}$ Lovano 2002, 35; Morstein-Marx 2011, 265-6 with nn. 30, 33. Cf. Taylor 1941, 114. The orthodox position remains that of Katz 1979, 162-6; Steel 2013, 95.

104 App. B Civ. 1.65. The singular predicate here may be construed in the plural to match the plural verb, a construction not uncommon in Appian (cf. B Civ. 1.26; 3.86; 3.88). Cf. Smyth 1956, 228-9; Katz 1979, 163 n. 3. 105 Vell. Pat. 2.20.4. The similarity in wording between Appian and Velleius suggests a common source.

106 Plut. Mar. 41.1.

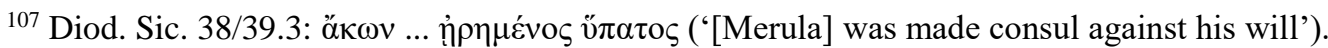




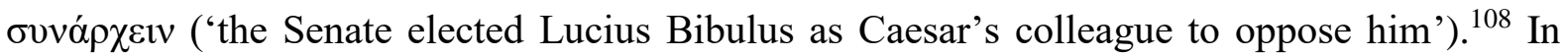
reality, the Senate did no such thing. ${ }^{109}$ Accordingly, the verb $\chi \varepsilon 1 \rho o \tau o v \varepsilon ́ \omega$ with the subject $\dot{\eta}$

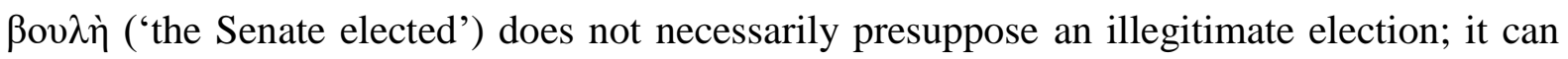
simply mean that the Senate's preferred candidate was chosen. Such careless wording in describing comitial proceedings is not uncommon in Appian. ${ }^{110}$ Furthermore, our sources are often unconcerned about comitial proceedings, ignoring the method of election entirely. ${ }^{111}$

Further arguments have been advanced to suggest that comitia were not called. In his speech to his troops, Cinna bemoans that the Senate removed his power without the People's consent ( $\chi \omega \rho \grave{\varsigma} \varsigma \dot{v} \mu \tilde{\omega} v) .{ }^{112}$ Merula would be deprived of his suffect consulship just a few months later, when Cinna returned with his army. It could be argued from this evidence that the Senate had peculiar power over magistracies in these chaotic months, with the ability to appoint and remove consuls without recourse to popular assemblies. ${ }^{113}$ This view must be treated with extreme caution. Velleius tells us that Merula abdicaverat, a view corroborated by Diodorus. ${ }^{114}$ If we synthesize our sources, we can say with confidence that Merula later abdicated at the Senate's behest. This was, after all, the standard process of removing consuls from office who had been elected during bad auspices. ${ }^{115}$ The Senate had indeed impinged on popular sovereignty in 87 , first by deposing Cinna, an obvious iniuria, ${ }^{116}$ and then by reinstating him at the expense of a suffect consul. But none of this proves that they took the extraordinary step of refusing to hold comitia.

Stifling competition was probably the extent of the Senate's and Octavius' impingement here. Merula was the preferred and, surely, only candidate. The reasons for choosing a man of Merula's status are easily ascertained. The Senate needed an unobjectionable man for the position. ${ }^{117} \mathrm{He}$ was an appealing option for both Octavius and the Senate. Merula's election effectively ensured a sole consulship for Octavius for the remainder

\footnotetext{
${ }^{108}$ App. B Civ. 2.9.

${ }^{109}$ That the elections of 59 were highly competitive has never been doubted. See, e.g., Cic. Att. 1.17.11. Cf. Evans $1991,122$.

110 See Luce 1958, 118-19, on Appian's 'carelessness' or 'ignorance' in discussions of constitutional matters.

111 See, e.g., Pompey’s election as sole consul in 52, which, as Ramsey 2016, 298-308, has shown, involved comitia despite the oblique wording of the majority of the sources.

${ }^{112}$ App. B Civ. 1.65. Cinna's rhetoric, however, focuses on his removal, not Merula's ascension.

113 So Morstein-Marx 2011, 266 n. 33. Cf. App. B Civ. 1.69-70.

${ }^{114}$ Vell. Pat. 2.22.2; Diod. Sic. 38/39.3. App. B Civ. 1.70, though implying senatorial initiative, is ambiguous. This despite Morstein-Marx's confidence that 'Merula appears to have been deposed again by a senatorial decision alone' (2011, 266 n. 33).

115 Cic. ND 2.11; Div. 2.74.

116 Vell. Pat. 2.20.3.

117 Katz 1979, 164, argues that the senatorial decision may have been an attempt to keep other potentially objectionable men out of the consulship. One might present the caveat that the suffect consulship offered less prestige than the consulship itself (see, e.g., Liv. 41.18.16).
} 
of the year and, in the Senate's interests, kept the peace. Having witnessed mass bloodshed in the streets of Rome, the Senate's interest was in the stability of the republic. Merula was chosen as the temperate colleague for the worrisome Octavius, who at least held the interests of the aristocracy at heart. Presumably the traditional taboos surrounding the flamen Dialis remained in place even after his ascension to the consulship, so he would do little in a practical capacity. ${ }^{118}$ The (s)election of the current flamen Dialis is striking: he was there to maintain a semblance of religiosity and legitimacy. ${ }^{119}$

Cinna, having fled the city with six tribunes, now hostis, was stripped of his consulship and his rights as a Roman citizen, a grave violation of the rights of the consulship and of the sovereignty of the People. ${ }^{120}$ Cinna sought an immediate solution, and raised an army of his own to win back his curule chair. At this point, Appian provides us with the only piece of dialogue ascribed to Cinna. ${ }^{121}$ Here he laments the illegitimate loss of his consulship,

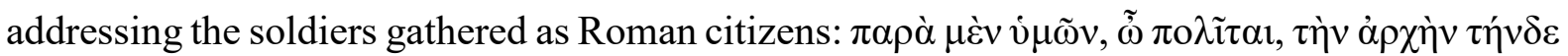

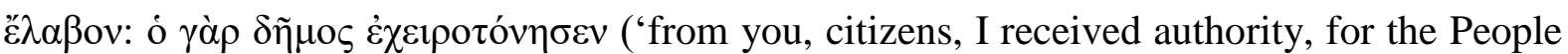

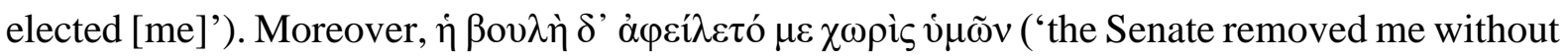
your consent'). In Appian's version, Cinna rhetorically presents himself as a legitimate consul addressing Roman citizens contione. The soldiers charged with besieging Nola followed him (as well they might) to protect the rights of the legitimate consul and to protect their rights as Roman citizens. Appian, usually hostile to Cinna, here paints him as the aggrieved, legitimate consul. $^{122}$

The ensuing events are familiar: Cinna, having toured Italian towns raising troops, along with Cn. Papirius Carbo, Q. Sertorius, and Marius, marched on Rome, just as Sulla had done several months earlier. A broad coalition of sorts formed in Italy of men with various grievances. ${ }^{123}$ Marius, declared a public enemy after his collusion with Sulpicius, had fled to Africa, and now returned with a vengeance with his veterans. ${ }^{124}$ Plutarch's accounts, for all their narrative embellishment, indicate that Marius had no meaningful previous dealings with

\footnotetext{
118 Taylor 1941, 114.

${ }^{119}$ Katz 1979, 164-5.

120 Vell. Pat. 2.20.3. This was, as Lovano 2002, 35, observes, 'incredibly harsh'. The official reasons for his expulsion were that he incited a slave revolt and because he had abandoned Rome in a time of crisis (a rather circular condemnation, since he had seemingly been forced out of Rome in the first place). See App. B Civ. 1.65. Katz 1979, 164-5 n. 8, suggests that Appian's chronology may be wrong, and Cinna was deposed from the consulship only after his raising of troops.

121 App. B Civ. 1.65.

122 See Morstein-Marx 2011, 266-78, for a compelling discussion of Cinna's rhetoric. Cf. Salmon 1967, 374. But see Hodgson 2017, 83-5, for a recent critique of Morstein-Marx's position.

${ }^{123}$ Gran. Lic. 16-17C catalogues his supporters.

${ }^{124}$ His adventures are recounted in sumptuous detail in Plut. Mar. 35-40.
} 
Cinna. ${ }^{125}$ Appian's narrative seems to corroborate this: this was the first time that they had

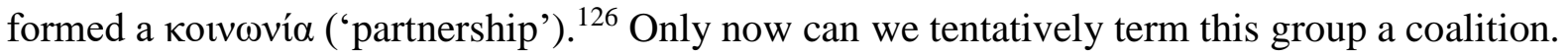
But they were united by diverse interests and grievances.

Cinna's was not a fractional or minority cause: he had Italians and Roman aristocrats alike in his ranks. Many from the Roman aristocracy now left Rome to join Cinna, possibly out of fear of the imminent invasion, or possibly because they genuinely supported Cinna's cause. ${ }^{127}$ This formidable force, comprising many from disaffected allied cities as well as the Marian exiles, closed in on Rome. ${ }^{128}$ They may have even enlisted the Samnites, who were still fighting against the Romans in the final throes of the Social War; the deal that was struck with them secured the ultimate end of that particular conflict. ${ }^{129}$ The battle lines were being drastically redrawn. Whereas Sulla's march on Rome was carried out in one swift, singular thrust, Cinna and Marius engaged in fully fledged civil war: the Senate and Octavius scrambled to defend the city, supplicating the hostile Pompeius Strabo who was (still) camped in Picenum with his army, awaiting an opportunity to win election to (or seize) the consulship for himself. ${ }^{130}$ Marius sacked Ostia; Cinna besieged Rome. Cinna had the superior military force. Strabo belatedly came to aid the senatorial forces, but died soon after. ${ }^{131}$ With the defenders' capitulation, Cinna would enter the city as consul once more. ${ }^{132}$ After negotiations, the Senate (eventually) restored Cinna to his consulship, with Merula compelled to abdicate.

Herewith ends a chronological history of the events prior to the so-called Cinnae dominatio. This chapter has dealt with some controversies in the constitutional history of this period. Critically, electoral norms remained intact until after Cinna's expulsion from Rome.

\footnotetext{
${ }^{125}$ Plut. Mar. 41.3. Cf. Sert. 5.1-3, which seems to indicate that Cinna had little to do with Marius before mid-87. Cf. Konrad 1994, 66-7.

${ }^{126}$ App. B Civ. 1.67.

${ }^{127}$ Cf. Flor. 2.9.11: ad nomen [Marii] tanti viri late concurritur ('many men from all around flocked to Marius'

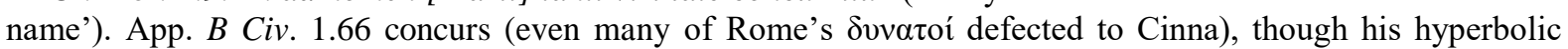

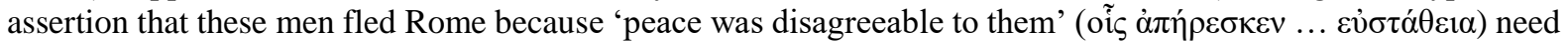
not be seriously entertained.

${ }^{128}$ App. $B$ Civ. 1.66. Vell. Pat. 2.20 .5 writes that Cinna amassed the equivalent of thirty legions in number.

${ }^{129}$ App. B Civ. 1.68. At the very least, the Cinnan forces made peace with the Samnites, while the Senate desperately (and unsuccessfully, due to Metellus Pius' unwillingness to compromise) tried to win their loyalty by granting them citizenship (Bispham 2007, 180-3). It is unclear whether the Samnites participated in the siege: see Lovano 2002, 40-1 with n. 52; Salmon 1967, 374-6. On the vexed question of the Samnites' political status in 87-81, see Bulst 1964, 326 (defective citizenship); Salmon 1967, 381 (largely unconcerned with citizenship); Keaveney 1982a, 500-1 ('virtually independent'); Badian 1958a, 240 (fully independent).

${ }^{130}$ Gran. Lic. 19C.

${ }^{131}$ Gran. Lic. 21C makes the claim, otherwise unattested, that Strabo and Cinna had secret dealings. But see Katz 1976b, 533-4 with n. 146, who doubts this story with good reason. See Katz 1976b, 333 n. 20, for a discussion of Strabo's death.

${ }^{132}$ For a fuller narrative of the civil war, see Seager 1994, 175-9, Lovano 2002, 38-45, and Katz 1976a, 334-6, provide good summaries, while our (often contradictory) primary sources include Liv. Per. 80, App. B Civ. 1.6871, Plut. Mar. 42-3, Sert. 5.5-6 Gran. Lic. 15-23C, Vell. Pat. 2.21., Oros. 5.19, Flor. 5.21.9-17.
} 
Merula's ascent to the consulship of 87 in Cinna's place is the first hint we have of an uncompetitive election. Sulla's march on Rome, though harrowing, had no impact on the Roman constitution, save the legislations that he would (legitimately) pass soon after. ${ }^{133}$ There is no hint of a slow destabilization of republican norms. What we get here is a violent jolt which disturbed the constitutional order. And the Cinnan revolution must be viewed in this context. In the following chapter, we will enter more controversial and less well-attested territory. Cinna's and Marius' actions on their return to Rome must dictate how we view the development of the Roman constitution at this time.

${ }^{133}$ Contra Flower 2010a, 92: 'it was Sulla's march at the head of his client army in 88 that overthrew republican government.' Cf. p. 93: 'the vestigial (or renewed) republic left behind by Sulla ... crumbled rapidly in the face of Cinna.' But see Morstein-Marx 2011, 260, for an alternative view. 


\section{CHAPTER TWO}

\section{TERROR AND THE QUESTIONABLE COMITIA FOR 86}

Modern scholarship is divided on the question of elections during the Cinnanum tempus. Thomas Mitchell has argued that 'the traditional electoral processes, a cornerstone of republicanism and oligarchic preeminence, were no longer functioning. ${ }^{, 1}$ Others have inferred from the limited surviving evidence that elections did take place during this period, and the republican constitution remained basically intact. Ernst Badian, for example, described the electoral irregularities during the 80s as 'natural and excusable', while Michael Lovano has alleged that 'there are indications that the Popular Assemblies continued to operate rather normally under the Cinnans'. ${ }^{2}$ The basic facts are clear: after the march on Rome in late 87 , the consulship was held by just a small clique of men. Conventions against continuatio and iteratio were cast aside, and no man objectionable to the consuls was elected to any high office. Of especial controversy is the method by which Cinna and Marius become consuls for 86 in late 87 , setting the foundation for the domination of higher magistracy by Cinna and his colleagues from 86 to 82 (to be discussed in Chapter Three).

First, it is necessary to provide a very brief outline of the extraordinary violence of late 87. The basic sequence of events in 87 is easily ascertained by Appian's narrative. Determining exactly when in the year particular events took place is less straightforward. Cinna may have been expelled quite early in the year, since he was able to enlist soldiers perhaps still wintering in Capua. ${ }^{3}$ Marius likely would have returned to Italy from Africa in the spring or early summer months when sailing conditions were favourable. ${ }^{4}$ Cinna and Marius and a diverse group of aggrieved and opportunistic men then besieged Rome with a large army. The siege was a protracted affair: Marius successfully captured and plundered several nearby seaward cities, sacking Ostia among others while Cinna was encamped by the Tiber. ${ }^{5}$ Accounts of these sacks vary, but doubtless many were killed in the capture of these cities. ${ }^{6}$ The defenders were

\footnotetext{
${ }^{1}$ Mitchell 1979, 78.

2 Badian 1962b, 57; Lovano 2002, 69. Cf. Mackay 2004, 126-7.

${ }^{3}$ App. B Civ. 1.65 .

${ }^{4}$ Plut. Mar. 41.2.

${ }^{5}$ App. B Civ. 1.67, 1.69; Plut. Mar. 41.

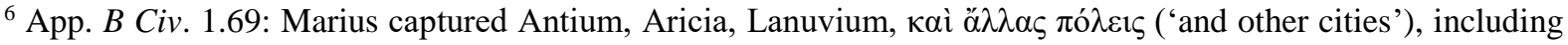
Ostia (1.67). Plut. Mar. 42.1, Flor. 2.9.12, and Liv. Per 79, all emphasize the cruelty of the latter capture (though Gran. Lic. 18C provides no detail of this). The cruelty of the sack may well have been exaggerated by later sources,
} 
woefully outnumbered: after some violent skirmishes, many from Rome began deserting to the besiegers, and the situation became hopeless. ${ }^{7}$ In consequence of the desertions, plague, and the impending famine, the Senate negotiated with Cinna and restored him to the consulship; he, Marius, and their army were admitted into the city.

Having been restored to the consulship and admitted into Rome, Cinna, together with Marius, launched a purge against prominent enemies, most of whom were important men in the aristocracy. ${ }^{8}$ Accounts of the massacre's severity vary greatly, and many sources endeavour to make the events of late 87 seem as lawless and bloody as possible. ${ }^{9}$ Nevertheless, we know of fourteen individuals who were deliberately targeted. Octavius (cos. 87), Cinna's colleague, was the first to be killed. Merula (suff. cos. 87) was put on trial and committed suicide. ${ }^{10} \mathrm{Q}$. Lutatius Catulus (cos. 102) did the same after he too was put on trial. ${ }^{11}$ Several others are known to have been put to death: M. Antonius (cos. 99), C. Iulius Caesar Strabo (aed. 90), L. Iulius Caesar (cos. 90), P. Licinius Crassus (cos. 97) and his namesake son, C. Numitorius, M. Baebius, P. Lentulus, C. Atilius Serranus (cos. 106), and Q. Ancharius (pr. 87). ${ }^{12}$ Others fled or were exiled. ${ }^{13}$ Because many of these men were prominent members of the aristocracy, their deaths doubtless caused much distress across all social classes. Although Sulla had not been party to Cinna's exile, he was declared hostis and his wife and children were forced to flee. ${ }^{14}$ Sulla's proconsular command was theoretically extinguished by this proclamation. The

but the realities of siege warfare make it distinctly unlikely that the post-siege sacks were carried out in a restrained, organized manner. On the post-siege scenario, see Ziolkowsi 1993, 69-91; Levithan 2013, $205-27$.

${ }^{7}$ App. B Civ. 1.69.

${ }^{8}$ Sources listed in MRR 2.46, esp. Cic. De or. 3.8-12. The most fulsome modern treatment of these purges remains Bulst 1964, 313-18. See Lovano 2002, 47-50, for a more condensed account.

${ }^{9}$ See, e.g., Val. Max. 2.8.7: L. Cinna et C. Marius hauserant quidem avidi civilem sanguinem ('indeed, Cinna and Marius had greedily drunk citizen blood').

${ }^{10}$ App. B Civ. 1.74; Vell. Pat. 2.22.2; Val. Max. 9.12.5; Flor. 2.9.16.

11 App. B Civ. 1.74 Cic. Tusc. 5.56; Diod. Sic. 38-39.4.3; Plut. Mar. 44.5; Flor. 2.9.15; Val. Max. 9.12.4.

${ }^{12}$ Listed in App. B Civ. 1.72. Cf. the exhaustive citations furnished by Lovano 2002, 48. Flor. 2.9.14 also mentions an otherwise unattested 'Fimbria', either an error - since C. Flavius Fimbria was the perpetrator of many atrocities (Liv. Per. 80; Cic. Rosc. 33; Val. Max. 9.11.2) - or a peculiar use of the ablative indicating his guilt. Cf. MRR 2.49 .

${ }^{13}$ A certain Cornutus was also targeted and narrowly escaped death, and an unknown number of people were

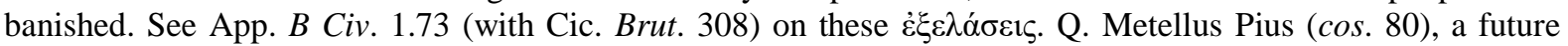
supporter of Sulla and senatorial negotiator during the siege of Rome (Gran. Lic. 23C; Diod. Sic. 38-39.2), fled to Africa, seemingly during the purge (App. B Civ. 1.80). A young M. Licinius Crassus fled to Spain (Plut. Crass. 4.1). Cf. Keaveney 1984b, 130-1.

${ }^{14}$ Cinna's hostis declaration against Sulla is mentioned six times by Appian (B Civ. 1.73, 1.77, 1.81; Mith. 51 (twice), 60). Cf. Bauman 1973, 289-93. There is disagreement as to whether Sulla's wife, Metella, was allowed to leave or had to flee for her life. Badian 1962b, 49, and Keaveney 2005, 71 with n. 15, maintain that she was forced to flee in 87, while Bennett 1923, 29-30, and Bulst 1964, 319, hold that she voluntarily departed in 86. This confusion arises from a contradiction within Plutarch's Sulla, which seems to place Metella's arrival in both early 86 (13.1) and 85 (22.2). App. B Civ. 1.73 corroborates the earlier date, likely proving that Metella left Rome at the time of Cinna's march on Rome. There is little reason to doubt Appian's statement that Sulla's family

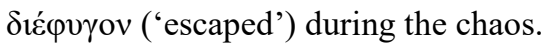


objective is clear: to delegitimize Sulla's Mithridatic command, assign it to Marius, ${ }^{15}$ and ensure no opposition could form. The extent of the flight or exile in late 87 is contested. ${ }^{16}$ Nevertheless, a great many from the aristocracy had already departed with Sulla for the lucrative war in the east. Doubtless many more unnamed individuals fled the violence, either to Sulla in the east or to 'convenient bolt-holes' in the western Mediterranean. ${ }^{17}$

The method and selectivity of the killings are striking. The heads of those of senatorial class were placed on the rostra as a grim and blatant threat to any who should oppose the new

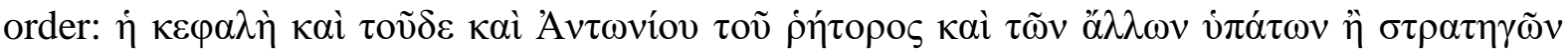

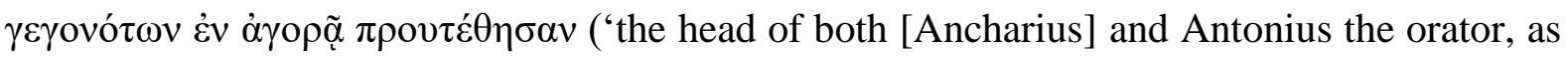
well as those of other consuls and praetors, were displayed in the Forum'). ${ }^{18}$ It was not a proscription in the technical sense - that would be a Sullan innovation - but the intent was similarly terrifying. There were doubtless more victims whose names have been forgotten, ${ }^{19}$ but the Marian terror would forever be remembered as a direct attack on members of the aristocracy: this was the moment when lumina civitatis exstincta sunt ('the shining lights of the civitas were snuffed out'). ${ }^{20}$ The purge 'was more drastic than anything that Rome had yet witnessed'. ${ }^{21}$ Some of our sources compare the soldiers' actions when entering the city to those of an army invading a foreign city: velut captam eam caedibus ac rapinis vastaverunt ('they laid waste to it with killings and plunder as though they had conquered it'). ${ }^{22}$ We must allow for some exaggeration in these accounts, but the panic caused by the inevitable indiscriminate killings and looting when an armed militia enters a city cannot be dismissed as pure fiction. ${ }^{23}$ Some of our sources paint Marius as a crazed figure, indiscriminately killing anyone who got

\footnotetext{
${ }^{15}$ Since L. Valerius Flaccus would succeed Marius in this command after the latter's death, there is no reason to doubt that Marius, as in 88, was intent on the Mithridatic command. See Badian 1958a, 241.

${ }^{16}$ See, e.g., Cic. Brut. 308; Plut. Sull. 22.1-2; Vell. Pat. 2.23.3; App. B Civ. 1.73; Sall. Hist. fr. 28. Badian 1962b, $52-4$, argues that 'the exodus of senators to Greece [is] clearly over-emphasized' (p. 49; cf. 1976, 51). But see Keaveney 1984b, 126-9, with an attempt to identify some of the men who fled to Sulla, dismissed by Santangelo 2007, 76 n. 38 as 'guesswork'. Many more would flock to Sulla much later, but many men definitely fled from Rome (to uncertain locations) in late 87.

${ }^{17}$ Balsdon 1965, 232.

${ }^{18}$ App. B Civ. 1.73. The wording is ambiguous enough to leave room for the possibility that other unnamed consulars and praetor(ian)s were treated in this manner. Cf. Cass. Dio fr. 102.9.

${ }^{19}$ The implication from App. B Civ. 1.71 is that many other nameless individuals were sought and slain, but only

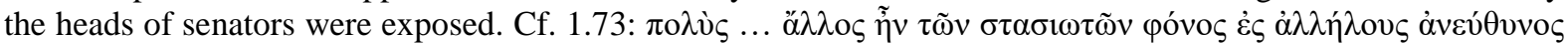
('there was much other unauthorized killing by the factions on one other'). Cass. Dio fr. 102.10 writes that many more people were killed in the chaos, even many whose deaths Marius did not order.

${ }^{20}$ Cic. Cat. 3.24. Cf. Sall. Hist. fr. 67.19; Cic. ND 3.80-1, Att. 7.7.7.

${ }^{21}$ Seager 2002, 16. Cf. 1994, 185: 'From a purely senatorial point of view the killings of 87 were worse than anything that had gone before'.

${ }^{22}$ Liv. Per. 80. Flor. 2.9.13-14 describes the sack as more severe than that of Carthage. Cf. Cass. Dio fr. 102.8.

${ }^{23}$ Carney 1970, 66 n. 284, for instance, observes that Marius likely allowed some degree of looting.
} 
in his way. ${ }^{24}$ This is simplistic. Certainly, his vengeance was bloody and cruel, and there was chaotic violence too. But it is important not to underplay how premeditated and calculated many of these killings were. Vindictive they may have been, but they were coldly strategic too. 25

Who was responsible for these murders? In an attempt to exculpate Cinna from the crimes, it has been alleged that most of the victims were enemies of Marius. Cinna, Badian alleged, 'had been an uneasy accomplice', having 'no relish for the slaughter' ${ }^{26}$ Indeed, they do not seem to have been particularly close allies. ${ }^{27}$ According to this narrative, the massacre was essentially Marius' bloody revenge against all his enemies. Indeed, vengeance may have been a major motive in some of the killings: Marius is known to have fallen out with Catulus over a decade earlier, ${ }^{28}$ and his enmity with Caesar Strabo is attested even if its origins are irrecoverable. ${ }^{29}$ Appian's narrative places the blame on Marius for the murders of Antonius and Ancharius. ${ }^{30}$ Cinna, meanwhile, sought the deaths of Merula and Octavius who had both usurped his consulship. ${ }^{31}$ The fact that Marius is known to have had previous contact with a few of the deceased figures proves little; there is little concrete proof to say that Marius ordered the deaths of the vast majority of the victims. ${ }^{32}$ It may be the case that many of the murders were the results of private grudges, though others may have been killed for more immediate reasons, such as actively organizing the defence of the city, or for an unattested role in Cinna's expulsion. ${ }^{33}$ Further, as will be discussed below, this was an effective way of terrorizing political opposition.

\footnotetext{
${ }^{24}$ Plut. Mar. 43.4-5. Cf. Val. Max. 9.2.2.

${ }^{25}$ Cf. Evans 1995, 169: 'his vengeance was more probably calculated than driven by insanity.'

${ }^{26}$ Badian 1962b, 55, identifies this tendency in which 'modern writers, according to the point they wish to make, have often followed [the ancient sources] to exculpate one of the two', before going on to attempt to absolve Cinna of responsibility. Cf. 1958, 240; 1964, 153. App. B Civ. 1.70 seems to indicate that Marius was the more assertive

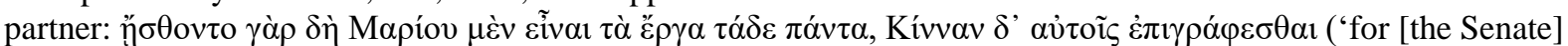
perceived that all these deeds - for which Cinna had claimed credit - were instead Marius' doing'), though this passage does not refer specifically to the murders.

${ }^{27}$ Plut. Sert. 5.1 implies some distrust between the two men, but it would be wrong to infer that the two men were completely at odds with one another on this slim evidence. See, e.g., Corbellini 1976, 154-6; Katz 1976 a, 336.

${ }^{28}$ Plut. Mar. 27.4-6. Cic. Tusc. 5.56 indicates that Marius desired his death.

${ }^{29}$ Diod. Sic. 37.2.12.

${ }^{30}$ App. B Civ. 1.72-3. But see Keaveney 1984b, 115-16, for a sceptical view of Marius' designs on Antonius' death.

${ }^{31}$ App. B Civ. 1.71, 1.74.

${ }^{32}$ Bulst 1964, 314-18, and Keaveney 1984b, 115-17, contra Badian's attempt to label the majority of the victims 'ex-Mariani' (1957, 338-42 with esp. n. 177; 1962, 55). Cf. Evans 1995, 197-8.

${ }^{33}$ See, esp., Keaveney 1984b, 117.
} 
The culprit is interchangeable depending on the writer's context. ${ }^{34}$ The cumulative effect is that the historical tradition tends to conflate the two main responsible actors for the killings. Cinna and Marius were, at the time, both perceived as the perpetrators - and perception matters. This makes the very question of assigning responsibility somewhat redundant: it is of little avail to speculate on who was 'the most vindictive of the victors'. ${ }^{35}$ The Roman People would not have made strong distinctions between the two men. Whatever the individual complexities, both Marius and Cinna were perceived as one and the same in the conquest. They were colleagues in the massacre, and would become colleagues in the consulship. They had formed a political alliance that had approved the killings. To the Roman People, both Marius and Cinna were the perpetrators. ${ }^{36}$ They had both been at the head of an invading army that had unleashed violence onto the streets of Rome, and had ostentatiously murdered many of the greatest living Romans.

This latter point is of particular importance. It is probably true that our sources exaggerate the scale of the killings. It is likely a falsehood, for example, that Marius and his

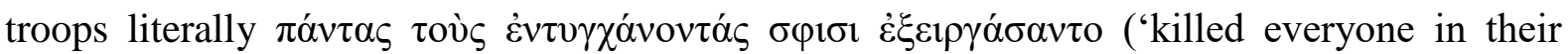
path'). ${ }^{37}$ But 'counting heads' is a flawed approach. ${ }^{38}$ There had been innumerable deaths during the seemingly endless violence at home and abroad since the beginning of the Social War. Yet there was something unique about the Marian-Cinnan purge which would have had a particularly damaging effect on the Roman psyche, to be remembered and reviled throughout the empire. ${ }^{39}$ The death of a consul was always a source of much distress across all classes: the Roman People tended to exhibit extraordinary deference to, veneration of, and solidarity with the senatorial order. ${ }^{40}$ To be sure, the perturbing memory of the murder of one consul by

\footnotetext{
${ }^{34}$ Marius: Plut. Mar. 43.4; Flor. 2.9.17; Cass. Dio fr. 102.8-11. Cinna: Cic. Att. 7.7.7; Phil. 11.1, ND 3.80, Tusc. 5.55. Both: Cic. Att. 9.10.3, Cat. 3.24; Val. Max. 2.8.7; Plut. Sert. 5.6. Carney 1960a, 115-16, observes that Cicero usually blames Cinna.

${ }^{35}$ Bennett 1923, 31, who concludes that it was Marius.

${ }^{36}$ Bennett 1923, 32: the killings may well have been 'ordered by a conference of leaders among whom Cinna and Marius held chief place', as described by Diod. Sic. 38-39.4.1, though Marius and Cinna were doubtless in control. Cf. Carney 1970, 67 n. 288, with sensible hypotheses against 'clear-cut attribution of responsibility'.

${ }^{37}$ Cass. Dio fr. 102.8. Plut. Mar. 43.3-6 too describes a wholesale and random massacre, while App. B Civ. 1.73

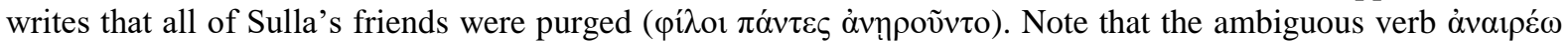
could refer to death or exile. Bennett 1923, 29 n. 27, suggests that Appian's ambiguity may be deliberate.

${ }^{38}$ Such is Butler's criticism $(2003,415)$ of Lovano 2002, 45-8, who follows Bennett 1923, 32-4, in downplaying the extent (or, at least, the psychological effect) of the violence. Bulst 1964, 314; Carney 1970, 66 with n. 286; and Markwitz 2014, 119-21, also have a tendency to understate the repercussions of the killings. Cf. Hinard 2006, 251, and 253 n. 37, for his corrective of Lovano 2002, 138.

${ }^{39}$ See, e.g., Luc. Phar. 2.99-133, esp. 11. 99-100: quis fuit ille dies, Marius quo moenia victor corripuit ('what a terrible day it was, when the victorious Marius seized the city!').

${ }^{40}$ See, e.g., Hölkeskamp 2010, 49-52, 107-24 et passim, esp. 118-20, 134-6, on 'the social coherence between the populus Romanus and its political class' (p. 135). Cf. Hinard 2006, 252, on 'la solidarité profonde qui unissait le populus à son élite.' Cf. Polyb. 6.51.6-8.
} 
another in the streets of Rome would endure for generations. Cinna's crudelitas here is frequently used by the historical traditional to characterize and simplify his political career. ${ }^{41}$ Not only had a consul died: many members of the senate, including six consulars, had been put to death. Even if the killings were smaller in scale than other recent perturbations, the manner of these deliberately selected murders would have had a particularly terrorizing impact on Rome's urban population across all classes. The presentation of the victims' heads on the rostra for all to see can only confirm this entirely deliberate act of state terrorism.

And state terrorism it was. A broad definition of state terrorism goes as follows:

(a) [T]here must be a deliberate act of violence against individuals that the state has a duty to protect, or a threat of such an act if a climate of fear has already been established through preceding acts of state violence; $(b)$ the act must be perpetrated by actors on behalf of or in conjunction with the state $[\ldots] ;(c)$ the act or threat of violence is intended to induce extreme fear in some target observers who identify with that victim; and $(d)$ the target audience is forced to consider changing their behaviour in some way. ${ }^{42}$

Though it is problematic to equate the res publica with a 'state' in the modern sense, Cinna, as the only living consul, was the man in charge of the government, and Marius was set to join him. There was a deliberate act of violence against a group of conspicuous individuals by actors representing the res publica, who set a terrifying (and conspicuous, by way of the display of severed heads) example to observers. In this way, they would induce the 'target audience', especially Rome's upper classes, to tolerate the new regime. ${ }^{43}$ This is not to overlook the practical realities behind these men's deaths: the regime now had the opportunity to seize their property, had settled personal scores, and could now proceed politically without opposition. ${ }^{44}$ But the manner of the violence goes far beyond functionality. These were actions for which terrorizing opponents was the desired end. Plutarch captures the climate of fear: $\dot{\rho} \imath \tau o v \mu \varepsilon ́ v \omega v$

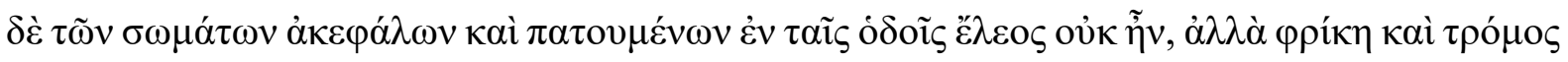

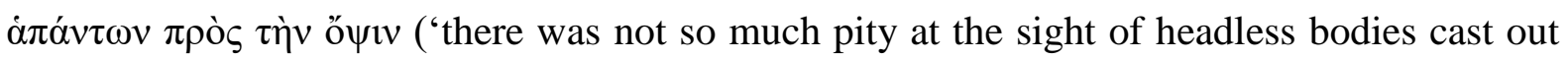
and trampled in the street, but rather shaking and trembling by everyone'). ${ }^{45}$

\footnotetext{
${ }^{41}$ See, e.g., Cic. Phil. 1.34, where Antonius' death is treated in synonymous terms with Cinna's political rule (dominatus).

${ }^{42}$ Blakely 2009, 15, modifying slightly the definition of Mitchell et al. 1986, 5.

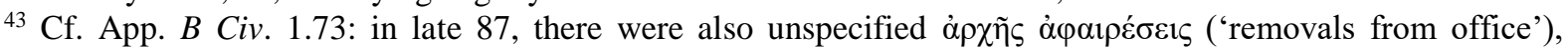
underlining the political motives of this purge.

${ }^{44}$ The removal of opposition is the central reason that Diodorus provides for the purge. See Diod. Sic. 38/39.4. Cf. Markwitz 2014, 120.

${ }^{45}$ Plut. Mar. 44.6.
} 
This is not a new observation. Shane Butler reminds us that 'the public bloodbaths that characterized the decade were at once executions and acts of terror, and as the latter they were aimed less at the victims than at their survivors. ${ }^{46}$ François Hinard has provided the most comprehensive discussion along these lines. The actions of Cinna and Marius during the siege of Rome and the subsequent purge had the effect of creating a 'climat de terreur'. In the war, Marius had sacked several Latian cities, setting a terrifying precedent for the inhabitants of Rome. ${ }^{47}$ This would have served both a practical and psychological purpose, both to cut off the grain supplies to Rome while inspiring terror in the people of Rome and Latium in general. ${ }^{48}$ Such were the strategies to compel Rome to surrender. But the actions immediately after the siege would have the greater impact, especially the ostentatious murder of some of Rome's greatest men. In order to understand the aftermath, the number of victims is of less significance than the psychological impact that it would have had on the urban population, enough to guarantee compliance with the new government.

A period of peace broke out in Rome following the Marian terror. ${ }^{49}$ This could be interpreted as satisfaction with the regime; Cinna may indeed have subsequently 'won the goodwill of the voters by implementing badly-needed economic reforms' ${ }^{50}$ But this is not the only reason for the apaisement. It is inconceivable that the Roman Senate and People would have embraced wholeheartedly the new state of affairs in late 87. Those responsible for the killings had successfully ensured conformity, at least for the time being. It is in this context that we need to comprehend the elections for 86. Once Cinna's and Marius' desire for the consulship was made apparent, it is hard to believe that anyone would have opposed them. Cinna was the only living consul, and, as we have established, the presiding magistrate held considerable sway over the election and had the final say over the candidates. He had but to accept Marius' and his own candidacy; no other aristocrats would have dared to canvass or submit a professio.

The chronology of late 87 cannot be determined with any degree of certainty. Although the elections were held late in the year not long after the capture, there must have been a period

\footnotetext{
46 Butler 2003, 415.

${ }^{47}$ Liv. Per. 80; App. B Civ. 1.69; Oros. 5.19.19.

${ }^{48}$ Hinard 2006, 249-50. The enlisting of slaves (App. B Civ. 1.69), and the general breakdown in traditional republican values, too, would have doubtless caused panic in Rome.

${ }^{49}$ Cic. Brut. 308: triennium fere fuit urbs sine armis ('it was a period of three years altogether without conflict').

${ }^{50}$ Lovano 2002, 69. Cf. Badian 1962b, 55.
} 
before and after the comitia where Cinna was sole consul. ${ }^{51}$ There was indeed a period of significant violence within the city, but this was apparently settled within a few days. ${ }^{52}$ Plutarch

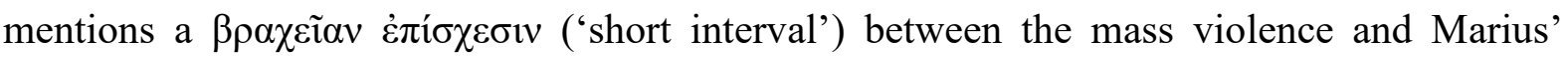
assumption of office on 1 January. ${ }^{53}$ We may infer from the scattered evidence that Cinna and Marius entered Rome around November or December 87, or perhaps even earlier. ${ }^{54}$ The compressed narrative transmitted to us may well be a product of the historians' abbreviation. By the first century, an interval (known as the trinundinum) of around twenty days was obligatory between the announcement of the election date and the holding of the comitia. ${ }^{55}$ If the trinundinum were to be observed, then Cinna was presumably sole consul for several weeks. The decision to put some of their enemies on trial also hints at a fairly drawn out process in late $87 .{ }^{56}$

The remaining days of 87 were a time when Rome was seemingly under martial law. It is impossible to be certain, but troops may not have been dismissed by election day as had been the case during the elections for 87 presided over by Sulla: there had been violent gangs in the streets, and they, in an extraordinarily violent reaction, were themselves massacred by Cinna's Gallic forces. ${ }^{57}$ Even if the army had been dismissed from Rome and the gangs suppressed by election day, the selective killings would have been fresh in the minds of the People (not to mention the mass public violence perpetrated by and on these gangs).

\footnotetext{
${ }^{51}$ There is no evidence to support Lanzani's claim that Marius was made suffect consul for the remainder of 87 $(1907,116 ; 1915,148)$. Nor is it possible that all the violence took place in early 86, as in Flor. 2.9.17, which contradicts all of our other major sources which recognize that Cinna was reinstated consul for 87, and most of the killings were exacted near the end of his consular year. See Bennett 1923, 39 n. 18; Gabba 1967, 201; Rawson $1987,167$.

${ }^{52}$ According to Cass. Dio fr. 102.11, the violence lasted five days.

${ }^{53}$ Plut. Mar. 45.1. The veracity of the Plutarch's narrative is made doubtful by the obvious anti-Marian tone, contrasting Marius' cowardice with Sulla's military prowess: the cessation of violence was allegedly caused by the erroneous story that Sulla was about to return from the east (so Carney 1958, 118; 1960c, 26-7; Passerini 1971, 190-1; cf. Plut. Sull. 12.3 on the impossibility of a Sullan return before 85). There are, however, two plausible alternative explanations beyond simple authorial invention: (i) Plutarch learned of this brief interval, and interpolated his own narrative onto this mundane fact; or (ii) Marius and Cinna fostered an atmosphere of fear, exaggerating the likelihood of a swift Sullan return, to justify their unconventional consulships (see pp. 478 below on this possibility). On chronological difficulties in late 87, see Twyman 1974, 274-5, who argues that Appian was unaware of the (often substantial) hiatus between election and assumption of magistracy.

${ }^{54}$ Bennett 1923, 36, postulates November. Lanzani 1907, 115-16, suggests that all of these events likely happened within a short window in December. Cf. Frier 1971, 586.

${ }^{55}$ Laid down by the lex Caecilia Didia of 98 (Cic. Phil. 5.8; Rotondi 1922, 335). On the particulars of the trinundinum, see Lintott 1965, 283-4; Astin 1962, 252.

${ }^{56}$ App. B Civ. 1.74.

${ }^{57}$ On the presence of troops in Rome in late 87, see App. B Civ. 1.74. The election immediately follows this slaughter in Appian's narrative. The Bardyaei, a gang numbering in the thousands, possibly on the employ of Marius, were allegedly guilty of numerous grotesque crimes in Rome following the sack, to the extent that Cinna and/or Sertorius ambushed them and other fugitives at night in late 87 (contra Bulst 1964, 314 n. 42) and slaughtered them. See Plut. Sert. 5.5, Mar. 44.6; App. B Civ. 1.74; Oros. 5.19.24. On the identification of this group and interpretation of the contradictory accounts, see, esp., Konrad 1994, 71-3; but also, Bennett 1923, 23 n. 112, 30; Sartori 1973, 159-62; Corbellini 1976, 156; Hinard 2006, 252-3.
} 
Around this time, presumably after the violence had concluded, the magistrates for the following year were chosen. There is disagreement over whether comitia were called. The only explicit mention of electoral proceedings comes from the Periochae: et citra ulla comitia consules in sequentem annum se ipsos renuntiaverunt ('and, without any comitia, they announced themselves consuls for the following year'). ${ }^{58}$ If we take this statement literally, the comitia centuriata was not called at all in 87 , and Cinna and Marius presumably just stood up in front of the crowd gathered in the Campus Martius and announced themselves consuls. Seldom, even in the declining years of the republic, is this claim made in such explicit terms. ${ }^{59}$ The accusation could be a simple result of Sullan propaganda, but it is worth exploring this phrase nonetheless, not least because it is our only source to treat directly of elections in this year.

Let us compare Appian's description of the same episode:

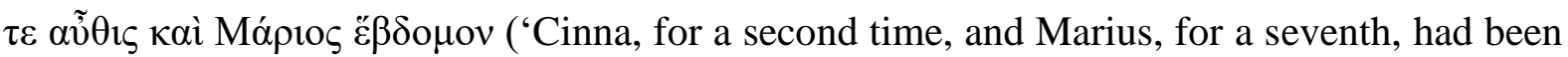

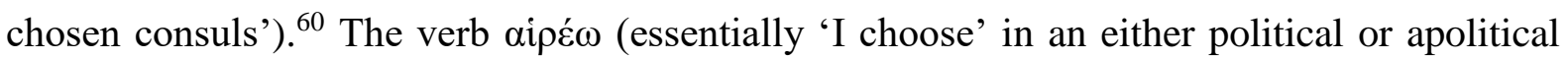
sense) is one of the standard verbs for describing an election. If Appian did believe that no elections were held at all, one would expect him to include the pronoun $\dot{\varepsilon} \alpha v \tau o ́ v$ as he would do later in his description of Cinna's election for 84 or in his brief excursus on Roman emperors. ${ }^{61}$ No agent is mentioned by Appian, as he sometimes does, ${ }^{62}$ but the implication is that an electorate of sorts made them consuls by way of comitia. Not that the verb is reserved for mentions of 'the constitutionally legitimate election of individuals to ... office': Appian deploys the same verb when referring to some constitutionally dubious Caesarian, triumviral, and imperial elections. ${ }^{63}$ But it is important to note that comitia were indeed called on almost all of these occasions. ${ }^{64}$ The reader of Appian would have probably gone away with the

\footnotetext{
${ }^{58}$ Liv. Per. 80.

${ }^{59}$ Suet. Iul. 76.2 is a rare exception: comitia nulla habuerit ('[Caesar] held no elections' for lower magistracies for 45). More on this below.

${ }^{60}$ App. B Civ. 1.75 .

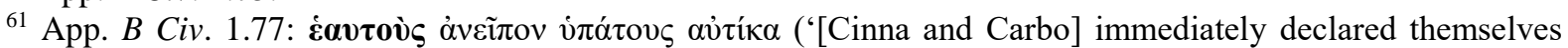

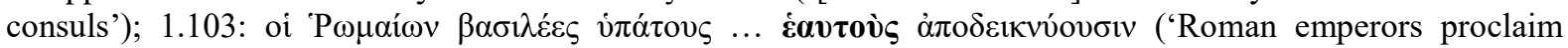
themselves consuls').

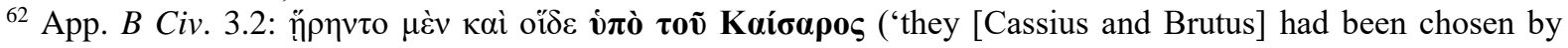
Caesar').

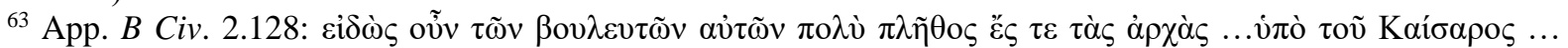

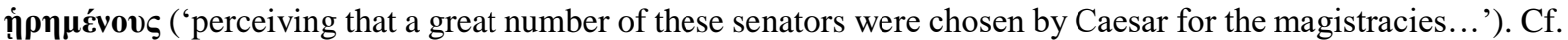
2.122 and 5.132 for ascension of Augustus to tribune for life by popular acclaim. A rare exception falls during the

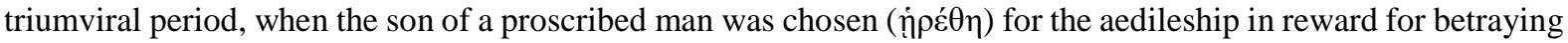
his father Annalis (4.18).

${ }^{64}$ These men were careful to maintain an impression of legal proceedings. Caesar, for instance, never fully transgressed republican iura to the letter: as Welch (1990, 58 n. 33) puts it, he 'compromised' republican mores without taking 'the more drastic step of completely overturning the comitia.' On elections under Caesar in general, see Yavetz 1983, 127-32; Sumi 2005, 54-7. The ceremony was seemingly held (that is, the comitia centuriata
} 
impression that comitia were held in late 87. Nevertheless, Appian can be quite careless when writing about constitutional matters, sometimes guilty of 'hastily abridging and epitomizing his sources, summed up in a few unhappy words what his source gave correctly at greater length. ${ }^{65}$ His wording on this occasion is highly suggestive, but not decisive in itself.

Plutarch, like Appian often ignorant of or uninterested in constitutional matters, in his patchwork of often contradictory sources, provides no suspicion of irregular elections. ${ }^{66} \mathrm{He}$

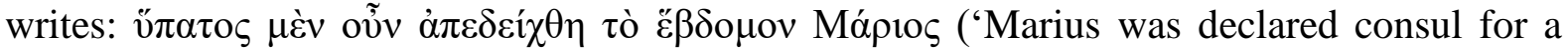
seventh time'). ${ }^{67}$ The verb $\alpha$ i to regular elections: for instance, it is employed by Plutarch to describe Marius' second election to the consulship. ${ }^{68}$ The renuntiatio is carried out by the presiding magistrate after a candidate has acquired the votes of the appropriate number of centuries. The verb gives little away about comitial proceedings, but that Marius was announced ( $\dot{\alpha} \pi \varepsilon \delta \varepsilon \dot{\chi} \chi \theta \eta)$ consul by the presiding magistrate (Cinna) seems to presuppose comitia. Plutarch's is an abridged version of events, but he gives the impression that Marius was duly elected. ${ }^{69}$

The confusion here may stem from the various historical traditions at play. Appian, despite his use of Livy elsewhere ${ }^{70}$ may well have opted for a completely different source for these events. This is not uncharacteristic: as Richard Westall has observed, 'Appian at most made episodic use of Livy tempered by one or more other sources. ${ }^{71}$ He clearly saw nothing untoward in his own principal source. Appian's and the epitomator's respective narratives of the Civil War are different enough to suggest that Appian did not refer to Livy's 80th book when constructing his narrative. Appian mentions more deaths during the purge in late 87 , but

\footnotetext{
was called), despite the arguments of Frei-Stolba 1967, 70-1. Cic. Fam. 10.32.2 does not necessarily suggest that the ceremony was cancelled in Gades by the local magistrate, as Frei-Stolba and Sumi (p. 286) argue, leaving their argument that Caesar similarly cancelled comitia on shaky grounds. On the triumviral period, when some magistracies were filled by appointment of the triumvirs, see Millar 2002, 242-8. It bears noting that mentions of triumviral nominations sine comitiis are by and large described by Cassius Dio, not Appian (pp. 244-5). Cf. Staveley 1972, 217-26. On Augustan elections, see Jones 1955, 9-21.

${ }^{65}$ Luce 1958, 110.

${ }^{66}$ On Plutarch and the Roman constitution, see Pelling 2002, 207-11. On Plutarch's sources for the Marius, see Carney 1960c, 27-8.

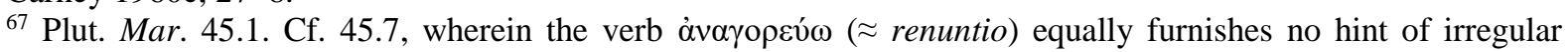
procedure. Cf. Yavetz 1982, 128-9, on the grammar of Roman elections in Greek.

${ }_{68}^{68}$ Plut. Mar. 12.1.

${ }^{69}$ Plut. Crass. 4.1 and Caes. 1.1 are inconclusive, describing excessive power in broad terms. Plut. Caes. 37.1, describing the election of Caesar and Isauricus to the consulship for 48, offers a useful comparison: $0 \pi \alpha \tau$ ov $\delta \dot{\varepsilon}$

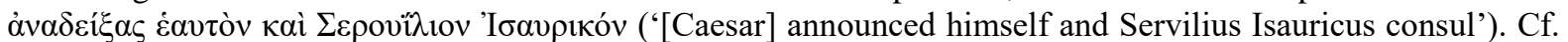
the analysis of Rawson 1994, 431: comitia were called in this year even if Caesar's preferred candidates (including himself) were chosen.

70 App. B Civ. 3.77.

71 Westall 2015, 157.
} 
none of those at the start of 86 mentioned by the Livian tradition. ${ }^{72}$ The original sources are impossible to recover with any degree of certainty. Livy's epitomator's main source was, of course, Livy. ${ }^{73}$ Livy's own sources may well have been Sisenna and Sallust. ${ }^{74}$ Plutarch's principal sources for the events of early 86 (and, with all probability, late 87) were a certain C. Piso and Posidonius, the latter of whom was in Rome at the time. ${ }^{75}$

So which tradition got the elections for 86 right? Just because Appian and Plutarch did not care about the comitia for 86 , it does not follow that their verbiage is inappropriate. The Livian passage, our only explicit mention of comitia, remains controversial. ${ }^{76}$ Some scholars have accepted the Livian expression as statement of fact. ${ }^{77}$ Nevertheless, it is possible, and is more commonly assumed, that the Livian expression is the epitomator's own inference, adding to a narrative according to which elections, highly irregular in that the two candidates were unopposed, did in fact occur. ${ }^{78}$ Livy and his epitomator, after all, do their utmost to discredit the Cinnan government. ${ }^{79}$

Doubtless, Cinna and Marius could have avoided the holding of comitia if they so desired. They were masters of the republic, having terrorized their opponents into submission. There are two ways of approaching this. On the one hand, there are some possible arguments in favour of a literal interpretation of the Livian passage. One might suppose that the two men saw no need to hold the comitia at all because they would win anyway, and doing so might

\footnotetext{
${ }^{72}$ For example, Appian, unlike Liv. Per. 80 and Plut. Mar. 45.3, provides no mention of the death of Sex. Licinius on 1 January.

${ }^{73}$ Interestingly, the epitomator seemingly had 'knowledge of a specific variant historical tradition' beyond Livy. See Bingham 1978, 392. Cf. Chaplin 2010, 456-8.

${ }^{74}$ The Quellenforschung of this period is both complicated and unresolved: Badian 1962b, 50, has rightly pointed out that there are (at least) two traditions behind the sources preserved to us, both pro-Sullan. However, Badian's confidence that the reasonably pro-Sullan Sisenna (see, e.g., Sall. Iug. 95.2) was an (or the) eyewitness of the Cinnanum tempus (cf. 1964c, 421-31) deserves caution (see, e.g., Balsdon 1965, 231). For further discussion on the sources for this period, see Mastrocinque 1999, 59-75; Valgiglio 1956a, 235-8; Gabba 1967, xxii-xxv; Morstein-Marx 2011, 271 n. 57; McGing 1986, 176-9; Westall 2015, esp. 143-6, 152-60.

${ }^{75}$ Plut. Mar. 45.8. Identification of Piso has proved elusive. Peter 1914, ccclxxx, suggests that he may be the

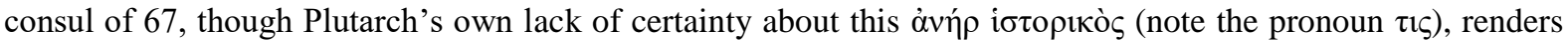
this hypothesis suspect.

${ }^{76}$ Markwitz 2014, 121-2, provides a useful summary of the contrasting scholarly views.

${ }^{77}$ Levi 1928, 191-4; Frier 1971, 588-9; Betti 1982, 181-3; Tondo 1993, 127; Cerami 2007, 393-4; Dart 2010, 103; Bispham 2007, 192. Meier 1997, 228 n. 134, encapsulates this view: 'Die Wahl geschah wohl in der Form der Acclamation.' Meier's analysis raises questions about what 'acclamation' would mean. Acclamatio is an anachronistic term: clamo and its cognates are never used in the republic to denote successful election. So FreiStolba 1967, 71: 'Diese Herleitung der Akklamation darf jedoch wohl nicht mit der Lage der Volksversammlung unter Caesar in Verbindung gebracht werden.' In German scholarship, terms like 'Akklamation' and 'Ernennung' are occasionally used, for which we find no republican terms: republican Latin was not equipped to deal with such irregular scenarios.

${ }^{78}$ See, e.g., Lanzani 1915, 147; Bennett 1923, 37; Valgiglio 1956b, 210; 1956b, 33 n. 1; Carney 1960a, 120; 1970, 70 n. 294; Gabba 1967, 203; Twyman 1974, 274; Seager 1994, 179; Lovano 2002, 49-50 n. 94; Hinard 2008a, 177.

${ }^{79}$ Seager 1977, 389. Cf. Chaplin 2010, 462.
} 
offer an opportunity for opposition to form. ${ }^{80}$ Additionally, during the triumviral period, magistrates were seemingly sometimes chosen by simple nomination by the triumvirs: not all autocrats decide to hold elections. ${ }^{81}$ Besides, in the last few weeks of 87 , Rome was a troubled place. Constitutional scruple was probably not the first thing on many people's minds.

On the other hand, and much more plausibly, we might suppose that the two men saw that it was expedient to hold the comitia to give their consulships some semblance of legitimacy, and to maintain the glory of Marius' seventh election. ${ }^{82}$ Despite their Machtpolitik, Cinna and Marius seem to have subsequently paid attention to broad legalistic principles on their entry into the city. ${ }^{83}$ Marius had insisted that the tribunes should repeal his banishment. ${ }^{84}$ The decision to repeal Sulla's electoral legislation of 88 and restore the influence of the tribunician college would seem altogether strange if comitia were to be set aside for choosing the magistrates and tribunes for $86 .{ }^{85}$ Merula and Catulus were put on trial to provide some semblance of legitimacy to the killings. ${ }^{86}$ Though the trials were never carried out owing to their suicides, these show-trials may have also been a means of demonstrating who was in charge of the law, an effective way of demoralizing one's political opponents, while making claims to legal authority.

Both social stability and religious scruple likely motivated them to hold the procedure. Any public ceremony required divine sanction, and Marius' sacrifice on the Capitol, though fitting awkwardly in Appian's chronology, may well be the traditional sacrifice upon assumption of office on 1 January. ${ }^{87}$ Perhaps more important, however, was the maintenance of social order after the perturbations of the siege. It is not inconceivable that there was enough

\footnotetext{
${ }^{80}$ One could argue that they had learned lessons from Sulla's march on Rome, who was consequently detested by people across all classes (Plut. Sull. 10.2). Of course, this could be interpreted differently: one might argue that, for the very reason the two men were assured of election, they saw no reason to cancel comitia (so van Ooteghem 1964, 319).

${ }^{81}$ See Millar 2002, 244-5, on nomination during the triumviral period.

${ }^{82}$ Lanzani's observation is particularly apt: the new consuls showed 'ostentato ossequio alle forme della legge e del diritto’ (1907, 118). Cf. Bennett 1923, 37; Valgiglio 1956b, 210.

${ }^{83}$ See Niccolini 1934, 234-6, for the laws known to have been passed through the tribunician college. Cf. Carney 1970, $62 \mathrm{nn} .273-4$, with arguments in favour of Marius' 'usual' observance of constitutional procedure. Bennett 1923, 64-5, lists a few other (less conclusive) examples of 'constitutionality'.

${ }^{84}$ Plut. Mar. 43.2-3 and Cass. Dio fr. 102.8 write that the impetuous Marius entered the city before the tribes had finished voting, and began the slaughter forthwith; Vell. Pat. 2.21.6 and App. B Civ. 1.69 mention only that his exile was repealed, casting serious doubt on the historicity of the former narrative.

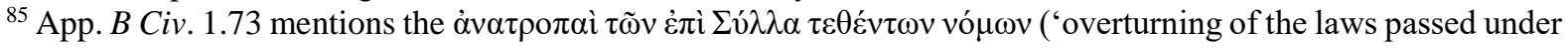
Sulla'). See Bennett 1923, 36, for the specific repercussions of these reforms.

${ }^{86}$ On the motives of the curious decision to put these two individuals on trial while approving the murder all other

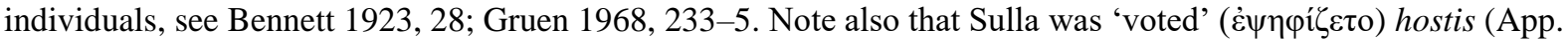
B Civ. 1.73).

${ }^{87}$ App. B Civ. 1.73. Cic. Vat. 23 would have us believe that, even in cruore Cinnano, religious procedure was followed. On religion and elections, see Staveley 1972, 149-50, 206-9.
} 
time remaining in the year for the conventional trinundinum to be observed, so that Cinna could announce the election day by contio well in advance of the vote. He would have good reason to observe this: canvassing was a crucial stage of any election campaign for both the prospective candidate's popularity among the masses and the maintenance of social order. As W.J. Tatum puts it, 'public order and sustained government depended to an extraordinary degree on the respect that a city's magistrates commanded. ${ }^{88}$ Intimidation was a short-term solution. Restoration of social stability would ensure political stability for the long haul. It was crucial for public stability that things be seen to be returning to normal.

Contradictions within the Livian account too may offer some clues. The curious paradox between the flagrantly unconstitutional citra comitia and the technical verb renuntio, never elsewhere deployed by the epitomator in this sense, should make us suspicious. ${ }^{89}$ If we take comitia to mean the process by which the magistrates were chosen, then the Livian phrase is nonsensical: in its traditional sense, the semantics of the verb presuppose comitia. Renuntiatio sine comitiis would mean nothing to contemporary Romans. Some sort of procedure must surely have been held to signal, in a way meaningful to the People, that these men would be consuls for the coming year. If not through comitia, how could the new magistrates communicate to the Roman people in an effective religious and political sense that they were the new consuls, in a society where comitia had been held without disturbance for centuries? The procedure of electing consuls was a crucial stage in signalling and reinforcing their authority. The phrase seems also to be indicative of the epitomator's own confusion. ${ }^{90}$ Livy's account (which I would imagine was not particularly detailed on the matter) doubtless mentioned a highly irregular procedure, perhaps accounting for his epitomator's confusion. ${ }^{91}$ But if the renuntiatio happened, then something strongly resembling comitia (qua comitia) must have been called.

\footnotetext{
${ }^{88}$ Tatum 2007, 115. Cf. Nippel 1995, 4-15.

${ }^{89}$ Ihne 1882, 334-5 n. 3, identifying the implausibility of the Livian story, suggests that the use of the preposition citra, never used by Livy himself in this way, signifies the epitomator's interpolation. Cf. Lanzani 1915, 147-8. This argument is not unreasonable. Livy's epitomator used this construction to emphasize absolute absence with characteristic exaggeration (cf. Per. 126). But it is not decisive. As Bennett 1923, 37 n. 10, points out, the verbal change 'could easily be the work of the epitomizer and prove nothing about the exact wording of the original.' Still, Ihne's analysis proves that the epitomator has significantly reworded the source text, rather than quoting it as he was wont to do (cf., e.g., Liv. 31.49.2 and Per. 31).

${ }^{90}$ Cinna's presiding over his own election is beyond question. Liv. Per. 80 also gets this detail slightly wrong, implying that both candidates presided over the procedure (se ipsos renuntiaverunt).

${ }^{91}$ See Bingham 1978, 392-401 for a survey of the statements made by the epitomator which have no foundation in Livy's earlier books. Cf. Jal 1984, xxxix-xlvii.
} 
A further possible clue may lie in the similarly worded account of the author of the $D e$ viris illustribus, part of the same tradition of epitomizing the likes of Livy. ${ }^{92}$ The anonymous author tells us that Cinna iterum et tertio consulem se ipse fecit ('made himself consul a second and third time'). ${ }^{93}$ This accords reasonably well with the account of the Periochae which also states that he made himself consul. But this detail need not surprise us: Cinna was the presiding magistrate and so, in a very real sense, he was making himself consul. Both this source and the Periochae formed part of the same historical tradition, and may have had a common source. One suspects that the Livian tradition preserved the story of an unusual procedure by which Cinna announced himself consul, all of which we know to be true. Whereas the author of the $D V I$ expanded no further on this matter, the epitomator wrongly extrapolated from this that comitia were somehow cancelled, loyally following and exaggerating the anti-Cinnan tradition. Livy, after all, portrayed Sulla as the upholder of Roman law in contraposition with Cinna. ${ }^{94}$ Livy may well have highlighted the unconventionality of Cinna's election; one can quite easily see how the epitomator would make the false inference that this entailed the cancellation of comitia.

If the procedure was held, the competitive spirit was dispensed with and the process was probably singled out by Livy as abnormal (hence the epitomator's confusion). This absence of competition was theoretically possible in Roman elections. Comitia were the sine qua non of the res publica. But competition was not the sine qua non of comitia: Augustus would later claim, however tenuously, that he was restoring the res publica even though he drastically reduced the possibility of intense aristocratic competition. ${ }^{95}$ There were doubtless some elections earlier in the republic for which the number of candidates was the same as the number of vacancies. ${ }^{96}$ Some examples from the declining years of the republic indicate that competition was not a prerequisite. Pompey and Crassus were (eventually) the only candidates

\footnotetext{
92 Sherwin 1969, 298-301.

${ }^{93}$ De vir. ill. 69.

94 Seager 1977, 388-9.

${ }^{95}$ See, e.g., RGDA 34. The republic was, in his version of events, restituta.

${ }^{96}$ Empirical evidence for unopposed elections earlier in the republic is hard to come by: Livy often mentions only the successful candidates in elections, and repulsae were mentioned only if germane to his purpose. For instance, just because M'. Acilius Glabrio was the only plebeian candidate for the consulship mentioned by Livy (35.24.4$5)$, we need not conclude that he stood unopposed. It is reasonable to infer that 'there were usually more candidates than could be accommodated' (Evans 1991, 123-4 with n. 75; cf. Broughton 1991, 1-4; Mouritsen 2001, 124). However, if, for whatever reason, the number of candidates equated to the number of positions, comitia would still have been held. For example, C. Mamilius Atellus, was elected as the only candidate for the curio maximus by popular assembly in 209 (Liv. 27.8.1-4; cf. Feig Vishnia 1996, 105-6; on voting procedure, see Lintott 1999, 184). Meanwhile, the consuls for 207 seem to have been elected unopposed (Liv. 27.34.15; cf. Develin 1985, 106; Rosenstein 1993, 327-8).
} 
for the consulship of $55 .{ }^{97}$ Pompey would later appear as the only candidate for his highly unconventional sole consulship of $52 .{ }^{98}$ Caesarian elections often seemed to involve the same number of candidates as offices. ${ }^{99}$ In these elections, the essential element of the res publica, the comitia, remained in place (for the most part), but the opportunity for aristocrats to compete for voters' affections was curtailed. Unfavourable candidacies were unlikely to be accepted. It would not be unreasonable to conceive of a similar situation in 87 . The number of candidates for all offices likely corresponded to the number of places to be filled. It is telling that every elected official during this time seemingly remained loyal or subservient to Cinna while the latter was alive. ${ }^{100}$

The procedural dynamics of the elections for 86 , then, must be hypothesized ex silentio. Taken literally, the phrase citra ulla comitia, to put it bluntly, does not seem plausible. The first few weeks after their march on Rome reveal tactics of both intimidation and legal(istic) scruple. Seizing power and ignoring constitutional procedures leave a government open to future claims of illegitimacy. Elections, however, cement political authority: they insinuate legalism and send a message to political opposition. Elections evince power and control in a way that a military putsch can never do. ${ }^{101}$ Even the most repressive authoritarian regimes and single-party systems today deign to hold elections. ${ }^{102}$ Even in the collapse of the republican system of the $40 \mathrm{~s}$ and $30 \mathrm{~s}$, comitia, although a sham, were usually called. Caesar and (especially) his great-nephew would later discern the political expediency in the continuity of the full republican process, made manifest by continuing to canvass for office and allowing

\footnotetext{
${ }^{97}$ Cass. Dio 39.31.1. Staveley 1954, 203-4 et passim, argues that, during interregna such as this, competition was curtailed by design. But, more recently, Ramsey 2016, 312-13 n. 53, has shown that more candidates could feature, and the more natural reading of Dio here is that rival candidates had the (theoretical) potential to run for the consulship this year.

${ }^{98}$ Ramsey 2016, 308, argues that comitia were still called as normal to confirm Pompey's election despite the misleading wording of our sources. Ramsey (p. 317) also adds the election of L. Aurelius Cotta and L. Manlius Torquatus to the consulship of 65 as another possible uncompetitive election. Cf. Ramsey 1982, esp. 124-5.

${ }^{99}$ The classic model for this is the election of C. Caninius Rebilus to the suffect consulship for one day at the end of 45, with regular procedure followed in the comitia centuriata (Cic. Fam. 7.30.1-3). On Caesar's commendatio, see Cic. Phil. 2.79. Cf. 2.80-4, indicating that, thanks to Caesar's commendatio, Dolabella ran unopposed in 43. Cf. Santangelo 2013, 276. Cic. Phil. 7.16 and Suet. Iul. 41.2 state that Caesar allowed the People the right to choose half of the magistrates, a backhanded curtailment of popular rights, doing nothing to increase opportunities for other aristocrats to run for office in the first place (so Yavetz 1982, 130-2). On the development of the commendatio Caesaris, see Jones 1955, 12; Levick 1967, 211-14 et passim; Staveley 1972, 221-3.

100 This picture of guaranteeing election to lower office for favourable individuals becomes clearer in later elections, discussed in Chapter Three.

${ }^{101}$ For a discussion of the logic behind modern electoral authoritarianism, see Schedler 2013, 141-74.

102 See Gandhi \& Lust-Okar 2009, 405-6 (and sources listed therein), on the tendency in (modern) authoritarian regimes to make 'overwhelming electoral victories serve as a signal to members of the regime elite that opposition is futile'. Cf. Hermet 1978, 15-16 on the legitimation value of such elections; and, more recently, Magaloni \& Kricheli 2010, 134-38, for an overview of the notion that 'autocrats holding elections signal their stability, not their democratic commitment' (p. 136).
} 
popular assemblies to ratify their (inevitable) consulships. ${ }^{103}$ As Geoffrey Sumi aptly puts it, describing Octavian's (likely uncontested) election to the suffect consulship in 43, 'these ceremonies still conferred power and prestige even if their integrity was suspect. ${ }^{104}$ Quite simply, the procedure mattered to Romans across all classes. What is more, Marius, in his insatiable drive for further influence and glories coupled with his craving for popular approval, surely would have seen no reason to taint his seventh consulship with such a processual anomaly.

Did Cinna and Marius seek further legal basis to cement their authority? Despite their broad adherence to electoral norms, there were unmistakable irregularities. Cinna's continuatio and, possibly, Marius' iteratio were unambiguously at odds with Roman electoral convention. Under normal circumstances, the presiding magistrate (and, probably, the Senate) would have objected to his candidature. But these were not normal circumstances: Cinna was the presiding magistrate and sole consul and could get tribunes to pass any decree he wished. With Cinna's and Marius' previous legalism in mind, it has been argued that they were granted a special dispensation from electoral rules in order to legitimize Cinna's continuatio. ${ }^{105}$ It is unclear whether such a dispensation was considered necessary. ${ }^{106}$ The comitia were both law-making and voting assemblies; their vote was law and would override previous legislation. ${ }^{107}$ Although an additional dispensation is not inconceivable, the vote of the People was theoretically sufficient to confirm the legality of his position.

There were other means by which Cinna would seek legitimation. It is entirely possible that Cinna followed Roman exemplary tradition and used the military situation to justify his continuatio: Rome was under threat from enemies (the hostis Sulla, Mithridates - it was all the

\footnotetext{
${ }^{103}$ Augustus' insistence on canvassing is telling. Cf. Suet. Aug. 56.1; Cass. Dio 55.34.2.

${ }^{104}$ Sumi 2005, 182.

105 So Brennan 2000, 382-4, 652. While his suggestions that Cinna may have sought a dispensation in late 87 are compelling, there is no good evidence for his hypothesis that a general dispensation had been in action since the start of the Social War. As made abundantly clear in Chapter One, there were no successful irregular elections to magistracies until this moment. Brennan's argument rests on the tenuous assumption that the consuls for 89 (L. Porcius Cato and Cn. Pompeius Strabo) were praetors in 91 or 90 (pp. 373, 383), thus were elected within the biennium. However, the terminology of our sources (Liv. Per 74 for Cato's praetorship in 90; Oros. 5.18.10 for Strabo's praetorship in 91) could just as easily refer to promagistracies, as he concedes at p. 373.

106 General setting aside of electoral rules are reported during the Hannibalic War (Liv. 27.6.7), and Scipio Aemilianus was granted a personal exemption for his irregular consulships (App. Pun. 112; Liv. Per. 56). Other instances are well-attested: e.g. Cic. Phil. 11.11, Man. 62; Asc. 58C; Liv. 10.13.10, Per. 50. Whether a solutio was required for any irregularity, however, is less than clear. For debate, see Brennan 2000, 652; Carney 1970, 35 n. 177; Passerini 1971, 48-51; Gabba 1957, 369; Luce 1970, 179; Sherwin-White 1956, 3-4.

${ }^{107}$ Liv. 7.17.12: quodcumque postremum populus iussisset, id ius ratumque esset; iussum populi et suffragia esse ('whatever law the People decreed most recently would have binding force; votes were also counted as decrees'). The point could be made that Marius' continuatio in the second century had undermined the customs that prevented it (see Billows 2009, 28). Still, Cinna's repetition of the consulship violated the spirit of the law, even if the point could be made that it adhered to the letter of the law.
} 
same), and continuity would ensure stability. ${ }^{108}$ Such may have comprised the avowed reasoning behind such a flagrant contravention of electoral mores, and may account for the strange (and flagrantly untrue) rumour in late 87 that Sulla's return was imminent. ${ }^{109}$ Rome needed its custos urbis once more. ${ }^{110}$ Mithridates, meanwhile, was not, as Badian has argued, 'as great a threat as the German hordes' faced by Marius in the 100s. ${ }^{111}$ The reality was that the political and military situation in 87 did not come close to matching that during the Cimbric or Punic Wars that underpinned the extraordinary consulships of Scipio and Marius. In these elections, the People were effectively choosing their preferred military commanders. But, crucially, the rhetoric of the day would likely make this comparison. The republic was imperilled just like in 105; it needed Cinna's continuatio, Marius' iteratio. As contemporary examples aptly demonstrate, by fostering a climate of fear, political leaders can soften their voters up to greater levels of autocratic government. The rhetoric of power often trumps reality.

But, from the historian's perspective, the reality of the situation matters as much as the rhetoric. To finish, then, I must stress the uniqueness of the situation in late 87 . The idea that the consuls for 86 were truly '[f]ollowing Marius' precedent' is fraught with problems. ${ }^{112}$ Badian has attempted to downplay the severity of Cinna's continuatio, presenting the notion that 'such innovations proliferate from precedent to precedent in grave emergencies: had the consuls been successful, no one would have remembered [the irregularities] against them, any more than Marius' continuatio was later held against him.' ${ }^{113}$ But one must be cautious in relying on precedents, even in the exemplary culture of Rome. The circumstances surrounding the rise of Cinna and his followers cannot be generalized in terms of another exceptional era. ${ }^{114}$ However Cinna framed it, there was no immediate threat to deal with. Cinna would remain in Rome for the whole year. ${ }^{115}$ Marius' continuatio two decades earlier may have offered some inspiration (or legalistic justification) for that which Cinna would achieve. ${ }^{116}$ But Marius'

\footnotetext{
${ }^{108}$ Cf. Cic. Man. 60 on the force of custom: the Romans should in pace consuetudini, in bello utilitati paruisse ('obey custom in peacetime, utilitas in wartime').

${ }^{109}$ Plut. Mar. 45.1.

${ }^{110}$ Cf. Cic. Cat. 3.24.

111 Badian 1962b, 57. Cf. Lovano 2002, 68: 'like Marius two decades, Cinna and Carbo could justify their continuatio in office as a military necessity.'

112 Badian in $O C D 377$.

${ }^{113}$ Badian 1962b, 58 n. 12.

114 The circumstances of Cinna's re-elections do not match the 'criteria' under which irregular elections could be tolerated enumerated by Hölkeskamp 1993, 24. Cf. Golden 2013, 120.

115 Pina Polo 2011, 245-6.

${ }^{116}$ Cf. Evans 1995, 164 n. 160: 'Marius' example was surely the driving force behind politicians' desires to gain a second, or even an early, consulship.'
} 
election for 86 must be understood in completely different terms from those two decades earlier.

Despite the Livian story, it seems reasonably likely that comitia were called in late 87. But now that Cinna and Marius were effectively in sole charge of the organs of state, they no longer held themselves strictly constrained by traditional electoral laws. They, for the moment, as a result of their strategy of intimidation, were the unassailable arbiters of Roman law, subsequently deploying the comitia and the quaestiones to maintain a semblance of legitimacy. A 'thin veneer of legality' it may have been, but it was effective. ${ }^{117}$ Appian's appraisal of the

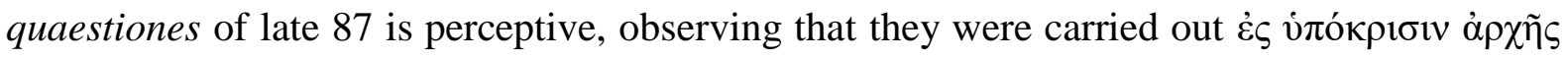
Ėvvó $\mu$ ov ('with the pretence of legal authority'). ${ }^{118}$ Their decision to repeal Sulla's reforms are particularly suggestive: they, not Sulla, were the champions of the republic. And without comitia, how could they persuasively claim to be the true republicans?

Nevertheless, it is impossible to deny that the elections for 86 were highly abnormal. ${ }^{119}$ Elections were generally unpredictable in Rome. ${ }^{120}$ Nihil est obscurius voluntate hominum indeed. ${ }^{121}$ The Roman People did not vote along party lines and occasionally chose two men for the consulship who were diametrically opposed. ${ }^{122}$ This intense competition was stifled in 87 , and, as we will see in the following chapter, would continue to be suppressed during the Cinnae dominatio. Had circumstances not intervened, the elections for 86 would have been highly competitive. ${ }^{123}$ But those, and only those, whom Marius and Cinna wanted to be elected entered office in 86. So Cinna and Marius began the year with significant control over the organs of the state, the latter readying himself to embark for the east.

\footnotetext{
117 Gruen 1968, 234.

118 App. B Civ. 1.74. A major topos of Appian's Bella Civilia is the question of legality and legitimacy, and the

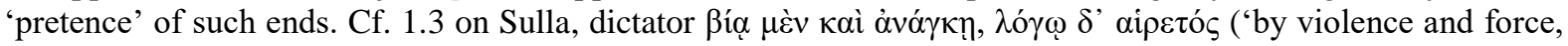

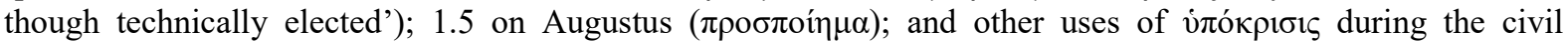
perturbations (e.g. 1.8, 1.99). Cf. the persuasive arguments of Cowan 2015, 188-202.

119 Contra Lovano 2002, 69: 'Popular Assemblies continued to operate rather normally under the Cinnans'; Carney 1960a, 120: 'There is no suggestion of irregular procedure over [Marius'] seventh consulship'.

${ }^{120}$ See, e.g., Pina Polo 2012, 63-4, 73.

121 To wit, 'nothing is more unclear than the will of men', from Cic. Mur. 36, which laments the caprice of voting assemblies.

122 The long-standing enmity between Bibulus and Caesar, consuls of 59, is the most famous example of this. Cf. Epstein 1987, 81.

${ }^{123}$ Metellus Pius (pr. 89) and Ap. Claudius Pulcher (pr. 89) were likely competitors. P. Servilius Vatia, after his repulsa the previous year, may have been planning another attempt. Pompeius Strabo was looking to take advantage of the chaos to secure a second consulship (Gran. Lic. 19C). Katz 1976a, 330-2, lists some further possible candidates. The list of eligible (and living) praetors from the late 90s until 89 (enumerated in MRR 2.17$18,2.20-1,2.25-6,2.33$ ) is suggestive. Cf. Badian 1958a, 239.
} 
THE ROMAN CONSTITUTION, 86-82

The nature of Rome's domestic politics during the Cinnanum tempus is notoriously difficult to characterize. These were years of unprecedented irregularities in the holding of magistracies. It is a time that defies generalization: the circumstances in 86 were quite different from those of 85 , and so forth. In this chapter, I will go through each of the annual comitia individually, and offer an interpretation of how Roman elections worked in this period. As with the elections for 86 , I contend that Cinna had grasped a dominant position in the republic and was able to deploy popular power through the comitia to consolidate his own power without cancelling this essential expression of popular power outright. Despite some assertions to the contrary, it would seem that comitia were held regularly in this period. Cinna nullified any possible political competition by doling out benefactions to members of the depleted aristocracy. Since he presided over his own re-elections, no one was equipped to stop him. After his death, the framework remained in place to continue to allow Sulla's enemies to be elected, even if their position was severely weakened.

In the purges of late 87, Cinna and Marius had successfully removed or silenced opposition. Regardless of the policies of conciliation that would follow Marius' sudden death, there was an environment of fear and paranoia in Rome at the beginning of 86. The new year was ushered in by a select few further political executions. ${ }^{1}$ These were all seemingly exacted with some regard for legal procedure: the possible delay of Q. Ancharius' death may be due to his holding of the praetorship until the changeover on 1 January. ${ }^{2}$ The consuls' insistence on observing superficial legal procedure once again indicates their desire to be seen as the legitimate government.

Terror and intimidation formed the foundation for the Cinnanum tempus, but they did not endure. It is commonly assumed that, owing to the hostile tradition, the violence stopped immediately with Marius' death, allowing Cinna to cut a clean break from Marius'

\footnotetext{
${ }^{1}$ A senator called Sex. Licinius (Liv. Per. 80; Plut. Mar. 45.3); a tribune of 87 Sex. Lucilius (killed by the new tribune P. Laenas) though this may have happened in late 87 since tribunes assumed office on 10 December (Vell. Pat. 2.24.2). Despite the similarity in names, Keaveney 1984b, 117, suggests that the diverging circumstances of both narratives may indicate that these were two distinct individuals.

${ }^{2}$ Appian tells us that Ancharius was killed by Marius while the latter was conducting sacrifices (B Civ. 1.73), suggesting that he died on 1 January around the time when the consuls were being inaugurated. Cf. Carney 1960b, 382-4; Rawson 1987, 167.
} 
vindictiveness and to establish stable government. Quid futuram fuit, si annum consulatus implesset, Florus asks ('what would have happened had Marius completed the full year of his consulship?'). ${ }^{3}$ As it happened, Marius died just two weeks into his consulship. ${ }^{4}$ This image of a Marius maddened by revenge and bloodlust may be somewhat facile. It would seem that the bulk of the murders were carried out in late 87, and the planned executions at the beginning of 86 seem to be the extent of the later killings. The ancient authors drew the connection between Marius' sudden death from an illness and the cessation of the killings, but this correlation may just be a convenient historical coincidence. Marius, after all, was still intent on Sulla's eastern command, not on additional murders. Plutarch's account clearly shows that there was a brief period between the final execution and Marius' death, as his physical health quickly declined. ${ }^{5}$

Nor is there sufficient evidence to say with any certainty that ' $[w] i t h$ Marius dead, the new government, universally recognized, could breathe a sigh of relief' ${ }^{6}$ Let us speculate on the two consuls' respective positions at the beginning of 86 . Marius, had he lived, would have made for the east come the end of winter. Cinna was almost certainly to manage affairs at home. Far from being a relief to Cinna, by no means a Marian partisan, Marius' death may have been a great inconvenience. Marius was, after all, an enormous and expedient source of political and military clout, offering Cinna a useful buffer against Sullan revenge. Had Marius lived, Cinna would have enjoyed effective control of Rome while his colleague confronted Mithridates and Sulla.

Nevertheless, despite the septuagenarian's death, Cinna found himself in a politically strong position at the beginning of 86 . New plans had to be laid. Comitia for a suffect consul were held very promptly. ${ }^{7}$ L. Valerius Flaccus, whose loyalty to the new government was confirmed by his betrayal of Ostia to Marius in 87, was made consul. ${ }^{8}$ Appian writes that

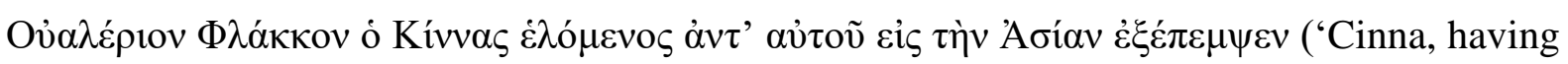

\footnotetext{
${ }^{3}$ Flor. 2.9.17. This tradition has been perpetuated by Badian 1962b, 55, and Bispham 2007, 195-6, among many others.

${ }^{4}$ The exact date varies in our sources, though 13 January seems the most likely. See Cic. ND 3.81; Rosc. Amer. 33; Liv. Per. 80; Plut. Mar. 46.5; App. B Civ. 1.75; Vell. Pat. 2.23.1; Flor. 2.9.17.

5 Plut. Mar. 45.2-7. Cf. Carney 1958, 117-22, for a daring attempt at reading the symptoms of Marius' final illness. Whether or not we choose to accept his hypotheses, Carney importantly highlights the physical, not the physiological, decline of Marius, and justly refuses to accept the ancient tradition that Marius, after displaying sane, calculated behaviour in 87 , all of a sudden succumbed to insanity in early 86 .

${ }^{6}$ Badian 1962b, 55.

${ }^{7}$ An inscription shows that Flaccus was already cos. suff. by 5 February (CIL X 8070).

${ }^{8}$ Gran. Lic. 18C. Though there remain doubts about the identity of the betrayer of Ostia, this Valerius is the only one we know of who could have been in such a position in 87 (see Bulst 1964, 320; Katz 1976a, 330 n. 13; despite the reservations of Bennett 1923, 14 n. 69). Otherwise, we know little about the man. Cf. Cic. Flac. 32, 77; Badian 1958b, 10; Lovano 2002, 56 n. 13.
} 
chosen Valerius Flaccus in [Marius'] place, sent him out to Asia'). ${ }^{9}$ His summary is reductive for two reasons. First, Flaccus was not merely a military replacement: before his departure, he initiated a badly needed debt reform ensuring the reduction of all debt to one quarter. ${ }^{10}$ Second, despite Appian's characteristically misleading phraseology, Flaccus was seemingly elected through the usual comitia. His wording may simply be proof that Cinna's preferred candidate was chosen. Flaccus was, however, almost certainly the only candidate. Contravention of electoral mos was again tolerated: Flaccus, like Cinna, was patrician. ${ }^{11}$ Due procedure was likely followed, giving apparent popular approval to the blatantly irregular situation where, for the first time in centuries, two patricians held the consulship together. That Flaccus was Cinna's preferred colleague is beyond dispute. Cinna endeavoured to win over some of the most important families surviving within Rome. ${ }^{12}$ Despite his consular immunity, he needed a broad church of support (or, at least, toleration). The suffect consul of 86 was closely related to his exact namesake, the consul of 100, who was made (or, less likely, re-established as) princeps senatus in the census arranged by Cinna. ${ }^{13}$ So, by the spring of 86 , Cinna had reached out to at least one of Rome's most illustrious families, and probably more besides. ${ }^{14}$

For his loyalty to the new government, Flaccus was rewarded with Marius' eastern command. He was a logical choice, having served in Asia as propraetor from $92 .{ }^{15}$ What was the ultimate objective of sending Flaccus to the east? Memnon writes that he was sent to share in the war with Sulla, and engage him in battle if the latter did not compromise with the Senate. ${ }^{16}$ Appian, meanwhile, writes that Flaccus was there to take Sulla's place, since Sulla

\footnotetext{
${ }^{9}$ App. B Civ. 1.75. Cf. Mith. 51.

${ }^{10}$ Dismissed by Vell. Pat. 2.23.2 as a lex turpissima. Sall. Cat. 33.2, however, indicates that the city's debt-laden residents desperately needed these radical economic measures. Cf. Bennett 1923, 40-1; Frank 1959, 231-2; and Lovano 2002, 72-3, on the dire economic situation facing Italy in 86.

${ }^{11}$ MRR Suppl. 19 tentatively suggests that this custom may have fallen into disuse by the first century. Even if this is the case, this move was likely to be viewed as unconventional.

${ }^{12}$ Cf. Badian 1958a, 242 n. 1; Lovano 2002, 56-7.

${ }^{13}$ Liv. Per. 83. There is some disagreement over whether Flaccus was made princeps in the lectio of 89 or 86. The position was vacated in late 89 or early 88 by death of M. Aemilius Scaurus (cos. 115). Thus Tansey 2003, 383 , has argued that the censors of 89 , during their defective census of $89 / 8$, appointed Flaccus as Scaurus' successor. But it is worth stressing that the lectio traditionally preceded the census, so the appointment of the princeps would have been made near the beginning of 89 . Moreover, in 89 , no full account of the citizen body was made (Cic. Arch. 11), possibly indicating that the lustrum was completed comparatively early. In short, by Scaurus' death, the censors may well have already resigned (cf. the more neutral positions in Tansey 2000, 1920; Rafferty 2011, 13-15). See Suolahti 1963, 26-30, and Brunt 1971a, 537, on the variable duration of the censorship.

${ }^{14}$ Cultivating the Valerii Flacci may have been a calculated move to ensure the support of C. Valerius Flaccus, who had at least two legions across the Alps. See Badian 1958b, 11-15; Brunt 1971a, 441.

${ }^{15}$ MRR 2.18-19. Cf. Badian 1962b, 56; Bulst 1964, 320. Frier 1971, 587-8, unconvincingly argues that Flaccus was an odd choice for this position, following App. Mith. 51, which erroneously states that he was ó $\pi \varepsilon 1 \rho \circ \pi$ ó $\varepsilon \mu$ o $\varsigma$ ('inexperienced in war').

${ }^{16}$ Memn. 24.1J.
} 
was a hostis and (theoretically) had no right to command troops. ${ }^{17}$ Neither version of events seems wholly plausible. Cinna and the Senate unlikely held the naïve expectation that Flaccus would defeat Sulla in battle, or that Sulla's five legions would defect to the legitimate consul and his much smaller army. Flaccus was accompanied by a mere two legions. ${ }^{18}$ Bennett's hypothesis is much more convincing: Flaccus was to attack Asia directly where Mithridates was weakest, thus bringing the war to a speedy end while Sulla was otherwise occupied in Greece. In this way, Sulla's claim on any glory might be diminished. ${ }^{19}$ In fact, this came very close to happening when Fimbria took command of Flaccus' army in $85 .^{20}$

This episode matters to us because it has implications on the extent of Cinna's influence over the Senate and foreign affairs in mid-86. Was it he or the Senate who gave Flaccus these orders? Keaveney has argued that this episode is proof of senatorial initiative at this early

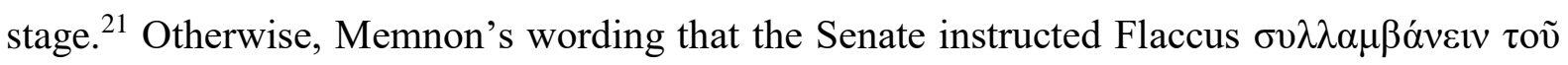
$\pi \mathrm{o} \lambda \varepsilon \dot{\mu} \mu v$ ('to assist in the war') - that is, to cooperate with Sulla - would seem odd, given that Cinna had recently declared Sulla hostis. ${ }^{22}$ His account explicitly puts the Senate in charge of negotiations. But this is a problematic source from which to deduce that the Senate was in full command of foreign policy. Memnon is unconcerned with domestic affairs with Rome, and his narrative describes only the tension between Sulla and the Senate. Cinna is never mentioned by Memnon. Keaveney's argument relies on a selective reading of Memnon, who claims that the Senate instructed Flaccus to fight Sulla immediately if the latter did not conform. ${ }^{23}$ Neither negotiating with Sulla, effectively demoting him to Flaccus' subordinate, nor engaging him in

\footnotetext{
${ }^{17}$ App. Mith. 51.

${ }^{18}$ App. Mith. 51. Keaveney 1984b, 133 n. 129, argues that the lack of troops sent speaks more to the weakness of Cinna's position in Italy than naïveté. But it more likely stems from a lack of desire for further warfare and the necessity of disbanding Italy's war-weary legions (see Brunt 1971a, 440-1; 1988, 462). Civil war with Sulla would only become a pressing concern late the following year.

${ }^{19}$ Bennett 1923, 45-6. Lovano 2002, 98-9, follows his argument.

${ }^{20}$ Plut. Luc. 3.4-7 and Gran. Lic. 26C indicate that Fimbria had pushed Mithridates to the brink of absolute defeat, and only Lucullus' refusal to collaborate with Fimbria and Sulla's dubious cooperation with the Pontic king allowed the latter to escape. Cf. Badian 1958a, 272 with n. 3; McGing 1986, 130-1. There is no room here to discuss the tribulations of Flaccus' doomed expedition. He was weakened by shipwrecks and desertions on his way to Asia, culminating in betrayal by his quaestor Fimbria. Fimbria took command of the army in Asia with some success. For further discussion, see, e.g., Katz 1972, 142-9; Lovano 2002, 99-101; and especially the revisionist account of Lintott 1976, 489-91.

${ }^{21}$ Keaveney 1984b, 133, expanding on the hypotheses in Meier 1997, 233. Cf. Seager 1994, 181.

${ }^{22}$ Memn. 24.1J. Although the declaration was likely more driven by Marius than by Cinna, there is no doubting Cinna's and Sulla's virtually irreconcilable enmity, despite the doubts expressed by Bulst 1964, 319.

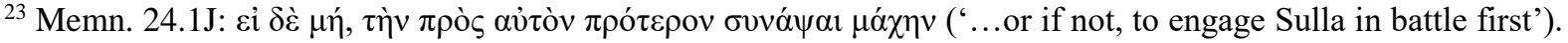
Keaveney 1984b, 133, and Steel 2013, 99, suggest that Fimbria was Cinna's plant in the army to ensure that his bidding was done. It is of course likely that Fimbria, an amicus of Marius, was more sympathetic to Cinna than Flaccus was (though Flaccus owed a debt of gratia to Cinna for securing him the consulship), but this does not presuppose a conspiracy between Cinna and Fimbria to scupper senatorial negotiation and to destabilize Flaccus'

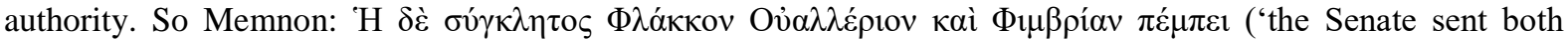
Valerius Flaccus and Fimbria...').
} 
battle with a mere two legions was a feasible approach. If Memnon did get their initial strategy right, then it is clear that they never acted on it: no envoys were actually sent to Sulla and he was certainly not attacked. ${ }^{24}$ Badian's deduction that there is no clear evidence of 'division between Cinna and the Senate' in 86 is therefore substantially correct. ${ }^{25}$ They may have had differing motivations: the Senate may have desired reconciliation with Sulla more than Cinna. But it was in both parties' interests to send Flaccus directly to Asia.

Furthermore, it is unlikely that such overtures would have been made to Sulla at this early stage. Flaccus the princeps is only recorded as having sought conciliation with Sulla a year or two later, when the Senate's insubordination would become more pronounced. ${ }^{26}$ This argument may be taken further: it is unlikely that any prominent aristocrats at Rome would have resisted Cinna's demands in 86. By granting them these opportunities, the new suffect consul, the new censors, and thence the new princeps senatus, owed him a significant debt of gratia, whether they liked it or not. This Flaccus, the man made princeps by this census, was the same man who was elected as $i \pi \eta \rho \varepsilon ́ \tau \eta \varsigma$ ('puppet') of Marius to the consulship of $100 .{ }^{27}$ Cicero, weighing up his options during the civil war of 49, ponders if idem fecero quod in Cinnae dominatione Philippus, quod L. Flaccus, quod Q. Mucius ('I should do the same as what Philippus [the censor], L. Flaccus [the princeps], and Q. Mucius [the pontifex] did during the Cinnae dominatio'). ${ }^{28}$ That is, should he remain within Rome and side with the conqueror (Cinna/Caesar), ${ }^{29}$ at least until the tide turns $?^{30}$ The loyalty of these men did not have to be entirely sincere, but they were compelled to conform nonetheless.

We get a similar situation in the election of the censors for $86 / 5$. Cinna's hand was not forced in its exaction. ${ }^{31}$ As we have seen, Cinna had not abandoned legal principles, and seemingly had no intention, nor capability, of acting as sole ruler. He desired the lustrum and census to fulfil his promise to enrol the Italians in the thirty-five tribes, but there were few men eligible. L. Marcius Philippus (cos. 91) and M. Perperna (cos. 92) were chosen censors

\footnotetext{
${ }^{24}$ Plut. Sull. 20.1, App. Mith. 51, and Memn. 24.2J concur that Flaccus (or representatives thereof) and Sulla never

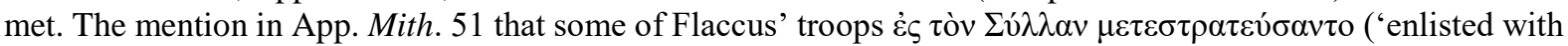
Sulla') may be harmonized with Plut. Sull. 15.4, in which Flaccus' advance guard led by a certain Hortensius, isolated by storms and imperilled by enemies nearby, were left with little choice but to defect to Sulla. Cf. Keaveney 2005, 77.

${ }^{25}$ Badian 1962b, 57.

${ }^{26}$ Liv. Per. 83.

${ }^{27}$ Plut. Mar. 28.5.

${ }^{28}$ Cic. Att. 8.3.6.

${ }^{29}$ Si restitero et fuerit nobis in hac parte locus ('If I should stay and if [Caesar] should allow us a place in this faction...').

${ }^{30}$ Cum sit necesse servire tempori et non amittere tempus cum sit datum ('[like Philippus], when it is necessary to serve the time and not to waste time when it is given').

${ }^{31}$ Taylor 1960, 105, 311; Evans 1997, 82-3. Contra Bispham 2007, 196.
} 
(presumably, again, the only two candidates), men selected as much for their eligibility as their acceptability: they were two of the four available consulars that we know of, so Cinna did not exactly have a wealth of options. ${ }^{32}$ The comitia centuriata must have been called early in the year, probably presided over by Cinna after Marius' death, to confirm the election of the censors. $^{33}$

Bispham has interpreted this census as evidence 'that Cinna had been forced to compromise [on the issue of Italian enrolment] by the Senate. ${ }^{34}$ I would like to offer a slightly different interpretation. The fact that one of the censors, Philippus, was historically hostile to enfranchisement is insufficient evidence that the Senate was bossing Cinna around thus at this early stage. ${ }^{35}$ Cinna and Marius had also both fought against the Italians since then. And, as the only living consul, it was for Cinna to call and preside over the comitia. It was not a case of Cinna being forced to compromise, but of Cinna attempting to gain supporters and win influence over them. Bispham's conclusion that the census represents an 'uneasy cooperation', a compromise, between the Senate and Cinna is accurate. But it was Cinna who took the initiative. There is no sign of Cinna's subordination to the Senate.

We can discern many reasons why Cinna would have wanted to carry out a census. The census necessitated a lectio senatus, allowing the opportunity to remove political opponents from positions of auctoritas. We know of only one man struck off by the lectio, Philippus' own uncle, Ap. Claudius Pulcher, a prominent adherent of Sulla who had been deprived of his imperium by Cinna during the perturbations of 87 and exiled. ${ }^{36}$ It is fair to assume that any other men hostile to Cinna or associated with Sulla (including Sulla himself) were excised from the Senate. The consul was also keen to provide a clean break from recent troubles: as Bispham states, 'the census could symbolize the renewal of the res publica through the completion of a lustrum: a good omen for a fresh start' ${ }^{37}$ After the perturbations of 87 , there could be no more effective way of restoring social and religious order. And, finally, having been exiled for the Italian cause, Cinna intended to enfranchise them into the thirty-one rural tribes. A census was the only way by which this could be carried out.

\footnotetext{
32 Our sources are mostly muted on their censorship: Val. Max. 8.13.4; Cic. Dom. 84; Verr. 2.1.143; Plin. HN 7.156; Cass. Dio 41.14.5. Cf. Badian 1962b, 52; Brunt 1965, 109.

${ }^{33}$ Censorial elections were presided over by one of the new consuls once their consular year had begun, and assumed office as soon as the election was announced. See, e.g., Liv. 24.10.2; 32.7.1; 39.41.5. Suolahti 1963, 739, provides a useful summary of the process of electing censors.

${ }^{34}$ Bispham 2007, 196. This strikes me as an unnecessary revision of the perspective of Taylor 1960, 105.

${ }^{35}$ On Philippus' hostility to the Italian cause, see Cic. De or. 1.24. Further sources in MRR 2.20. Cf. Harris 1971, 236; Kendall 2008, 467-8.

${ }^{36}$ Cic. Dom. 83-4. Keaveney 1984b, 118, argues that he fled to Sulla.

${ }^{37}$ Bispham 2007, 196 n. 167.
} 
But disagreement remains over whether the censors actually carried out these instructions. On the face of it, the timely census of 86 would seem to be the key to unlocking the Italian problem at last, fulfilling Cinna's promise of full citizenship throughout Italy. A number of factors stand in the way of this hypothesis. As mentioned, Philippus, one of the chosen censors, had been enormously hostile to Drusus' campaign of Italian emancipation in 91. In addition, the census figure of 463,000 preserved for us by Jerome, if correct, would seem too low if a full census had included all Italian adult males. ${ }^{38}$ Finally, Livy's epitomator, rightly or wrongly, tells us that, in 84 , novis civibus senatus consulto suffragium datum est ('suffrage was given to the new citizens by way of senatus consultum'). ${ }^{39}$ At first blush, then, the census of $86 / 5$ failed at enfranchising the Italians. ${ }^{40}$ However much he sought Italian enfranchisement, so the argument goes, Cinna was doomed to be scuppered by intransigent censors.

Nevertheless, persuasive arguments have been put forward suggesting that the Italians were, at the very least partially, integrated into the rural tribes by the census. The low census figures (presuming that they are true) may not necessarily be indicative of a refusal to count the Italians. It is entirely possible that some Italians from lower classes were not counted, neglecting to make the arduous trek to Rome. ${ }^{41}$ Some areas, Umbria and Etruria in particular, received a distinctly better deal from the tribal allocations that took place around this time, suggesting a certain selectivity in the conduct of the censors. Regions that had been loyal to Rome during the Social War fared better than rebellious regions. ${ }^{42}$ Moreover, it has been convincingly argued that the senatus consultum of 84 for the suffragium of the new citizens refers to a mere confirmation of the 'existing rights of the new citizens to vote in the thirty-one rural tribes. ${ }^{43}$ The census of $86 / 5$ did, in fact, begin the process of enfranchising the new citizens. After all, no census would be held in Rome for nearly two decades, without which new voters could not be admitted to the roll. ${ }^{44}$ Distribution was uneven and incomplete, perhaps

\footnotetext{
${ }^{38}$ Jer. Chr. $151 \mathrm{H}$. Thousands of Romans and Italians had, of course perished during the wars and plagues of 9187. But the total male population cannot have been as low at 463,000 , not least because the census of 70/69 transmitted a figure almost double that. Cf. Brunt 1971a, 92-3. Census figures, however, make for problematic evidence: the number transmitted to or by the late imperial chroniclers may be wrong. In addition, many men (especially soldiers away on duty and lower-class individuals) may not have been counted.

${ }^{39}$ Liv. Per. 84 . The Senate did not have the power to do this, but there may have been a popular vote acting on this $S C$ left unmentioned by the epitomator.

${ }^{40}$ This is the more common interpretation of the evidence: see Harris 1971, 230-6; Brunt 1965, 107-9; Badian 1962b, 56 n. 8; Keaveney 1987, 183-5. Cf. Brunt 1988, 462: these men were appointed censors 'perhaps with the very object of frustrating the effective enfranchisement of the new citizens'.

${ }^{41}$ So Taylor 1960, 105-6.

${ }^{42}$ Harris 1971, 236-50.

${ }^{43}$ Bispham 2007, 193-4.

${ }^{44}$ Harris 1971, 233, argues, without evidence, that Sulla conducted a census as dictator in 82/1. But see Bispham 2007, 194 n. 160.
} 
speaking as much to the enormity of the task at hand than the intransigence of the censors. But Cinna's intention, at least, in calling the census was full enfranchisement. Whether his wishes were carried out to the letter is less clear: it may well be that the new citizens were assigned to the tribes, but most, aside from very wealthy Italians, remained unenrolled in the centuries until the next census a decade later. ${ }^{45}$ In any case, the issue of fair distribution across the tribes would disappear entirely by 84 .

These episodes provide some indication of the balance of power in 86 . By the end of the year, Cinna had gathered some support. Even if a number of former rebels were disadvantaged by the ongoing census, Cinna could command support from Italian communities, particularly in Etruria. Cinna's successful attempts to call on Italian leaders for troops following the news of Sulla's impending return to Italy in 85 can be taken as evidence of the willingness of the Italians to serve their benefactor: we are told that the two consuls for

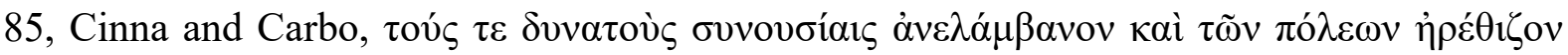

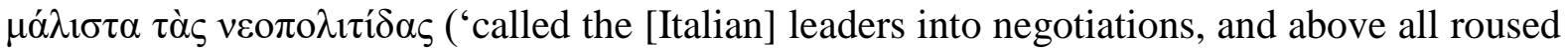
up the new citizens of the towns'). ${ }^{46}$ If Cinna had not entirely fulfilled his promise by 85 , many of the new citizens were evidently willing to overlook this fact. Their loyalty and gratitude remained largely with Cinna. ${ }^{47}$

Furthermore, like Marius in the 100s, Cinna enjoyed support from many in the equestrian order at Rome. ${ }^{48}$ Owing in part to the absence of many great men, many novi homines flourished in politics. ${ }^{49}$ The murder of well over a thousand equites, and a smaller number of senators, by Sulla during the proscriptions indicates a decent backbone of support among the upper orders during the Cinnanum tempus. ${ }^{50}$ Many must have still loathed Cinna for his actions in late 87 . But he had done enough to secure the support of some prominent groups. Such groups apparently tolerated the striking irregularities that mark this period.

\footnotetext{
${ }^{45}$ Taylor 1960, 105-6; Bispham 2007, 198 n. 185; De Ligt 2012, 115-16. Cf. the neutral perspective of SherwinWhite 1973, 155.

${ }^{46}$ App. B Civ. 1.76. Cf. Harris 1971, 254.

${ }^{47}$ Cf. Kendall 2008, 468-9, with some perceptive hypotheses on Cinna's rhetoric of influence over the Italians. I find no evidence that Cinna had to choose between placating the Senate and the Italians (as claimed by Badian 1958a, 242; Keaveney 1987, 183-5; 2005, 101). He could scarcely afford to eschew either source of gratia.

${ }^{48}$ Lovano 2002, 59-60, is especially instructive. Cf. Asc. 89C: equester ordo pro Cinnanis partibus contra Sullam steterat ('the equestrian order had stood on behalf of the Cinnan coalition against Sulla'). A statement of exaggeration surely (cf. Lewis 2006, 298), but with foundations in truth. On Marius' equestrian following, see Sall. Iug. 65.4-5.

${ }^{49}$ Cic. Verr. 2.1.35, with Brunt 1988, 460-1; Wiseman 1971, 6. Cf. Brut. 227; Rosc. 140; Phil. 8.7.

${ }^{50}$ Exact totals differ: App. B Civ. 1.95 (1,600 equites); 1.103 (2,600 equites); Val. Max. 9.2.1 (4,700 men in total); Flor. 2.9.25 (2,000 equites and senators). Cf. Bennett 1923, 35 n. 53. See Shatzman 1975, 204-5, on Cinna's support among the (both senatorial and equestrian) elite.
} 
How would support manifest itself in an age of defective elections? The census would not be completed in time to provide Cinna with much - if any - quantitative support from the new citizens. The votes of the equites, conversely, could command a huge amount of sway. But mere voter numbers meant little in comitia in 86 and 85, since the candidates were likely pre-selected by Cinna. Of critical importance was the support, or at least toleration, from those of substantial influence. More so than ever, suffragandus was subsidiary to gratia. ${ }^{51}$ Cicero hints at the proselytizing tactics of Cinna, claiming that he would never join such a cause ne si summa quidem eorum in me merita constarent ('even if the highest rewards conferred by them to me were fitting'). ${ }^{52}$ And Cinna had already astutely cultivated the gratia of a handful of prominent senators, forging a network of amicitia. ${ }^{53}$ With support from (many of) the equites, no doubt he was an unstoppable political force. Given how many aristocrats were absent from the city, it should come as no surprise that Cinna was met with little resistance. In addition, as with the irregular elections of Marius in the second century, the presiding magistrate found himself in a position of untrammelled influence: despite the stigma of presiding over one's own election, there was no substantive barrier to prevent re-election. Cinna would accept his own professio and those of his amici; the Senate was powerless to stop him. So, in short, Cinna, though doubtless in need of some votes to underscore his uncompetitive elections, relied far more on public support to legitimize his re-election, humiliate potential opponents, and reinforce the notion that any opposition was futile. ${ }^{54}$

Evanescent toleration of Cinna's consulships, particularly by the Senate, does not presuppose profound approval. We know from Sulla's march on Rome that carrying out such violence on the city could provoke significant hatred. Cinna's continuatio curtailed senatorial influence and political competition; it shut off all hopes of reaching the summa laus. Remove

\footnotetext{
${ }^{51}$ See Brunt 1988, 389-90, on gratia. Cf. Sall. Iug. 31.15 with Syme 1939, 157, on amicitia and politics. But see Brunt 1988, 351-61, with modifications of Syme's view. Cf. Q. Cic. Comm. Pet. 18, 29-31, on the importance of this influence in electoral canvassing. If Cinna and other successful candidates did canvass for their offices, it would have been designed to consolidate their influence over the People, and to perpetuate the impression that competitive comitia were taking place as normal. Cultivating popular support in this manner persisted even in the last months of the republic (Cic. Fam. 10.25.1-2) and in the empire (Suet. Aug. 56.1).

${ }^{52}$ Cic. Fam. 1.9.11. The letter as a whole is concerned with the balance between personal gratia (or merita, beneficia) and pietas (1.9.1), later contrasting the improbitas of Cinna with the virtus of Pompey (1.9.11), thus justifying Cicero's association with Pompey's amicus Caesar (1.9.12), as Cicero now owed him gratia together with Pompey. Cf. Balsdon 1960, 50, on gratia, and Hellegouarc'h 1972, 169-70, on meritum.

${ }^{53}$ Cf. Gruen 1968, 246, and Sartori 1971, 152, for a brief appraisal of the political value of Cinna's 'contatti personali'.

${ }^{54}$ In more competitive times, candidates relied on the public support of the lower classes even if their votes were worth very little in the comitia centuriata (so Tatum 2003/04, 208). The Cinnan comitia reduced Romans of all classes to this level. As Steel 2013, 124, puts it, 'without the circulation of the highest offices, there was no recognisable Roman elite.' Cf. Cic. Rosc. 136: qui non videret humilitatem cum dignitate de amplitudine contendere ('who could not see that men of low birth were competing with those with dignitas for prestige?').
} 
this essential part of the Roman political system, and mos maiorum is completely overturned. The murder of many of its key members had brought the Senate into line, but we can easily imagine its members seething with discontent. ${ }^{55}$ Many of Rome's aristocrats 'conformed but [were] not converted'. ${ }^{56}$

The elections for 85 clearly show just how much influence Cinna would continue to wield in Rome throughout 86. At the time of election, Sulla had not yet made peace with Mithridates, so there was no pressing fear of war in Italy (though it is entirely possible that Cinna may have cited this specious threat to justify his re-election). A loyal friend, one of the masterminds behind the siege of Rome, Cn. Papirius Carbo, was elected as his colleague. That Cinna desired and arranged for his candidature is certain. He had been among Cinna's most prominent friends

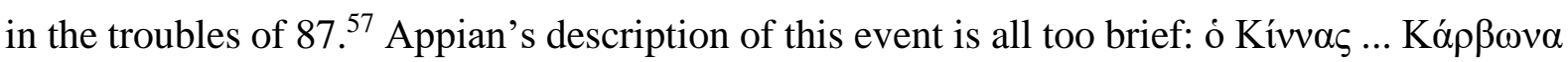

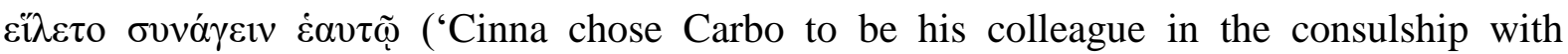
himself') ${ }^{58}$ Determining whether comitia were held on this flimsy evidence is, as ever, a vexed question. The expression in Livy's Periochae offers no concrete solution: L. Cinna et Cn. Papirius Carbo a se ipsis consules per biennium creati ('Cinna and Carbo, having made themselves consuls for two years...'). ${ }^{59}$ This is probably shorthand to the effect that Cinna presided over the comitia, nominating and announcing himself consul as well as his chosen colleague. ${ }^{60}$

This, in itself, was enough for later writers to deem these years a dominatio, a regnum. Let us now take a minor digression to interpret the vocabulary employed by contemporary and later writers to generalize the political system operative between 86 and 84. Dominatio is pejorative, instructive of the attitudes of later generations. ${ }^{61}$ It is demonstrably not a technical term to connote a coherent system of government: Tacitus describes both the dictatorship of

\footnotetext{
${ }^{55}$ Cf. Brunt 1988, 462, contra Bulst 1964, 324.

${ }^{56}$ Bennett 1923, 66.

${ }^{57}$ App. B Civ. 1.67.

${ }^{58}$ App. B Civ. 1.76.

${ }^{59}$ Liv. Per. 83 . Note the technical verb creo, which generally refers to election by popular assembly.

${ }^{60}$ So Lanzani 1915, 204 n. 1: the broad idea that our sources are putting across is 'l'autorità di Cinna sulle assemblee del popolo.'

${ }^{61}$ This became the usual expression to describe this period: Cic. Att. 8.3.6; Asc. 23C; Val. Max. 6.9.6. Cf. Phil. 1.34; Vell. Pat. 2.23.3.
} 
Sulla and the consulships of Cinna thus. ${ }^{62}$ It signifies excessive power held by a single individual, for which Romans had a low threshold. ${ }^{63}$ Likewise regnum, literally 'monarchy', is here metaphorical, as it tends to be in late republican discourse. ${ }^{64}$ There is little reason to doubt Cicero's statement that the Romans remembered Cinnam nimis potentem ('Cinna's excessive power'). ${ }^{65} \mathrm{He}$ was later censured as a tyrannus. ${ }^{66}$ But this power did not extend to annulment of the comitia. The parallels that Cicero makes between the Cinnae dominatio and the Caesaris regnum are instructive. Cicero's anticipation of Caesar's imminent march on Rome betrays fears of a repeat of the political situation experienced under Cinna. ${ }^{67}$

Cicero never once explicitly mentions a complete breakdown of constitutional politics during the Cinnae dominatio. It was indeed a time when sine iure fuit et sine ulla dignitate res publica ('the republic was without law and without any dignity'). ${ }^{68}$ Let us unpack the two prepositional phrases. The former (sine iure) is very broad: it can signify illegality as much as unconventionality. Ius is both custom and law. The expression could simply refer to Cinna's unconventional continuatio. Cinna and his friends were clearly in charge of the organs of the state, even if they felt the need to adhere to some constitutional scruples. One could easily see how this time would be, in Cicero's view, sine iure. It is worthy of note that he earlier employed the selfsame expression when describing the perturbations in Rome in April 49. ${ }^{69}$ Cinna may have acted iure in his march on the city, having been wrongly exiled..$^{70}$ But the manner of his rule was sine iure.

Sine dignitate is even more tantalizing. Dignitas is a quality more frequently ascribed to an individual, but, here, it is the republic as a whole that lacked any dignity. ${ }^{71}$ It echoes Cicero's sentiments on Caesar's civil war, where he famously described the dignitas rei p. as

\footnotetext{
${ }^{62}$ Tac. Ann. 1.1. Likewise Augustus' emperorship: 1.3. Cicero also describes Sulla's dictatorship (Phil. 2.108) and Tiberius Gracchus' tribunates (Brut. 212) in these terms. Cf. Urso 2016, 22-4, on the grammar of Sulla's dictatorship.

${ }^{63}$ See, e.g., Cic. Phil. 8.12 on the alleged dominatio Antoni during the crisis of early 43. Cf. Rep. 1.43 on the limitations of autocracy and democracy, and 1.53 on why it is better that the People ab optimis reguntur ('are ruled by the best men').

${ }^{64}$ See, e.g., Sall. Cat. 47.2; Cic. Cat. 3.9; Cic. Phil. 5.17; Har. 54. For general definitions of regnum, see Allen 1953, 232-4; Syme 1939, 152-5; Hellegouarc'h 1972, 560-5. Note that Cinna's and Sulla's periods of political domination (regna) are frequently treated in synonymous terms by later sources.

${ }^{65}$ Cic. Phil. 2.108. Cf. Quinct. 69: those in positions of influence in 83 poterant per vim et scelus plurimum ('had power through violence and excessive injustice').

${ }^{66}$ Sall. Hist. fr. 56.

${ }^{67}$ On this, see Mitchell 1979, 82-4.

${ }^{68}$ Cic. Brut. 227.

${ }^{69}$ Cic. Att. 4.1.2. Cf. Fam. 1.7.10.

${ }^{70}$ Cic. Att. 9.10.3, referring also to Sulla's first march on Rome.

${ }^{71}$ Dignitas, usually personalized in Cicero's Brutus, often describes the inherent ideal qualities of the consular office, particularly with regard to oratory in this work. See Brut. 165-6. Cf. 235, 239.
} 
amissa ${ }^{72}$ But the res publica itself was not amissa. Cicero says so himself: non illi nullam esse rem publicam sed in ea quae esset se esse principes neque hanc urbem conflagrare sed se in hac urbe florere voluerunt ('these men [Cinna, Sulla, Lepidus] did not wish there to be no republic, but to be themselves the principes in what remained; nor did they wish to burn the city to the ground, but rather themselves to flourish in this city'). ${ }^{73}$ What were lacking, then, were the critical elements of the republican system for the aristocracy: competition and opportunity. Dignitas here is neither 'ambiguous' nor 'purely subjective'. ${ }^{74}$ Nepos, for example, tells us of Atticus that, in his youth, owing to the political division (partes) in the 80s, neque sibi dari facultatem pro dignitate vivendi ('no opportunity was given to him for living in a way worthy of his dignitas'). ${ }^{75}$ Cicero makes explicit this connection between dignitas and gradus in an early speech: Sulla's return would restore domi dignitas et foris auctoritas ('dignitas at home and auctoritas abroad') and usher in honorem et gradum redditum ('the restoration of honos and political rank'). ${ }^{76}$ The best men were unable to make traditional political pursuits deserving of their dignitas. ${ }^{77} \mathrm{~A}$ republic without dignity was one where political opportunity and competition were blunted, where unworthy men held the reins of power. ${ }^{78}$ Cinna, a man of nimis potens, was assigning these magistracies. In 85 , his friend Carbo was the direct beneficiary.

Just as Caesar would later hold snap comitia in 49, so Cinna did not cancel this republican mainstay. Roman elections did not depend on the notion of competition. As such, if Cicero was able to use the Cinnae dominatio as a credible exemplum, it must follow that such broad principles of the republic were still followed. There were indeed intolerable disfigurements of republicanism' ushered in by Cinna and Caesar, ${ }^{79}$ but in neither case did this extend to the complete and utter subversion and cancellation of the comitia. Further, as argued in Chapter Two, Cinna had no practical reason for cancelling the comitia altogether. Comitia strengthened Cinna's position, whereas a complete disregard of the maiestas populi would

\footnotetext{
${ }^{72}$ Cic. Fam. 6.21.1.

${ }^{73}$ Cic. Cat. 3.25. Cf. Val. Max. 7.6.4 for similar sentiments on the war between Carbo and Sulla.

74 Gruen 1968, 240; Salmon 1964, 66.

75 Nep. Att. 2.2. Cf. Millar 1988, 41-2, on Atticus' dignitas.

${ }^{76}$ Cic. Rosc. 136. For this explicit connection between gradus/honor and dignitas, see, e.g., Isid. Etym. 2.21.4; Cic. Off. 2.65 with Balsdon 1960, 46. Cf. Hellegouarc'h 1972, 400-6.

${ }^{77}$ Asc. 23C calls the victims of the Marian massacre the optimates, while Cic. Rosc. 136-8 limns the Sullan cause as that of the optimates.

78 Thus Douglas 1966, 168, is surely right in saying that, in Brut. 227, Cicero 'has in mind the control of elections and other unconstitutional proceedings'.

${ }^{79}$ Mitchell 1979, 84.
} 
significantly weaken his claim to legitimacy. This maiestas was curtailed, but not ignored entirely.

The quaestiones, too, functioned, albeit to a much lesser degree than usual. Cicero recalls that this was a bad time for oratory: only by there being in foro solitudo could Antistius - vitio vocis and all - succeed as an orator. ${ }^{80}$ With few capable men around, there was minimal competition in the quaestiones. The city was emptied of its most able politicians and jurists owing to oratorum aut interitu aut discessu aut fuga ('either the death, departure, or exile of orators'). ${ }^{81}$ We know of just one trial: that of Pompey, the future Magnus, in 86 . He was acquitted from the charge of peculatus, with the support of the future consul Carbo, Philippus the censor, and Hortensius the orator. ${ }^{82}$ It seems almost inconceivable that he would have escaped prosecution had Cinna borne him a grudge for his father's crimes. ${ }^{83}$ This seems to be another example of Cinna's attempts to cultivate certain powerful or, in this case, dangerous members of the aristocracy. Pompey owed Cinna gratia, and would later serve in his army. ${ }^{84}$ It may be assumed that some other trials were held in this period, but they were certainly scaled back. Should Cinna have an interest in the outcome, the ruling was likely to fall in his favour.

Events within Rome are obscure to us for almost all of 85. M. Marius Gratidianus ( $p r$. 85,82 ), one of the tribunes loyal to Cinna in the conflagrations of 87 , was elected praetor for the year, passing a coinage reform that made him extremely popular. ${ }^{85}$ Another loyal friend, Q. Sertorius, was likely his colleague in the praetorship. ${ }^{86} \mathrm{M}$. Fannius and L. Critonius, likely the plebeian aediles of this year, minted coins featuring Ceres wearing a wreath of corn, and distributed them through Italy. ${ }^{87}$ There were very real attempts to convey a sense of stability

\footnotetext{
${ }^{80}$ Cic. Brut. 227.

${ }^{81}$ Cic. Brut. 308. Cf. Rosc. 11, 28.

${ }^{82}$ Val. Max. 5.3.5; 6.2.8; Plut. Pomp. 2.2; Cic. Brut. 230.

${ }^{83}$ Gruen 1968, 244-6 (with some revisions by Hillman 1998, 176-93), must remain the standard interpretation of this quaestio. Cf. the similar arguments from Bennett 1923, 42-3; Keaveney 1982b, 113-14; Seager $2008,25$. The position of Lovano 2002, 66, that Cinna desired Pompey's death and was scuppered by these three leading men, is distinctly unlikely. Cinna did not have to 'trust' Pompey to desire his acquittal. It is very hard to believe that this coalition of leading men (including Cinna's amicus Carbo) would unite against the consul thus. Moreover, Plutarch's story that Cinna ordered Pompey's assassination in 87 (Pomp. 3.1) is likely a product of the author's eulogizing of Pompey in contradistinction with his cruel father and Cinna (so Hillman 1996, 82-3, contra Keaveney 1982b, 112-13).

${ }^{84}$ Plut. Pomp. 5.1. Seager 2008, 25-6, is surely right to dismiss the rumours that Pompey was somehow involved in Cinna's death in 84.

${ }^{85}$ See Sumner 1973, 118-19, on the dating of Gratidianus' praetorships. Cf. Val. Max. 9.2.1; Cic. Off. 3.80-1; Asc. 84C; Plin. HN 33.132, 34.27.

${ }^{86}$ Konrad 1994, 74-6.

${ }^{87}$ CRR 717. Cf. Rowland 1966, 412.
} 
and economic recovery in these years. Indeed, there seems to have been a brief economic revival during this time. ${ }^{88}$ Otherwise, our sources are silent on domestic affairs in early 85.

It was not until late 85 that cracks started to appear in the regime, fuelled by Sulla's negotiations with the Senate. Sulla made peace with Mithridates in the autumn of 85, and promptly sent an intimidating letter to the Senate, maintaining his status as the legitimate proconsul. His letters to the Senate were an example of political genius on Sulla's part, igniting a division between the Senate and the consuls that, until this moment, had been successfully repressed. ${ }^{89}$ The consuls, who had seemingly spent the entirety of their consular year at Rome, immediately sent envoys to petition for troops from their Italian friends. With war on the cards, the consuls now had a much more tangible reason for justifying their re-elections. Sulla had explicitly promised to punish his enemies who had declared him hostis. ${ }^{90}$ Already in autumn 85 , the consuls knew the stakes.

It is in this context that we need to understand the comitia for 84 . These elections were held earlier than usual, but we have the direct testimony from Appian that comitia were indeed

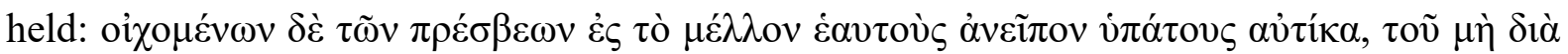

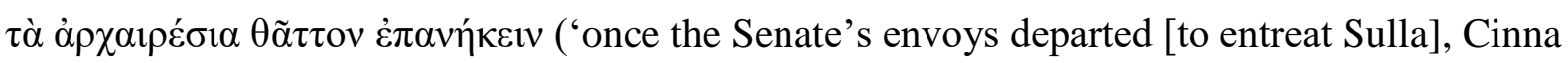
and Carbo immediately announced themselves consuls for the next year, so as not to have to return hastily for elections'). ${ }^{91}$ This passage indicates that the consuls were within Rome when their election was announced: they held a snap election so that they need not return ( $\dot{\varepsilon} \pi \alpha v \eta \dot{\kappa \varepsilon} v)$ to the city while absent recruiting men. ${ }^{92}$ Appian's expression that Cinna and Carbo announced

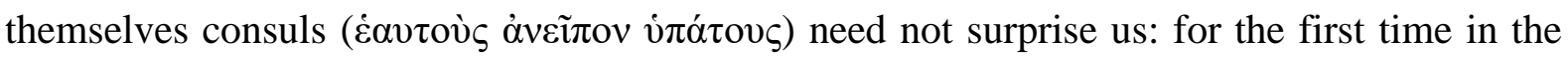
republic, both consuls were re-elected for the following year, with Cinna again presiding over the procedure.

\footnotetext{
${ }^{88}$ Crawford 1964, 148. Barlow 1980, 211-12 et passim, however, points out the economic weakness of the government that would be exposed when war returned to Italy. Cf. Lovano 2002, 70-6, with an extensive discussion of economic measures in the mid-80s.

${ }^{89}$ App. B Civ. 1.76-7. On the nature of the negotiations, see Keaveney 2005, 98-9. Cf. Lovano 2002, 107: his letter 'succeeded in driving a wedge between the Cinnans and their luke-warm supporters in Rome and across Italy.'

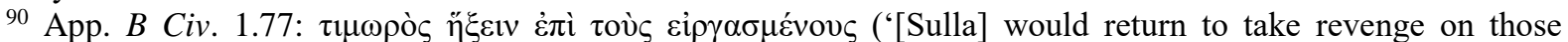
responsible'). Sulla's later promises for clemency (1.79) were likely, justifiably, disbelieved by the consuls.

${ }_{91}^{91}$ App. B Civ. 1.77.

${ }^{92}$ Bennett's reading of Appian (1923, 59-60) is surely correct: Appian does not mention either consul having left Rome in 85, leaving Rome only once they had proclaimed themselves consuls (contra Levi 1928, 192-3; Frier 1971, 592). On the basis of Liv. Per. 80, Gabba 1967, 208, argues that Cinna and Carbo were per biennium creati in late 86, so only one election was held. Given that Appian was clearly aware of two separate comitia, we can explain the Livian phrase as careless epitomizing.
} 
But his wording is curious for other reasons. Even if they did hold the comitia slightly earlier than usual (late autumn or early winter 85), ${ }^{93}$ the consuls would have still needed to rush back to Rome on 1 January for the traditional religious and legal swearing in. How, then, would holding the election at an earlier date make their recruitment more efficient? There are two possibilities. First, they may have followed the dubious example of C. Flaminius and failed to perform these crucial ceremonies, beginning their consular year outside Rome. ${ }^{94}$ This was hardly an auspicious precedent to follow, so we should perhaps search for an alternative

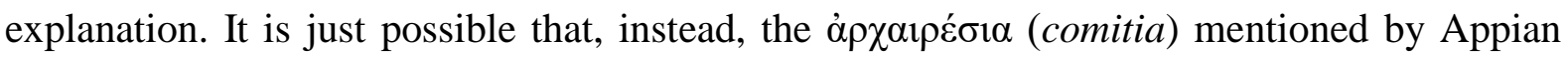
includes not just the election, but conflates the prorogation of the consuls' imperium for $84 .{ }^{95}$ That is, Carbo and Cinna were sworn in as consuls under the provisions of the lex Curiata before the end of 85 . Under normal circumstances, this would seem absurd: the consuls' term always lasted a year. But these were exceptional times. The consuls needed an immediate and legitimate way to maintain their imperium without wasting time, and without bypassing the critical legal and religious mores that traditionally took place on 1 January. ${ }^{96}$ It is possible that the consular year of 85 was cut slightly short to accommodate the speedy transition in office between 85 and 84 . But, given the parlous nature of our sources, we cannot entertain either hypothesis with any degree of certainty.

Stories of the consuls' panic may well be exaggerated..$^{97}$ This was a war in which the consuls had very good reason to have confidence: the massed ranks of Italy could far outnumber those which Sulla had to offer. As Peter Brunt puts it, 'there could have been no rational expectation that with a mere five legions [Sulla] could overcome the forces which could be mobilized against him throughout Italy. ${ }^{98}$ Still, Sulla had played the political game immaculately in the east, having secured Mithridates' surrender despite Fimbria's attempts to the same effect: Mithridates clearly viewed Sulla as Rome's legitimate proconsul. ${ }^{99} \mathrm{He}$ subsequently won over Fimbria's legions, forcing the latter to commit suicide. ${ }^{100}$ Taking time to organize affairs in the east, Sulla unhurriedly began to prepare for his return to Italy.

\footnotetext{
${ }^{93}$ Gabba 1967, 204-5, suggests that the news of Mithridates' capitulation would have reached Rome in around October.

${ }^{94}$ Liv. 21.63; 22.5-6; Cf. Linderski 1986, 2204, for general details on the iura of Roman augural laws.

${ }^{95}$ It bears noting that Appian may have been unaware of the lapse between election and taking office, which may

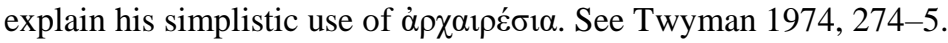

${ }^{96}$ See Pina Polo 2011, 19-20, for an overview of the rites and lex Curiata upon assumption of office. Cf. Cic. Vat. 23 on Cinna's alleged attentiveness to religious scruple.

${ }^{97}$ See, e.g., App. B Civ. 1.76; Plut. Mar. 45.2-3. Keaveney 1982b, 114, deploys the latter example to postulate Cinna's terror.

${ }^{98}$ Brunt 1988, 462.

${ }^{99}$ Cf. Bulst 1964, 321, on how Sulla 'outmanoeuvred' Fimbria.

${ }^{100}$ App. Mith. 59-60; Plut. Sull. 25.1.
} 
Attributing blame for the trigger of the civil war of $83 / 2$ is not germane to my purpose, but one can easily understand why neither party would be willing to compromise. ${ }^{101}$ The dignitas of both depended on the other's annihilation. Cinna and Carbo had been directly threatened by the hostis, while Sulla, the (self-proclaimed) legitimate proconsul and conqueror of the Asia, deserved gloria worthy of his dignitas. The Senate futilely attempted to find a compromise, ineffectually ordering the consuls to cease recruiting. ${ }^{102}$ For the first time under the Cinnae dominatio, the Senate's voice was heard, with its princeps Flaccus speaking on behalf of peace in the Senate. ${ }^{103}$ However, the voices of the compromisers were drowned out by two men confident that they had enough resources to defeat the other.

But Cinna died in early 84 . He was killed by a mutiny of his soldiers as he was preparing to head for Liburnia in the Balkans, presumably to weaken Sulla's position, if not to meet him in battle immediately. ${ }^{104}$ After all, his amicus L. Cornelius Scipio Asiagenes was governor of Macedonia with two legions at his disposal. ${ }^{105}$ Together they could shut off Sulla's routes back to Italy. ${ }^{106}$ As it happened, none of this would eventuate. Cinna's death at Ancona, completely unconnected with the political situation, may be explained away as simply bad fortune: a disastrous winter storm had created an atmosphere of insubordination that culminated in rebellion. ${ }^{107}$ His haste in crossing the Adriatic before sailing season may have backfired. ${ }^{108}$ Appian may also be correct in inferring that the troops (or at least this mustering thereof) were unwilling to engage in another civil war. It was all very well calling on the loyalty and gratitude

\footnotetext{
${ }^{101}$ Keaveney 2005, 103, makes this observation, though perhaps unfairly traces the escalation of tensions to the 'intransigence of the Cinnans'.

102 App. B Civ. 1.77 .

103 Liv. Per. 83.

104 Petković 2008, 123-5, argues that Cinna's move was primarily defensive, designed to prevent Sulla, who had made ventures into the Balkans in 85 (Gran. Lic. 27C; Liv. Per. 83; App. Mith. 55; Plut. Sull. 23.5; Eutr. 5.7.1) from attacking northern Italy. Badian's unattested suggestion that Cinna was moving to Liburnia merely to train his troops $(1962$ b, 58$)$ has been comprehensively refuted by Balsdon 1965, 232; Lovano 2002, 108-9. Liburnia provided a safe point of entry to the embattled east (Dzino 2010, 73-4), and there is no reason to doubt the explicit

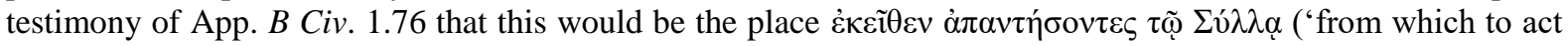
against Sulla').

105 App. Ill. 5. Cf. Badian 1958b, 6-7.

${ }^{106}$ It is also likely that Cinna was unaware of Fimbria's recent death, and so optimistically thought that the respective commanders in Liburnia, Macedonia, and Asia, could squeeze Sulla into surrendering (cf. Lanzani 1915, 216). As it happened, Fimbria had died in late winter 85/4 (Lintott 1976, 491). The erroneous placement of Fimbria's death after Cinna's in Liv. Per. 83 may stem in part from the poor communication channels across the Mediterranean. Sulla, after all, apparently did not know about Cinna's death until almost a year later upon his arrival in Italy in early 83 (App. B Civ. 1.79).

${ }^{107}$ See De vir. ill. 69 for the location. App. B Civ. 1.78 is preferable to Plut. Pomp. 5.1-2: the latter eulogizes Pompey and magnifies his role in the murder of Cinna, retrospectively deemed iure. The rational explanation of the latter is that Pompey fled the camp because he, too, feared for his life. Cf. Seager 2008, 26. Contra Keaveney 1982b, 116-17.

108 App. B Civ. 1.78 informs us that one lot of troops had crossed successfully. The next sailing coincided with a storm, compelling the soldiers to desert. Cf. Lovano 2002, 109.
} 
of the Italian leaders, but sailing over to the Balkans for a long campaign, possibly to culminate in open conflict with fellow Italians, may have been a hard sell for many in the newly formed army. Still, his death defies systemic or political explanation. ${ }^{109}$

Cinna's death changed everything. It is no coincidence that the real problems only start to arise immediately afterwards. ${ }^{110}$ The Senate had already attempted, and failed, to exercise its auctoritas to sue both parties for peace, manifesting a degree of independence under Cinna's regime. But it bears remembering that much of Cinna's strength relied on personal loyalty, on gratia. With his death, many members of the aristocracy were far less apt to prop up the regime. Both sides had already started a propaganda campaign of sorts. Sulla had made vague overtures to the Italians, promising not to punish the newly enfranchised citizens. ${ }^{111}$ Coins had been issued by Cinna's associates cementing their position as the legitimate and powerful government. ${ }^{112}$ But the propaganda campaign would not gain momentum until after Cinna's death. Sulla would only start commissioning coins with obvious propagandist motives from 84 at the earliest. ${ }^{113}$ This cold war would soon become very hot indeed.

The Senate, emboldened by Cinna's death, now saw an opportunity to make real changes to the political scene. Tribunes, clearly not entirely in the thrall of the consuls, commanded that Carbo should return to Rome to hold elections for a suffect consul, however

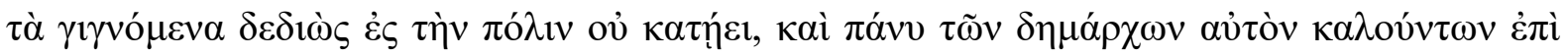

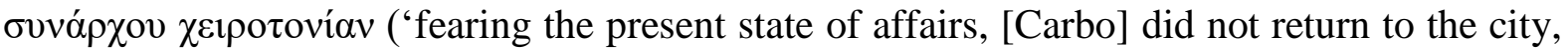
despite the urgent call of the tribunes to elect a colleague in the consulship'). ${ }^{114}$ The attention that Appian gives to the tribunes' (and, by extension, the Senate's) insistence on the abortive comitia of 84 is once more suggestive that the process had not been interrupted while Cinna was alive. The presence of (some) tribunes hostile to Carbo seems to illustrate that the consuls'

\footnotetext{
${ }^{109}$ Keaveney 1987, 185, draws a direct link between Cinna's murder and his (alleged) broken 'promise to redistribute'. The issue of suffragium, however, seems not to have been a factor in his death at all.

${ }^{110}$ App. B Civ. 1.79 draws this direct link: when Sulla arrived in Italy in early 83, Rome was in disorder ( $\tau \grave{v} v$

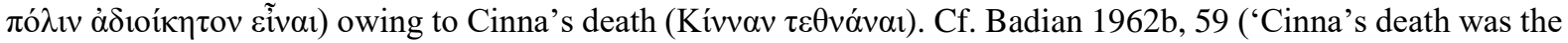
turning-point'); Katz 1972, 159 ('Cinna himself was the dominant figure in the government').

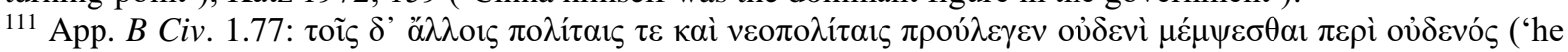
proclaimed that no one among rest of the citizenry, nor the new citizens, would be blamed'). There seems little reason to doubt this detail in Appian's narrative (Salmon 1964, 67; Frier 1971, 591; contra Badian 1962b, 57-8), though it is worth noting that the issue of enfranchisement is not raised here (cf. Bispham 2007, 193-4). Keaveney 1987, 186, perhaps overstates the effectiveness of Sulla's letter in precipitating 'Italian reluctance to fight'.

${ }^{112}$ Coinage catalogued in CRR 705-35. See Rowland 1966; Luce 1968, 37-8, who notes the increase in military imagery from 85/4. Cf. Alföldi 1976, 115-19: the high quantity of coins depicting naval scenes dating around 86 may suggest a propagandistic attempt to show off Rome's military might by the aedile (?) L. Rubrius Dossenus. ${ }^{113}$ Ramage 1991, 102-6.

${ }^{114}$ App. B Civ. 1.78 .
} 
influence over elected officials may have been slipping in 84 (at least after Cinna's death). ${ }^{115}$ The Senate likely had a candidate (or candidates) in mind, first to break the nepotistic domination of those favoured by the consuls, but also, more pressingly, to assign a consul who held peace as a priority. The Senate's renewed confidence, stemming directly from Cinna's death, is manifested by their threats to abrogate Carbo's imperium should he not return immediately. ${ }^{116}$ Carbo backed down, but, fearing the election of an inimical colleague, successfully manufactured a delay in proceedings. Lightning then conveniently delayed the comitia again until summer, by which point Carbo could scramble to recover from the blow of Cinna's death, and continue to raise troops in the north. The election was never held. Religionspolitik is demonstrably at play: one suspects that Carbo benefited from friendly augurs. He could still rely on the backing of many public officials. In this way, he managed to remain in the consulship alone for the remainder of $84 .{ }^{117}$

Let us, then, reflect on the magisterial elections, or appointments, while Cinna was consul. We know of few specific magistrates, though many names of Cinna's partisans have been preserved by the sources. ${ }^{118}$ Badian has alleged that there is no decisive evidence to suggest that Cinna had attempted to 'pack' the lower magistracies. ${ }^{119}$ It would have been unfeasible to fill each of the public offices with loyal men. The tribunes' insubordination in 84 immediately following Cinna's death is proof of this. However, magistrates were not necessarily selected on the basis of past loyalty, but instead as a guarantee of future obedience. If Cinna earmarked a young aristocrat for, say, the quaestorship, it would be expected that he would repay this debt of gratia with loyalty. Think, for instance, of Verres' quaestorship in 84, during which he served under Carbo in northern Italy. Cicero roundly criticizes Verres' subsequent relictionem proditionemque ('abandonment and betrayal') of his consul, a move which Verres (in Cicero's invective) hoped would be gratam (quite explicitly painting Verres as ingratus). ${ }^{120}$ Few would have followed Verres' example until the tide turned in Sulla's

\footnotetext{
115 There is, however, no good reason to assume, as Badian 1962b, $58 \mathrm{n}$. 12, does, that 'the tribunes' action against Carbo must have been unanimous'.

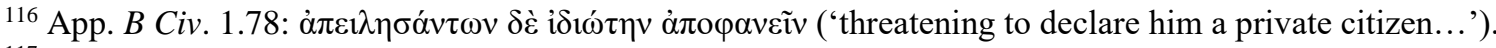

117 Vell. Pat. 2.24.5; Plut. Pomp. 5.2.

118 Shatzman 1975, 204 n. 118, catalogues some of the named individuals associated with Cinna. Some additional elections of Cinna's adherents may be tentatively listed. L. Cornelius Scipio Asiagenes (cos. 83) would assume a propraetorship in Macedonia in 85, so it is distinctly likely that Cinna secured his praetorship for him in 86 (Badian 1958b, 6); C. Flavius Fimbria was likely awarded the quaestorship for 86 (Lintott 1976, 489-90); C. Marcius Censorinus, executor of Octavius, may have also received this honour in the same year (Reams 1993, 283) and was of praetorian status by 82 (App. B Civ. 1.93).

${ }^{119}$ Badian 1962b, 58.

${ }^{120}$ Cic. Verr. 2.1.35. According to this Ciceronian adumbration of Roman mores, gratia was critical even if the superior were reprehensible. Cf. Cic. Verr. 2.1.39.
} 
favour. To reiterate: the consuls' strength rested on personal loyalty. That tribunes began to serve that Senate, and that the Senate started to wield more influence immediately following Cinna's death, cannot have been a coincidence.

Carbo was very active in his sole consulship. After the abortive comitia early in the year, he returned to his province of Cisalpine Gaul to continue to rally support. ${ }^{121} \mathrm{He}$ allegedly requested, and was denied, permission from the Senate to gather obsides ('hostages') from the Italians in order to secure their loyalty. ${ }^{122}$ It was common practice for the Romans to demand hostages to secure the cooperation and goodwill of their socii and amici in warfare. ${ }^{123}$ But it is curious that Carbo should need such a drastic measure to secure loyalty from Rome's new citizens. This Livian report has been deployed variously to demonstrate the reluctance of the Italians to fight, ${ }^{124}$ the tactical weakness of Cinna's position, ${ }^{125}$ and the (alleged) failure of Cinna's attempts of full enfranchisement of some Italian communities. ${ }^{126}$ Each of these factors may be partially at play in some areas across Italy. Indeed, we are told that a magistrate in the northern city of Placentia, M. Castricius, refused Carbo's attempts at rounding up hostages, suggesting that Carbo did not heed the Senate's refusal. ${ }^{127}$

But this passage is not definitive proof of a wholesale refusal to collaborate with the sole consul. ${ }^{128}$ Instead, we may take this attempt from Carbo as proof of his desperation to raise as big an army as possible, and of the divisions inherent in any society on the brink of civil war. As Appian tells us, the people of Rome sided with the consul(s), albeit reluctantly ( $\mu \varepsilon \tau \grave{\alpha}$

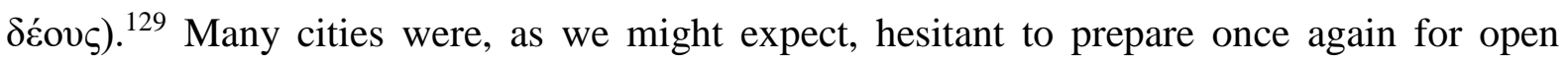
conflict. Many did join Carbo's cause: Gauls would appear in Carbo's army during the Civil War, and he had a large enough army to prolong the war until $82 .{ }^{130}$ Divided though Italy may

\footnotetext{
121 That he held this province as consul is confirmed by Cic. Verr. 2.1.34.

${ }^{122}$ Liv. Per. 84. It is striking that Carbo attempted to take hostages in Placentia (Val. Max. 6.2.10), a city just south of the Po that had been enfranchised by this point. See Taylor 1960, 124, 276; Sherwin-White 1973, 157.

${ }^{123}$ See, e.g., Liv. 10.11.13; 43.21.2-3.

${ }^{124}$ Frier 1971, 597-8; Keaveney 1984b, 115-16.

${ }^{125}$ Keaveney 1984b, 133.

${ }^{126}$ Keaveney 1982a, 508.

127 Val. Max. 6.2.10.

${ }^{128}$ Cf. Lovano 2002, 88, with similar arguments.

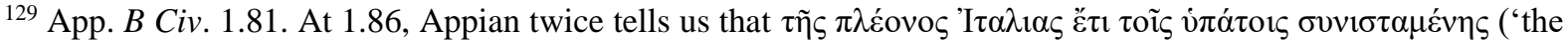
majority of Italy was still united with the consuls') in 83 .

${ }^{130}$ App. B Civ. 1.86, 1.91-2; Plut. Pomp. 7.1-3. Note that Cinna had also called on their services in late 87 (App. B Civ. 1.74).
} 
have been, there was enough unity to muster a very large army to face Sulla. ${ }^{131}$ The most we can say is that Carbo had mixed success, only for defections to increase as the war turned in Sulla's favour in 83. For example, Pompey, banking on his father's influence in Picenum, raised a private militia for Sulla's invasion. Plutarch reports that many deserted to Sulla's side, presupposing that many had previously been loyal to the consuls. ${ }^{132}$ If the war had turned against Sulla, we might easily envisage Pompey and the people of Picenum maintaining their

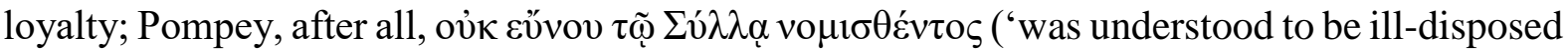
towards Sulla'). ${ }^{133}$ Nevertheless, despite some defections, ${ }^{134}$ the group of aristocrats who had done especially well under Cinna - those who we might consider to be part of his inner circle - remained united against Sulla, with large armies at their disposal. ${ }^{135}$

Carbo's peculiar petition, accepted by the Senate, to disband both his own and Sulla's army in 84 seems incongruous with this expeditious and concerted mustering. ${ }^{136}$ Clearly this senatus consultum was never, or scarcely, heeded, since our source swiftly moves on to treat of the military preparations of Carbo in late $84 .{ }^{137}$ That it was proposed by Carbo himself (per factionem Carbonis) is intriguing: it reveals something of Carbo's politicking during this period, as he attempted not to alienate the Senate entirely and paint Sulla as the aggressor. ${ }^{138}$ The emptiness of this gesture was soon revealed: Carbo spent much of the year ensuring the loyalty of the northern cities. Carbo's strange actions in his sole consulship, mustering troops while suggesting disbandment, provide the slightest of glimpses into the otherwise obscure political manoeuvres between Carbo and the Senate.

The final two elections before Sulla's successful return, those in late 84 and late 83 , follow Cinna's trend of political nepotism and absence of competition. It would be tempting to suggest that the dramatic break in continuatio in the consulship of 83, with C. Norbanus' and L. Cornelius Scipio Asiagenes' ascension to the consulship, represents a shift in attitude and a

\footnotetext{
${ }^{131}$ According to the calculation of Lovano 2002, 113-14, Sulla was outnumbered two to one. Cf. Brunt 1971a, 440-1, who estimates that roughly ten to twenty legions were raised in Italy by 84 .

132 Plut. Pomp. 6.1-4. The leaders of the town of Auximum, for instance, had sided with Carbo, as, one would expect, most had north of Rome.

${ }^{133}$ App. B Civ. 1.80. Cf. Caes. B Afr. 22.

${ }^{134}$ Listed in Keaveney 1984b, 142-3, mainly 'composed of young men of lower rank.'

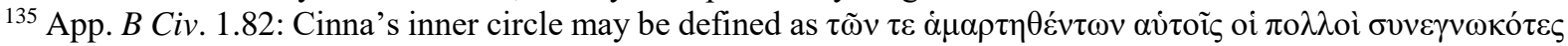
('the many, sharing in guilt with [the consuls]') - those discerning that, if Sulla won, their fate would be to endure

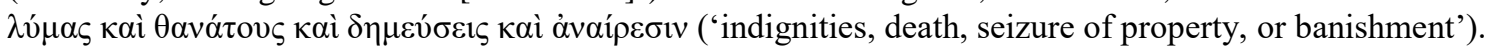

${ }^{136}$ Liv. Per. 84.

137 Liv. Per. 84: praeterea belli apparatum, quod contra Syllam excitabatur, continet ('it then details the preparations for the war which was being mongered against Sulla').

138 So Lovano 2002, 110.
} 
weakening of Carbo's position. ${ }^{139}$ It is, of course, possible that the latter was muscled out by the two new consuls: Carbo's influence may have been dependent on Cinna's. Appian, however, was under the impression that their aims were united. ${ }^{140}$ Both had demonstrated their loyalty to the consuls of 84 , not to mention their military aptitude. ${ }^{141}$ There are other strategic reasons why Carbo might need to eschew the consulship of 83. Having been the consular imperator of Cisalpine Gaul in 84, he already had command of northern troops. Presumably more needed to be mustered to anticipate the invasion from the south. ${ }^{142} \mathrm{He}$ was in the best position for this, having mustered troops in Picenum with Cinna, continuing after the latter's death. ${ }^{143}$ One might opine that, with his consular status, he was the only individual with enough clout to muster a sizeable army from the north.

His movements are hard to trace between Cinna's death and his return to the consulship in $82 .{ }^{144}$ He must have returned to Rome briefly in late 84 to preside over the election of Scipio and Norbanus, returning north soon after, invested with proconsular imperium for the province of Cisalpine Gaul, where he would continue to raise troops from his base in Ariminum. ${ }^{145}$ After Pompey rebelled, Carbo turned up further south in Picenum, presumably late in 83 , his legates having failed to quell the uprising; Carbo too was defeated. ${ }^{146}$ Next Carbo returned to Rome, compelling the Senate to declare all of Sulla's followers hostes. ${ }^{147}$ Now returned to Rome and privatus, Carbo presumably now made arrangements for his return to the consulship.

Sulla had landed in Brundisium in early 83. Despite the massive army at the consuls' disposal, Sulla, thanks to his military nous, good fortune, and superior propaganda, gradually

\footnotetext{
${ }^{139}$ Lovano 2002, 111, rightly objects to Badian's hypothesis $(1958,243-4)$ that the new consuls were 'chosen for advertisement'. Both had a sound military record, and their consulship would provide opportunity for three active commanders with imperium in central and northern Italy.

${ }^{140}$ App. B Civ. 1.82: they were united by a hatred ("̌ $\chi \theta \rho \alpha$ ó $\mu$ oí $\alpha$ ) of Sulla. That the new consuls had the $\pi \rho \sigma^{\sigma} \chi \eta \mu \alpha$ $\tau \tilde{\eta} \varsigma \pi \alpha \tau \rho i ́ \delta$ o $\varsigma$ ('pretext of the state') need only mean that the Senate was, at this stage, backing the consuls and Carbo to win the war (contra Steel 2013, 125).

${ }^{141}$ Scipio had fought with success in Macedonia (App. Ill. 5) and Norbanus in Sicily (Diod. Sic. 37.2.13; Cic. Verr. 2.5.8). See Konrad 1994, 78-9, and MRR 2.62, for prosopography. Norbanus was almost certainly a novus homo, though doubts remain over whether he was a new citizen too. See Brunt 1982, 9 n. 33, contra Gabba 1967, 218.

142 Cic. Verr. 2.1.34.

${ }^{143}$ Pompey had to strive to win over those previously loyal to Carbo in Picenum (Plut. Pomp. 6.4).

${ }^{144}$ Here I broadly follow the synthesis of Appian's and Plutarch's respective narratives provided by Gabba 1967, 226.

145 Cic. Verr. 2.1.34-40 never explicitly informs us that Carbo was proconsul there in 84, but continuity in command is certainly implied by Verres' defection to Sulla later in 83. (His scholiast more explicitly identifies Carbo's province as Gallia; Ps.-Asc. 208S, 333S.) MRR 2.64 and Badian 1966, 908, conflate Italy and Cisalpine Gaul as the same province. But see Rafferty 2017, 152-3, who argues that Carbo had Gaul alone, while the consuls managed Italy. He also observes that Ariminum was Carbo's logical base of operations. I am immensely grateful to Dr Rafferty for his counsel, and for allowing me to read his article in advance of publication.

146 Plut. Pomp. 7.3.

${ }^{147}$ App. B Civ. 1.86.
} 
won over Italy with a mixture of extraordinary brutality and ostentatious clementia. ${ }^{148}$ Sulla also made real attempts to win over some Italian communities. ${ }^{149}$ Defeats outnumbered victories for the consuls and Carbo in 83, and the consuls' armies deserted en masse. ${ }^{150}$ By the time the comitia for 82 came around, the last before Sulla's absolute victory, the tide had turned in his favour. Once more, these comitia were a farce, with Carbo and Marius' youthful son elected per vim. ${ }^{151}$ The wartime elections continued to produce partisans of those united against Sulla. ${ }^{152}$ There was some dissension within the ranks: Sertorius objected to Marius' election, perhaps with designs on the office himself. ${ }^{153}$ M. Marius Gratidianus, bizarrely, received a second praetorship despite his designs on the consulship. ${ }^{154}$ Nowhere is the manipulation of the comitia more clear than the elections for 82. Marius, a mere twenty-seven years old, rose to prominence thanks to his name. ${ }^{155}$ It is fair to assume that the beleaguered Scipio, having been deserted by his armies not once but twice during his consulship, limped back to Rome to preside over these elections. ${ }^{156}$ The two most powerful men in Rome were not to be denied: Gratidianus' praetorship was a 'consolation prize', ${ }^{157}$ and Sertorius received a propraetorian command in Spain, ensuring his expeditious departure. ${ }^{158}$ By this stage, the consuls were little more than warlords. But comitia were still seemingly held.

The Civil War continued throughout most of 82, costing thousands of lives, until Sulla finally triumphed, annihilating his enemies and assimilating the defectors. Much ink has been spilled about the Sullan dictatorship and proscriptions, which need not be repeated here. His reforms and his proscriptions are of interest to us for a couple of reasons. His ban on continuatio

\footnotetext{
${ }^{148}$ See App. B Civ. 1.86 on Sulla's mustering tactics in late 83. On propaganda, see Ramage 1991, esp. 102-6; Frier 1971, 585-604; Santangelo 2007, 67-77. Cf. Keaveney 1984b, 129, 135-6; Flower 2006, 88: Sulla's group of aristocratic exiles (Plut. Sull. 22.1) was a terrific propaganda coup, allowing him to claim legitimacy in a period when legitimate rule was under question.

${ }^{149}$ Liv. Per. 86; Vell. Pat. 2.25.1; with Santangelo 2007, 75-7. Keaveney 1982a, 507-10, perhaps puts undue emphasis on the issue of suffragium: survival seems to have been the central issue for the Italians with once civil war began.

${ }^{150}$ App. B Civ. $1.80-6$.

${ }^{151}$ Liv. Per. 86. His election was a brazen contravention of electoral mores: the Livian phrase likely refers to Marius' youthfulness and lack of other offices, and possibly to intimidation exercised to see off potential competition from the likes of Sertorius. Cf. Liv. Per. 69 for identical phrasing: per vim can connote physical violence or violation of constitutional principles.

${ }^{152}$ App. B Civ. 1.95; Plut. Sull. 27.3.

${ }^{153}$ Plut. Sert. 6.1. Exuperantius' (50Z) identification of Sertorius as aemulus ('rival') of the younger Marius seems to suggest that both sought the consulship of 82. Cf. Gabba 1967, 229; Konrad 1994, 77-8.

${ }^{154}$ Cic. Off. 3.81; Asc. 84C; Val. Max. 9.2.1. Cf. Sumner 1973, 118-19; Konrad 1996, 104.

${ }^{155}$ The age provided by App. B Civ. 1.87 and De vir. ill. 68 (27) is preferable to Liv. Per. 86 (20), as he had served with his father in the Social War. Cf. Badian 1958a, 244.

${ }^{156}$ App. B Civ. 1.85-6; Plut. Sert. 6.3; Pomp. 7.3. Both times Scipio successfully escaped or was released (cf. Cic. Phil. 12.27). He presumably did not flee to Massilia (Cic. Sest. 7) until around the time of the ultimate defeat in 82.

${ }^{157}$ So Sumner 1973, 119.

${ }^{158}$ Exup. 50Z; Plut. Sert. 6.1.
} 
(a reinstatement of an earlier law, with added prescriptions) was a clear move to ensure that there could be no repeat of the domination of magistracies by Cinna and his amici. ${ }^{159}$ In contradistinction with the Cinnae dominatio, Sulla's ensured that the republic was recuperata. ${ }^{160}$ The disputed (but undoubtedly multitudinous) number of people proscribed demonstrates just how many people adhered to consular authority right to the end. Many of those initially associated with the consuls, self-preservation trumping gratia, went over to Sulla, and some were rewarded handsomely. But the methods of the consuls were enough to inspire loyalty from more than a few senators and equites. ${ }^{161}$

The years of Sulla's absence presented something of a Hobson's choice for Rome's aristocrats: tolerate the (ordinarily) insufferable continuatio of Cinna and domination of political office by his friends, or fall in with the renegade in the east who looked likely to consign Rome to another civil war. Cicero captures the pain felt among the aristocracy in these years: recordor enim desperationes eorum, qui senes erant adulescente me ('for I remember their despair which the senior men felt during my youthful years'). ${ }^{162}$ Some fled; others appeased Cinna, before defecting; others remained loyal to the last.

The comitia between late 87 and late 83 were exceptional for their lack of competition and domination by a handful of individuals. Cinna's control of those chosen for high magistracy is clear: he rewarded and cultivated loyalty from great families to ensure a wide support base. But he monopolized the consulship, much to the (concealed) chagrin of his peers. Access to the summa laus was restricted to Cinna and whomever he desired as a colleague. The Cinnanum tempus, beginning in late 87 and ending in late 82, precipitated an original approach to popular politics. There was an advent of single-candidate elections: only candidates germane to the consuls' (or consul's) wishes were allowed to stand. Still, there are signs that there were attempts to maintain the semblance of normal republican government. With the running of elections, claims of popular sovereignty, albeit tenuous, could still be maintained. The People are a useful pretext.

While he lived, Cinna attempted to strike a balance between preserving this republican artifice and keeping himself in power, not least for his own safety. In many respects, his death brought about a radical change: the Senate became more vocal, and, as civil war approached once again, holding on to higher magistracies became critically important for Carbo and his

\footnotetext{
159 App. B Civ. 1.100.

${ }^{160}$ Cic. Dom. 79; Rosc. 141; Brut. 311. Cf. Douglas 1966, 223, on this 'stock phrase for Sulla's victory'.

161 Terror and intimidation would have convinced some to remain loyal at the very end: Marius ordered the murder of a number of senators in 82, which sent a clear message against defections. Sources in MRR 2.67.

162 Cic. Fam. 2.16.6.
} 
(and Cinna's former) amici. Comitia served as a tool to cement the authority and legitimacy of these men. But in the end it was brute force that proved decisive, with Sulla's violent return (eventually) restoring competitive elections to Rome. 
CONCLUSION

\section{ENFORCED TRANQUILLITY}

In a speech delivered in 81, Cicero celebrated the victorious return of Sulla: quae perfecta esse et suum cuique honorem et gradum redditum gaudeo ('I rejoice at the accomplishment of this [viz. dignitas at home, auctoritas abroad], at the restoration of everyone's honos and political rank'). ${ }^{1}$ The pro-Sullan tinge need not profoundly modify our understanding of Cicero's essential message. The period of Sulla's absence had witnessed the denial of political opportunity for many of Rome's great men. Doubtless many men expecting to be of the political class, disgruntled at the loss of political opportunity, were now hopeful of a return to competitive elections. ${ }^{2}$ The republic was recuperata, at least for those who loyally followed Sulla or defected at the right time.

Cinna took advantage of the turbulent political situation in the early 80 s to rise to a position of extraordinary power in 86 . He secured election to the consulship of 87 , thence assuming responsibility for the pressing issue of enfranchising Rome's new Italian citizens. Quite by chance, and after much bloodshed, this manoeuvre effected his political rise. His assumption of significant power as bis consul in 86 resulted in a transformation, if not a complete annulment, of the role of Rome's comitia. The comitia now elected just as many candidates as were presented to them, the procedure crucial to the process of assigning consular imperium to the newly elected officials. Subsequent elections followed a similar formula. Livy's Periochae is seemingly mistaken in its assertion that Cinna rose to his second consulship citra ulla comitia.

Modern scholars who attempt to defend Cinna's multiple consulships frequently hone in on Cicero's expression that this was triennium sine armis. Be that as maybe, this was a period of 'enforced tranquillity', before which political opponents had been terrorized into submission. ${ }^{3}$ Acknowledging the peculiarity of Cinna's repeated consulships is a crucial step in any discussion of the political perturbations of the 80s. In the often highly moralized debate surrounding the Cinnanum tempus, Marius' repeated consulships two decades earlier are sometimes cited in order to provide paradigmatic justifications for Cinna's continuatio. If

\footnotetext{
${ }^{1}$ Cic. Rosc. 136.

${ }^{2}$ On elections under Sulla's dictatorship, see, e.g., Vervaet 2004, esp. 47-8; Keaveney 2005, 136-7; Gabba 1967, $272-3$.

${ }^{3}$ Gruen 1968, 244.
} 
Marius could do it, so could Cinna, so the argument goes. What this study has demonstrated is the uniqueness of the political system between Sulla's departure to the east in 87 and his final victory in 82 .

Terrorism was certainly a factor in establishing Cinna's continuatio, but legalism and personal networks (through gratia and amicitia) assisted in consolidating his position of great influence in the Roman state. One can quite easily understand why there was little vocal opposition within Rome at this time. We need not assume that the legitimacy of the consuls was 'universally recognized'. From a human perspective, it is much more reasonable that the Roman Senate and People, after years of persistent conflict in and around Latium (especially the civil war between Octavius and Cinna), were softened up to any form of government provided that it guaranteed peace. ${ }^{5}$ Frankly, it seems to have guaranteed stability, albeit in the medium term. Plutarch's analysis of Caesar's dictatorship offers timeless insight into human

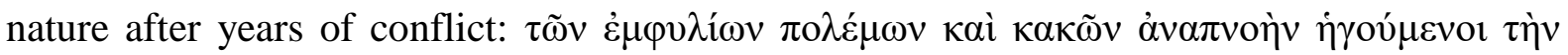

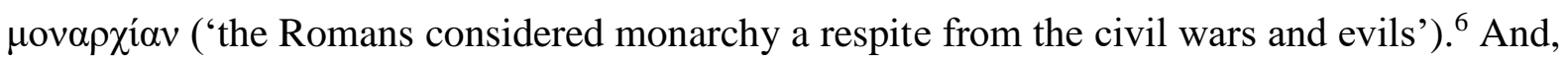
as Syme remarked on the nascence of the Augustan era: 'What Rome and Italy desired was a return, not to freedom - anything but that — but to civil and ordered government, in a word, to "normal conditions". ${ }^{7}$ Fear and fatigue of civil war soften people up to autocratic government. By fomenting an atmosphere of existential dread, Cinna found justification for his continuatio. Through comitia, he maintained its legitimacy.

Many of my conclusions in this survey are not, by any stretch, original. Robin Seager, writing in the Cambridge Ancient History, suggested that it is 'more likely that elections were held at which only two candidates were allowed to present themselves' during the Cinnanum tempus. ${ }^{8}$ This study has supplied further evidence to this effect. The multiple re-elections of $\mathrm{L}$. Cornelius Cinna and his colleagues offer insight into how an individual might acquire and consolidate power in a system deliberately constructed to prevent this very scenario. Intimidation and legalism go hand in glove.

\footnotetext{
${ }^{4}$ Badian 1962b, 55.

${ }^{5}$ So Hinard 2006, 254: 'le régime de terreur organisée avait [...] pour conséquence, sinon pour fin, de rendre tolérable au peuple romain d'un régime monarchique [sic].'

${ }^{6}$ Plut. Caes. 57.1.

${ }^{7}$ Syme 1939, 306.

${ }^{8}$ Seager 1994, 179.
} 


\section{BIBLIOGRAPHY}

Alföldi, A. 1976. 'The Giant Argus and a Miracle of Apollo in the Coin-Propaganda of Cinna and Carbo' in L. Bonfante and H. von Heintze (eds.), In Memoriam Otto J. Brendel. Mainz. 115-19.

Allen, Jr., W. 1953. 'Caesar's Regnum (Suet. Iul. 9.2)' TPAPhA 84: 227-36.

Astin, A.E. 1958. The Lex Annalis before Sulla. Brussels.

1962. "Professio" in the Abortive Election of 184 B.C.' Historia 11.2: 252-5.

1967. Scipio Aemilianus. Oxford.

Badian, E. 1955. 'The Date of Pompey’s First Triumph' Hermes 83.1: 107-18.

1957. 'Caepio and Norbanus' Historia 6.3: 318-46.

1958a. Foreign Clientelae. Oxford.

1958b. 'Notes on Provincial Governors from the Social War Down to Sulla's Victory'

PACA 1: 1-18.

1959. 'Caesar's Cursus and the Intervals between Offices' JRS 49.1-2: 81-9.

1962a. 'From the Gracchi to Sulla' Historia 11.2: 197-245.

1962b. 'Waiting for Sulla' JRS 52.1-2: 47-61.

1964a. 'Marius and the Nobles' The Durham University Journal 25.3: 141-54.

1964b. Studies in Greek and Roman History. Oxford.

1964c. 'Where Was Sisenna?' Athenaeum 42: 422-31.

1966. 'Notes on Provincia Gallia in the late Republic' in R. Chevallier (ed.), Mélanges d'archéologie et d'histoire. Paris. 901-18.

1969. 'Quaestiones Variae' Historia 18.4: 447-91.

1970. Titus Quinctius Flaminius: Philhellenism and Realpolitik. Cincinnati.

1976. 'Lucius Sulla: The Deadly Reformer' in A.J. Dunston (ed.), Essays on Roman Culture. Toronto. 35-74.

1984. 'The Death of Saturninus' Chiron 14: 101-47.

1990. 'The Consuls, 179-49 BC' Chiron 20: 371-413.

Balsdon, J.P.V.D. 1960. 'Auctoritas, Dignitas, Otium' CQ 10.1: 43-50.

1965. Review Article. JRS 55.1-2: 229-32.

Barlow, C.T. 1980. 'The Roman Government and the Roman Economy, 92-80 B.C.' AJPh 101.2: 202-19.

Bauman, R.A. 1973. 'The Hostis Declarations of 88 and 87 B.C.' Athenaeum 51: 270-93.

Beard, M. 1990. 'Priesthood in the Roman Republic' in M. Beard and J. North (eds.), Pagan Priests. London. 17-48.

Beck, H. 2005. Karriere und Hierarchie. Berlin.

Bennett, H. 1923. 'Cinna and His Times.' Dissertation. Chicago.

Betti, E. 1982. La crisi della repubblica e la genesi del principato in Roma. Rome.

Billows, R. 1989. 'Legal and Political Reform at Rome in the Early Second Century B.C.' Phoenix 43.2: 112-33.

2009. Julius Caesar. London and New York. 
Bingham, W.J. 1978. 'A Study of the Livian Periochae and Their Relation to Livy's Ab urbe condita.' Dissertation. Urbana.

Bispham, E. 2007. From Asculum to Actium. Oxford.

Blakeley, R. 2009. 'State Terrorism in the Social Sciences' in R. Jackson, E. Murphy, and S. Poynting (eds.), Contemporary State Terrorism. Abingdon. 12-27.

Bloch, G. and Carcopino, J. 1952. Des Gracques à Sulla. Paris.

Brennan, T.C. 1989. 'C. Aurelius Cotta, Praetor Iterum (CIL I² 610)' Athenaeum 67: 467-87. 2000. The Praetorship in the Roman Republic. 2 vols. Oxford.

Broughton, T.R.S. 1951-60. The Magistrates of the Roman Republic [MRR]. 3 vols. New York. 1991. 'Candidates Defeated in Roman Elections: Some Ancient Roman "Also-Rans"” TAPhS 81.4: 1-64.

Brunt, P.A. 1965. 'Italian Aims at the Time of the Social War' JRS 55.1-2: 90-109.

1966. 'The Roman Mob' $P$ \& $P$ 35: 3-27.

1971a. Italian Manpower 225 B.C.-A.D. 14. Oxford.

1971b. Social Conflicts in the Roman Republic. London.

1982. 'Nobilitas and Novitas' JRS 72: 1-17.

1988. The Fall of the Roman Republic and Related Essays. Oxford.

Bulst, C.M. 1964. "Cinnanum Tempus": A Reassessment of the "Dominatio Cinnae"" Historia 13.3: 307-37.

Butler, S. 2003. Review Article. CR 53.2: 414-15.

Cagniart, P.F. 1991. 'L. Cornelius Sulla in the Nineties: a Reassessment' Latomus 50.2: 285303.

Calabi, I. 1951. 'I commentarii di Silla come fonte storica' Memorie 3: 245-302.

Calvert, R.L. 1961. 'M. Claudius Marcellus cos. II 155 B.C.' Athenaeum 39: 11-23.

Carney, T.F. 1958. 'The Death of Marius' Acta Classica 1: 117-22.

1959. 'The Promagistracy at Rome 121-81 B.C.' Acta Classica 2: 72-7.

1960a. 'Cicero's Picture of Marius' Wiener Studien 73: 83-122.

1960b. 'The Death of Ancharius' Hermes 88.3: 382-4.

1960c. 'Plutarch's Style in the Marius' JHS 80: 24-31.

1962. 'The Picture of Marius in Valerius Maximus' RMPh 105.4: 289-337.

1970. A Biography of C. Marius. 2nd edn. Chicago.

Cerami, P. 2007. 'Sulla eleggibilità del presidente dei comizi elettorali' in Studi per Giovanni Nicosia. Vol. 2. Catania. 367-394.

Chaplin, J.D. 2010. 'The Livian Periochae and the Last Republican Writer' in M. Horster and C. Reitz (eds.), Condensing texts - condensed texts. Stuttgart. 451-67.

Corbellini, C. 1976. 'La presunta guerra tra Mario e Cinna e l'episodio dei Bardiei' Aevum 50.1-2: 154-6.

Cornell, T.J. 1995. The Beginnings of Rome. London and New York.

Cowan, E. 2015. 'Deceit in Appian' in K. Welch (ed.), Appian's Roman History. Swansea. 185-203.

Crawford, M.H. 1964. 'The Coinage of the Age of Sulla' Num. Chron. 4: 141-58.

Dart, C. 2010. 'Deceit and the Struggle for Roman Franchise in Italy' in A.J. Turner, J.H.K.O.

Chong-Gossard, and F.J. Vervaet (eds.), Private and Public Lies. Leiden. 91-105.

Degrassi, A. (ed.) 1947. Inscriptiones Italiae. Vol. 8. Rome. 
(ed.) 1954. Fasti Capitolini. Turin.

De Ligt, L. 2012. Peasants, Citizens and Soldiers. Cambridge.

De Martino, F. 1960. Storia della costituzione romana. Vol. 2. Naples.

Develin, R. 1978a. 'Scipio Aemilianus and the Consular Elections of 148 B.C.' Latomus 37.2: 484-8.

1978b. 'The Third Century Reform of the Comitia Centuriata' Athenaeum 56: 346-77.

1979. Patterns in Office-Holding 366-49 B.C. Brussels.

1985. The Practice of Politics at Rome 366-167 B.C. Brussels.

Douglas, A.E. 1966. M. Tulli Ciceronis Brutus. Oxford.

Dowling, M.B. 2000. 'The Clemency of Sulla' Historia 49.3: 303-40.

Drogula, F.K. 2007. 'Imperium, Potestas, and the Pomerium in the Roman Republic' Historia 56.4: 419-52.

2015. Commanders and Command in the Roman Republic and Early Empire. Chapel Hill.

Duplá, A. 2011. 'Consules populares' in H. Beck, A. Duplá, M. Jehne, and F. Pina Polo (eds.), Consuls and Res Publica. Cambridge. 279-98.

Dzino, D. 2010. Illyricum in Roman Politics, 229 BC-AD 68. Cambridge.

Earl, D. 1965. 'Appian B.C. 1, 14 and "Professio"' Historia 14.3: 325-33.

Epstein, D.F. 1987. Personal Enmity in Roman Politics 218-43 BC. London.

Evans, R.J. 1983. 'The Consulares and Praetorii in the Roman Senate at the Beginning of Sulla's Dictatorship' Athenaeum 66: 521-8.

1987. 'Metellus Numidicus and the Elections for 100 B.C.' Acta Classica 30: 65-80.

1991. 'Candidates and Competition in Consular Elections at Rome between 218 and 49

BC' Acta Classica 34: 111-36.

1995. 'Gaius Marius: A Political Biography.' Dissertation. Pretoria.

1997. 'The Augustan 'Purge' of the Senate and the Census of 86 BC' Acta Classica 40: 77-86.

Evans, R.J. and Kleijwegt, M. 1992. 'Did the Romans like Young Men?' ZPE 92: 181-95. Farney, G.D. 2004. 'Some More Roman Republican “Also-Rans"' Historia 53.2: 246-50.

Feig Vishnia, R. 1996. State, Society and Popular Leaders in Mid-Republican Rome 241-167 $B C$. London.

2012. Roman Elections in the Age of Cicero: Society, Government, and Voting. London.

Flower, H.I. 1996. Ancestor Masks and Aristocratic Power in Roman Culture. Oxford.

2006. The Art of Forgetting. Chapel Hill.

2010a. Roman Republics. Princeton.

2010b. 'Rome's First Civil War and the Fragility of Republican Political Culture' in B.W.

Breed, C. Damon and A. Rossi (eds.), Citizens of Discord. Oxford. 73-86.

Forsythe, G. 2005. A Critical History of Early Rome. Berkeley.

Frank, T. 1959. An Economic Survey of Ancient Rome. Vol. 1. Paterson.

Frei-Stolba, R. 1967. Untersuchungen zu den Wahlen in der Römischen Kaiserzeit. Zürich.

Frier, B.W. 1971. 'Sulla's Propaganda: The Collapse of the Cinnan Republic' AJPh 92.4: 585604.

Gabba, E. 1951. 'I senatori sillani' Athenaeum 29: 262-70.

1954. 'Le origini della Guerra Sociale e la vita politica romana dopo l'89 A.C.' Athenaeum 32: 41-114. 
1956. Appiano e la storia delle guerre civili. Florence.

1957. Review Article. Athenaeum 35: 368-70.

1967. Bellorum Civilium Liber Primus. Florence.

1972. 'Mario e Silla' ANRW 1.1: 764-805.

1994. 'Rome and Italy: The Social War' $C A H$, Vol. 2, IX: 104-28.

Gandhi, J. and Lust-Okar, E. 2009. 'Elections under Authoritarianism' Annual Review of Political Science 12: 403-22.

Gelzer, M. 1968. Caesar: Politician and Statesman. Cambridge, MA.

Giovannini, A. 2015. Les institutions de la République romaine des origines à la mort d'Auguste. Basel.

Golden, G.K. 2013. Crisis Management during the Roman Republic. Cambridge.

Gowing, A.M. 1992. The Triumviral Narratives of Appian and Cassius Dio. Ann Arbor.

Greenidge, A.H.J. 1901. Roman Public Life. London.

Grieve, L. 1985. 'The Reform of the Comitia Centuriata' Historia 34.3: 278-309.

Griffin, M. 1973. 'The Tribune C. Cornelius' JRS 63: 196-213.

Gruen, E.S. 1965. 'The Lex Varia' JRS 55.1-2: 59-73.

1966. 'The Dolabellae and Sulla' AJPh 87.4: 358-99.

1968. Roman Politics and the Criminal Courts, 149-78 B.C. Cambridge, MA.

1974. The Last Generation of the Roman Republic. Berkeley.

Hackl, U. 1982. Senat und Magistratur in Rom. Kallmünz.

Haimson Lushkov, A. Magistracy and the Historiography of the Roman Republic. Cambridge.

Hall, U. 1972. 'Appian, Plutarch, and the Tribunician Elections of 123 B.C.' Athenaeum 50: $3-35$.

Harris, W.V. 1971. Rome in Etruria and Umbria. Oxford.

Hellegouarc'h, J. 1972. Le vocabulaire latin des relations et des partis politiques sous la république. Paris.

Hermet, G. 1978. 'State-Controlled Elections' in Hermet, G., Rose, R., and Rouquié, A. (eds.), Elections without Choice. London. 1-18.

Hillman, T.P. 1996. 'Cinna, Strabo's Army, and Strabo's Death in 87 B.C.' Ant. Class. 65: 819.

1998. 'Notes on the Trial of Pompeius at Plutarch, Pomp. 4.1-6' Rh. Mus. 141.2: 176-93.

Hinard, F. 1985. Les Proscriptions de la Rome Républicaine. Rome.

2006. 'La terreur comme mode de gouvernement' in G. Urso (ed.), Terror et pavor: violenza, intimidazione, clandestinità nel mondo antico. Pisa. 247-64.

2008a. Appien : Histoire Romaine. Vol. 13. Paris.

2008b. Sullana Varia: Aux sources de la première guerre civile romaine. Paris.

Hodgson, L. 2017. Res Publica and the Roman Republic. Oxford.

Hölkeskamp, K.-J. 1987. Die Entstehung der Nobilität. Stuttgart.

1993. 'Conquest, Competition and Consensus: Roman Expansion in Italy and the Rise of the Nobilitas' Historia 42.1: 12-39.

2010. Reconstructing the Roman Republic. Princeton.

Hornblower, S., and Spawforth, A. (eds.). 2005. Oxford Classical Dictionary [OCD]. 3rd edn. Oxford.

Hurlet, F. 1993. La Dictature de Sylla: Monarchie ou magistrature républicaine. Brussels. 
Ihne, W. 1882. The History of Rome. Vol. 5. London.

Jahn, J. 1970. Interregnum und Wahldiktatur. Kallmünz.

Jal, P. 1984. Abrégés des livres de L'histoire romaine de Tite-Live. 2 vols. Paris.

Jehne, M. 1993. 'Geheime Abstimmung und Bindungswesen in der Römischen Republik' Historische Zeitschrift 257.3: 593-613.

2011. 'The Rise of the Consular as a Social Type in the Third and Second Centuries BC' in H. Beck, A. Duplá, M. Jehne and F. Pina Polo (eds.), Consuls and Res Publica. Cambridge. 211-31.

Jones, A.H.M. 1955. 'The Elections under Augustus' JRS 45.1-2: 9-21.

Katz, B.R. 1972. 'Cinna and Sulla: The Politics of Civil War.' Dissertation. Cambridge MA.

1976a. 'The Siege of Rome in 87 B.C.' CPh 71.4: 328-36.

1976b. 'Studies on the Period of Cinna and Sulla' Ant. Class. 45.2: 497-549.

1977. 'Caesar Strabo's Struggle for the Consulship - and more' Rh. Mus. 120.1: 45-63.

1979. 'The Selection of L. Cornelius Merula' Rh. Mus. 122.2: 162-6.

Keaveney, A. 1978. 'Pompeius Strabo's Second Consulship' CQ 28.1: 240-1.

1979. 'Sulla, Sulpicius and Caesar Strabo' Latomus 38.2: 451-60.

1982a. 'Sulla and Italy' Critica Storica 19: 499-544.

1982b. 'Young Pompey: 106-79 B.C.' Ant. Class. 51: 111-39.

1983a. 'Studies in the Dominatio Sullae' Klio 65: 185-208.

1983b. 'What Happened in 88?' Eirene 20: 53-86.

1984a. "“Civis Romanus Sum”' Critica Storica 21: 345-72.

1984b. 'Who Were the Sullani?' Klio 66: 114-50.

1987. Rome and the Unification of Italy. London and Sydney.

2005. Sulla: The Last Republican, 2nd edn. London.

Kendall, S.L. 2008. 'Romans, Allies, and the Struggle for the Roman Citizenship, 91-77 BCE' Dissertation. Lexington.

Kinsey, T.E. 1967. 'The Dates of the Pro Roscio Amerino and Pro Quinctio' Mnemosyne 20.1: 61-7.

Konrad, C.F. 1994. Plutarch's Sertorius: A Historical Commentary. Chapel Hill and London.

1996. 'Notes on Roman Also-Rans' in J. Linderski (ed.), Imperium Sine Fine: T. Robert S. Broughton and the Roman Republic. Stuttgart. 103-44.

Kraus, C.S. and Woodman, A.J. 1997. Latin Historians. Oxford.

Ładoń, Tomasz. 2013. 'Sulla's Peace Negotiations with Cinna's Faction in 85-83 B.C.' in Dariusz Słapek and Ireneusz Łuć (eds.), Lucius Cornelius Sulla: History and Tradition. Lublin. 91-102.

Lanzani, C. 1907. Storia interna di Roma negli anni 87-82 a. Chr. Turin.

1915. Mario e Silla. Catania.

Last, H. 1932. 'Sulla' CAH IX, 1st edn.: 261-312.

1944. "Cinnae Quater Consulis"” CR 58.1: 15-17.

Levi, M.A. 1928. La costituzione romana dai Gracchi a Giulio Cesare. Milan.

Levick, B. 1967. 'Imperial Control of the Elections under the Early Principate' Historia 16.2: 207-30.

1981. 'Professio' Athenaeum 59: 378-88.

1982. 'Sulla's March on Rome in 88 B.C.' Historia 31.4: 503-8. 
Levithan, J. 2013. Roman Siege Warfare. Ann Arbor.

Lewis, R.G. 2006. Asconius. Oxford.

Licandro, O. 1997. 'Candidature e accusa criminale: strumenti giuridici e lotta politica' Index 25: 447-71.

Linderski, J. 1966. 'Were Pompey and Crassus Elected in Absence to Their First Consulship?' in M.-L. Bernhard (ed.), Mélanges offerts à Kazimierz Michałowski. Warsaw. 523-6.

1986. 'The Augural Law' ANRW 2.16.3: 2146-2312.

2005. 'Religious Aspects: confarreatio' in K.A. Raaflaub (ed.), Social Struggles in Archaic Rome. Malden. 223-38.

Lintott, A.W. 1965. 'Trinundinum' $C Q$ 15.2: 281-5.

1971. 'The Tribunate of P. Sulpicius Rufus' $C Q 21.2$ : 442-53.

1976. 'Mithridatica' Historia 25.4: 489-91.

1990. 'Electoral Bribery in the Roman Republic' JRS 80: 1-16.

1994. 'The Crisis of the Republic: Sources and Source-Problems' CAH IX, 2nd edn: 165207.

1999. The Constitution of the Roman Republic. Oxford.

2008. Cicero as Evidence: A Historian's Companion. Oxford.

Lovano, M. 1996. 'Civil Strife, Factional Domination, and the Stability of Republican Rome, 88-82 B.C.' Dissertation. Los Angeles.

2002. The Age of Cinna: Crucible of Late Republican Rome. Stuttgart.

Luce, T.J. 1958. 'Appian's Exposition of the Roman Republican Constitution.' Dissertation. Princeton.

1961. 'Appian's Magisterial Terminology' $C P h$ 56.1: 21-8.

1968. 'Political Propaganda on Roman Republican Coins: circa 92-82 B.C.' AJA 72.1: 2539.

1970. 'Marius and the Mithridatic Command' Historia 19.2: 161-94.

Mackay, C.S. 2004. Ancient Rome: A Military and Political History. Cambridge.

2009. The Breakdown of the Roman Republic. Cambridge.

Magaloni, B., and Kricheli, R. 2010. 'Political Order and One-Party Rule' Annual Review of Political Science 13: 123-43.

Malcovati, H. (ed.) 1955. Oratorum Romanorum Fragmenta. 2nd edn. Turin.

Marino, R.E. 1974. 'Aspetti della politica interna di Silla' Atti della Accademia di Science, Lettere e Arti di Palermo 33: 361-529.

Markwitz, M. 2014. 'Untersuchungen zu Leben, Wirken und Karriere des Gaius Marius nach seinem sechsten Konsulat (100 v.Chr.-86 v.Chr.).' Dissertation. Vienna.

Marshall, B.A. 1985. A Historical Commentary on Asconius. Columbia.

Mastrocinque, A. 1999. Studi sulle guerre Mitridatiche. Stuttgart.

Mayor, A. 2010. The Poison King. Princeton.

McGing, B.C. 1986. The Foreign Policy of Mithridates VI Eupator King of Pontus. Leiden.

Meier, C. 1997. Res publica amissa. 3rd edn. Frankfurt.

Millar, F. 1984. 'The Political Character of the Classical Roman Republic, 200-151 B.C.' JRS 74: $1-19$.

1995. 'Popular Politics at Rome in the Late Republic' in I. Malkin and Z.W. Rubinsohn (eds.), Leaders and Masses in the Roman World. Leiden. 91-114. 
1998. The Crowd in Rome in the Late Republic. Ann Arbor.

2002. Rome, the Greek World, and the East. Vol. 1. Chapel Hill.

Mitchell, C., Stohl, M., Carleton, D., and Lopez G.A. 1986. 'State Terrorism' in Stohl, M., and Lopez, G.A. (eds.), Government Violence and Repression. New York. 1-26.

Mitchell, T.N. 1975. 'The Volte-Face of P. Sulpicius Rufus in 88 B.C.' Classical Philology 70.3: 197-204.

1979. Cicero: The Ascending Years. New Haven and London.

Mommsen, T. 1864. Römisches Forschungen. Vol. 1. Berlin.

1871. Römisches Staatsrecht. Vol. 1. Leipzig.

1901. The History of Rome. Translated by W.P. Dickson. Vol. 3. London.

Morstein-Marx, R. 1998. 'Publicity, Popularity and Patronage in the Commentariolum Petitionis' ClAnt 17.2: 259-88.

2004. Mass Oratory and Political Power in the Late Roman Republic. Cambridge.

2011. 'Consular Appeals to the Army in 88 and 87 ' in H. Beck, A. Duplá, M. Jehne and F. Pina Polo (eds.), Consuls and Res Publica. Cambridge. 259-78.

2015. 'Persuading the People in the Roman Participatory Context' in D. Hammer (ed.), A Companion to Greek Democracy and the Roman Republic. Malden. 294-309.

Mouritsen, H. 2001. Plebs and Politics in the Late Roman Republic. Cambridge.

2015. 'The Incongruence of Power: The Roman Constitution in Theory and Practice' in D. Hammer (ed.), A Companion to Greek Democracy and the Roman Republic. Malden. 146-63.

2017. Politics in the Roman Republic. Cambridge.

Niccolini, G. 1934. I fasti dei tribuni della plebe. Milan.

Nippel, W. 1995. Public Order in Ancient Rome. Cambridge.

North, J.A. 1990. 'Democratic Politics in Republican Rome' $P$ \& P 126: 3-21.

Oakley, S.P. 1998. A Commentary on Livy, Books VI-X. Oxford.

Passerini, A. 1971. Studi su Caio Mario. Milan.

Paterson, J. 1985. 'Politics in the Late Republic' in T.P. Wiseman (ed.), Roman Political Life: 90 B.C. - A.D. 69. Exeter.

Patterson, M.L. 1942. 'Rome's Choice of Magistrates during the Hannibalic War' TPAPhA 73: 319-40.

Paul, G.M. 1984. A Historical Commentary on Sallust's Bellum Jugurthinum. Liverpool.

Pelling, C. 2002. Plutarch and History. Swansea.

Peter, H. 1914. Historicorum romanorum reliquiae. Rev. ed. Leipzig.

Petković, Ž. 2008. 'Sulla and the Liburnian Campaign of Cinna' Aevum 82.1: 119-25.

Phillips, D.A. 1997. 'The Conspiracy of Egnatius Rufus and the Election of Suffect Consuls under Augustus' Historia 46.1: 103-12.

Pina Polo, F. 2011. The Consul at Rome: The Civil Functions of the Consuls in the Roman Republic. Cambridge.

Powell, J.G.F. 1990. 'The Tribune Sulpicius' Historia 39.4: 446-60.

Rafferty, D. 2011. 'Princeps Senatus' Melbourne Historical Journal 39.2: 1-22.

2017. 'Cisalpine Gaul as a Consular Province in the Late Republic' Historia 66.2: 147-72. Ramage, E.S. 1991. 'Sulla’s Propaganda' Klio 73: 93-121. 
Rampazzo, N. 2005. 'Professio tra regola ed eccezione nella storia elettorale della Roma repubblicana' in M. Garrido-Hory (ed.), Histoire, espaces et marges de l'antiquité, Vol. 4. Besançon. 93-130.

2008. Quasi Praetor Non Fuerit. Naples.

Ramsey, J.T. 1982. 'Cicero, pro Sulla 68 and Catiline's Candidacy in 66 BC' Harv. Stud. 86: 121-31.

2016. 'How and Why Was Pompey Made Sole Consul in 52 BC?' Historia 65: 298-324.

Rawson, E. 1979. 'L. Cornelius Sisenna and the Early First Century B.C.' CQ 29.2: 327-46.

1987. 'Sallust on the Eighties?' CQ 37.1: 163-80.

1994. 'Caesar: Civil War and Dictatorship' CAH IX, 2nd edn: 424-67.

Reams, L.E. 1993. 'Censorinus, Sulla, and Marius' Rh. Mus. 136.3-4: 281-8.

Richard, J.-C. 1964. 'La victoire de Marius' Mélanges d'Archéologie et d'Histoire 77: 68-86.

1979. 'Sur le Plébiscite ut liceret consules ambos plebeios creari' Historia 28.1: 65-75.

Ridley, R.T. 1981. 'The Extraordinary Commands of the Late Republic' Historia 30.3: 28097.

Rilinger, R. 1978. 'Die Ausbildung von Amtswechsel und Amtsfristen als Problem zwischen Machtbesitz und Machtgebrauch in der Mittleren Republik (342 bis 217 v. Chr.)' Chiron 8: 247-312.

Robb, M.A. 2010. Beyond Populares and Optimates: Political Language in the Late Republic. Stuttgart.

Rolin, G. 1979. 'La personnalité de Cicéron à l'âge de 26 ans' Ant. Class. 48.2: 559-82.

Rosenstein, N. 1990. Imperatores Victi: Military Defeat and Aristocratic Competition in the Middle and Late Republic. Berkeley.

1993. 'Competition and Crisis in Mid-Republican Rome' Phoenix 47.4: 313-38.

2012. Rome and the Mediterranean 290 to 146 BC. Edinburgh.

Rotondi, G. 1922. Leges Publicae Populi Romani. Hildesheim.

Rowland, Jr., R.J. 1966. 'Numismatic Propaganda under Cinna' TAPhA 97: 407-19.

Sage, M.M. 1980. 'The De Viris Illustribus: Authorship and Date' Hermes 108.1: 83-100.

Salmon, E.T. 1964. 'Sulla Redux' Athenaeum 42: 60-79.

1967. Samnium and the Samnites. Cambridge.

1982. The Making of Roman Italy. Ithaca.

Santangelo, F. 2007. Sulla, the Elites and the Empire. Leiden.

2013. Divination, Prediction and the End of the Roman Republic. Cambridge.

Sartori, F. 1973. 'Cinna e gli schiavi' in Actes du colloque 1971 sur l'esclavage. Paris. 15169.

Scanlon, T.F. 1987. Spes Frustrata: A Reading of Sallust. Heidelberg.

Schedler, A. 2013. The Politics of Uncertainty. Oxford.

Scullard, H.H. 1960. 'Scipio Aemilianus and Roman Politics' JRS 50.1-2: 59-74.

1973. Roman Politics: 220-150 B.C., 2nd edn. Oxford.

1982. From the Gracchi to Nero, 5th edn. London and New York.

Seager, R. 1977. “"Populares” in Livy and the Livian Tradition' CQ 27.2: 377-90.

1994. 'Sulla' CAH, IX: 165-207.

2002. Pompey the Great. 2nd edn. Oxford.

Shatzman, I. 1975. Senatorial Wealth and Roman Politics. Brussels. 
Sherwin, W.K. 1969. 'Livy and the De viris illustribus' Philologus 113: 298-301.

Sherwin-White, A.N. 1956. 'Violence in Roman Politics' JRS 46.1-2: 1-9.

1973. The Roman Citizenship, 2nd edn. Oxford.

Smyth, H.W. 1956. A Greek Grammar, rev. ed. Cambridge MA.

Stadter, P.A. 2014. Plutarch and His Roman Readers. Oxford.

Stangl, T. 1909. Pseudoasconiana. Paderborn.

Staveley, E.S. 1954. 'The Conduct of Elections during an Interregnum' Historia 3.2: 193-211.

1972. Greek and Roman Voting and Elections. London.

Steed, K.L.S. 2008. 'Memory and Leadership in the Late Roman Republic.' Dissertation. Ann Arbor.

Steel, C.E.W. 2013. The End of the Roman Republic, 146 to 44 BC: Conquest and Crisis. Edinburgh.

2014a. 'Rethinking Sulla: The Case of the Roman Senate' CQ 64.2: 657-68.

2014b. 'The Roman Senate and the Post-Sullan Res Publica' Historia 63.3: 323-39.

Stevenson, T. 2015. Julius Caesar and the Transformation of the Roman Republic. Abingdon.

Stewart, R. 2010. Public Office in Early Rome. Ann Arbor.

Stout, S.E. 1918. 'Rotation in Office in the Roman Republic' CJ 13.6: 429-35.

Straumann, B. 2016. Crisis and Constitutionalism. Oxford.

Sumi, G.S. 2005. Ceremony and Power. Ann Arbor.

Sumner, G.V. 1973. The Orators in Cicero's Brutus: Prosopography and Chronology. Toronto.

1975. 'Elections at Rome in 217 B.C.' Phoenix 29.3: 250-9.

Suolahti, J. 1963. The Roman Censors. Helsinki.

Sydenham, E.A. 1952. The Coinage of the Roman Republic [CRR]. London.

Syme, R. 1939. The Roman Revolution. Oxford.

Taglialatela Scafati, M. 1995. 'Cinna e la "confarreatio"' in G. Franciosi (ed.), Ricerche sulla organizzazione gentilizia romana. Vol. 3. Naples. 71-83.

Tansey, P. 2000. 'The Princeps Senatus in the Last Decades of the Republic' Chiron 30: 1530.

2003. 'The Death of M. Aemilius Scaurus' Historia 52.3: 378-83.

Tatum, W.J. 1999. The Patrician Tribune: Publius Clodius Pulcher. Chapel Hill and London. 2002. 'Q. Cicero, Commentariolum Petitionis 33' CQ 52.1: 394-8.

2003/04. Review Article. CJ 99.2: 203-16.

2007. 'Alterum est tamen boni viri, alterum boni petitoris: The Good Man Canvasses'

Phoenix 61.1-2: 109-35.

2008. Always I Am Caesar. Malden.

2009. 'Roman Democracy?' in R.K. Balot (ed.), A Companion to Greek and Roman Political Thought. Oxford. 214-27.

2011. 'The Late Republic: Autobiographies and Memoirs in the Age of the Civil Wars' in

G. Marasco (ed.), Political Autobiographies and Memoirs in Antiquity. Leiden. 16187.

2013. 'Campaign Rhetoric' in C. Steel and H. van der Blom (eds.), Community and Communication: Oratory and Politics in Republican Rome. Oxford. 133-50. 
2015. 'The Practice of Politics and the Unpredictable Dynamics of Clout in the Roman Republic' in D. Hammer (ed.), A Companion to Greek Democracy and the Roman Republic. Malden. 257-73.

Forthcoming. '88 B.C.' in J. Prag and A. Valentina (eds.), A Companion to the Political Culture of the Roman Republic. Malden.

Taylor, L.R. 1941. 'Caesar's Early Career' CPh 36.2: 113-32.

1949. Party Politics in the Age of Caesar. Berkeley.

1960. The Voting Districts of the Roman Republic. Rome.

1966. Roman Voting Assemblies. Ann Arbor.

Tondo, S. 1993. Profilo di storia costituzionale romana. Vol. 2. Milan.

Twyman, B.L. 1974. 'The Date of Sulla's Abdication and the Chronology of the First Book of Appian's Civil Wars' Athenaeum 54: 77-97, 271-95.

Urso, G. 2016. 'Cassius Dio's Sulla' in C.H. Lange and J.M. Madsen (eds.), Cassius Dio: Greek Intellectual and Roman Politician. Leiden. 13-32.

Valgiglio, E. 1956a. Silla e la crisi repubblicana. Florence.

1956b. Vita di Mario. Florence.

Van Ooteghem, J. 1964. Caius Marius. Brussels.

Vervaet, F.J. 2004. 'The Lex Valeria and Sulla's Empowerment as Dictator (82-79 BCE)' Cahiers du CGG 15: 37-84.

2014. The High Command in the Roman Republic. Stuttgart.

Wiseman, T.P. 1971. New Men in the Roman Senate 139 B.C.-A.D. 14. Oxford.

2009. Remembering the Roman People: Essays on Late-Republican Politics and Literature. Oxford.

Weinrib, E.J. 1968. 'The Prosecution of Roman Magistrates' Classical Association of Canada 22.1: $32-56$.

Welch, K.E. 1990. 'The Praefectura Urbis of 45 B.C. and the Ambitions of L. Cornelius Balbus' Antichthon 24: 53-69.

Westall, R. 2015. 'The Sources for the Civil Wars of Appian of Alexandria' in K. Welch (ed.), Appian's Roman History. Swansea. 125-68.

Yakobson, A. 1992. 'Petitio et Largitio: Popular Participation in the Centuriate Assembly of the Late Republic' JRS 82: 32-52.

1995. 'Secret Ballot and Its Effects in the Late Roman Republic' Hermes 123.4: 426-42.

1999. Elections and Electioneering in Rome. Stuttgart.

2006. 'Il popolo romano, il sistema e l'«élite»: il dibattito continua' Studi storici 47.2: 37793.

2010. 'Traditional Political Culture and the People's Role in the Roman Republic' Historia 59.3: $282-302$.

Yavetz, Z. 1982. Julius Caesar and His Public Image. London.

Ziolkowski, A. 1993. 'Urbs direpta or How the Romans Sacked Cities' in J. Rich and G.

Shipley (eds.), War and Society in the Roman World. London. 69-91.

Zorzetti, N. (ed.) 1982. Iulii Exuperantii Opusculum. Leipzig. 